GIACOMO LUIZ MARIA OLIVEIRA GREZZANA

\title{
A NATUREZA JURÍDICA DA CLÁUSULA DE DECLARAÇÕES E GARANTIAS EM ALIENAÇÃO DE PARTICIPAÇÃO SOCIETÁRIA
}

\author{
Dissertação de Mestrado \\ Orientador: Prof. Associado Erasmo Valladão Azevedo e Novaes França
}

UNIVERSIDADE DE SÃO PAULO

FACULDADE DE DIREITO

São Paulo/SP

2019 

GIACOMO LUIZ MARIA OLIVEIRA GREZZANA

\title{
A NATUREZA JURÍDICA DA CLÁUSULA DE DECLARAÇÕES E GARANTIAS EM ALIENAÇÃO DE PARTICIPAÇÃO SOCIETÁRIA
}

\begin{abstract}
Dissertação apresentada à Banca Examinadora do Programa de Pós-graduação em Direito, da Faculdade de Direito da Universidade de São Paulo, como exigência parcial para obtenção do título de Mestre em Direito, na área de concentração Direito Comercial, sob orientação do Prof. Associado Erasmo Valladão Azevedo e Novaes França.
\end{abstract}

UNIVERSIDADE DE SÃO PAULO

FACULDADE DE DIREITO

São Paulo/SP

2019 
Serviço de Processos Técnicos da Biblioteca da Faculdade de Direito da Universidade de São Paulo

Grezzana, Giacomo Luiz Maria Oliveira

A natureza jurídica da cláusula de declarações e garantias em alienação de participação societária / Giacomo Luiz Maria Oliveira Grezzana. -- São Paulo, 2019.

513 p. ; $30 \mathrm{~cm}$.

Dissertação (Mestrado) - Programa de Pós-Graduação em Direito, Faculdade de Direito, Universidade de São Paulo, São Paulo, 2019.

Orientador: Erasmo Valladão Azevedo e Novaes França. 


\title{
A NATUREZA JURÍDICA DA CLÁUSULA DE DECLARAÇÕES E GARANTIAS EM ALIENAÇÃO DE PARTICIPAÇÃO SOCIETÁRIA
}

\begin{abstract}
Dissertação apresentada à Banca Examinadora do Programa de Pós-graduação em Direito, da Faculdade de Direito da Universidade de São Paulo, como exigência parcial para obtenção do título de Mestre em Direito, na área de concentração Direito Comercial.
\end{abstract}

Ata $n$.

Aprovado em

BANCA EXAMINADORA

Prof. Associado Erasmo Valladão Azevedo e Novaes França (orientador)

Examinador

Examinador

Examinador

São Paulo 

A todos que pacientemente ouviram os argumentos desta dissertação 



\section{RESUMO}

Autor: Giacomo Luiz Maria Oliveira Grezzana. Título: A natureza jurídica da cláusula de declarações e garantias em alienação de participação societária. Data: 15.01.2019. Número de páginas: 513 p. Mestrado - Faculdade de Direito, Universidade de São Paulo, São Paulo, data: 15.01.2019.

O trabalho inicia buscando compreender a função exercida pela cláusula de declarações e garantias nos sistemas de common law inglês e norte-americano para, a partir de sua função, identificar a natureza jurídica da cláusula no direito brasileiro. Na primeira parte do trabalho, procede-se a uma investigação acerca do tipo e dos índices de tipo da cláusula de declarações e garantias, concluindo-se pela tipicidade social da cláusula com função assecuratória em operações de alienação de participação societária, mas com a possibilidade de absorver funções conformativa, informativa e probatória que não são socialmente típicas nesse tipo de operação. Na segunda parte do trabalho, com base na identificação do tipo declarações e garantias, a dissertação analisa o regime jurídico aplicável à cláusula socialmente típica, isto é, enquanto obrigação de garantia. $\mathrm{Na}$ sequência, abordam-se as funções atípicas da cláusula e seu regime jurídico - obrigação de dar, responsabilidade pré-contratual, erro, dolo e vícios redibitórios e evicção -, indicando também como as partes podem formatar a cláusula de declarações e garantias para assumir uma outra função. $\mathrm{O}$ trabalho também aborda o processo de auditoria prévia na sociedade para aquisição das ações ou quotas (due diligence), seu modo de realização e implicações sobre as obrigações das partes.

Palavras-chave: declarações; garantias; declarações e garantias; representações; representações e garantias; representations; warranties; representations and warranties; sociedades; venda; compra; alienação; participação societária; obrigação de garantia; obrigação de dar; pré-contratual; informação; erro; dolo; vícios redibitórios; evicção; due diligence; auditoria; comprador; vendedor. 



\begin{abstract}
Author: Giacomo Luiz Maria Oliveira Grezzana. Title: The legal character of representations and warranties in share acquisition transactions. Date: 01.15.2019. Number of pages: 513. Master`s degree - Law School, University of São Paulo, São Paulo, 01.15.2019.
\end{abstract}

This master thesis starts with the understanding of the functions carried out by the clause of representations and warranties in the English and US common law systems so as to be able to identify its corresponding legal nature under Brazilian Law. In its first part, this thesis investigates the contractual kind of representations and warranties, concluding that it discharges a socially typical assecuratory function in transactions involving transfer of shares and equity interest, but it keeps open the possibility of discharging other nonsocially typical functions such as to conform, to inform and to make proof of information gathered in the pre-contractual phase. In the second part of the thesis, based on the identified contractual type of representations and warranties, the legal regime applicable to the socially typical clause is analyzed, which is an obligation to guarantee the other party against certain risks. The thesis also deals with the atypical functions of representations and warranties and their legal regimes - obligation to give, pre-contractual liability, misrepresentation and implied warranties (vícios redibitórios e evicção) - also indicating how parties can shape the clause of representations and warranties to assume such atypical functions. This thesis also addresses the process of due diligence for acquisition of shares and equity interest, as well as its execution and effects thereof on parties' obligations.

Keywords: warranties; representations; representations and warranties; companies; sale; purchase; acquisition; shares; stock; equity interest; obligation to guarantee; obligation to give; pre-contractual; information; misrepresentation; due diligence; audit; buyer; seller. 



\section{ZUSAMMENFASUNG}

Verfasser: Giacomo Luiz Maria Oliveira Grezzana. Titel: Die Rechtsnatur der "Representations and Warranties"-Klausel in Unternehmenskaufverträge. Datum: 15.01.2019. Seitenzahl: 513 S. Masterarbeit - juristische Fakultät der Universität von São Paulo, São Paulo, datum 15.01.2019.

Die Masterarbeit untersucht die Aufgaben der "Representations and Warranties" -Klausel in den common law'schen Systemen und abzielt, anhand solcher Aufgaben, die Rechtsnatur der Klausel in brasilianischem Recht festzustellen. Im ersten Teil der Masterarbeit wird den Vertragstypus der Representations and Warranties ermittelt, mit der Schulssfolgerung, dass diese Klausel in Unternehmenskäufen einen sozialen Typus darstellt, wenn sie durch die Parteien als eine Garantievereinbarung aufgebaut ist, also wenn sie eine Garantiefunktion wiederspiegelt. Trotzdem gibt es die Möglichkeit andere Funktionen auszuüben, nämlich Gestaltungs-, Informations- und Beweisfunktionen, die nicht ganz typisch in solchen Operationen sind. Im zweiten Teil wertet die Arbeit die durch die sozialtypische Garantiefunktion geprägte Rechtsnatur der Klausel als Garantievereinbarung aus und führt die entsprechenden rechtlichen Rahmenbedingungen aus. Die atypischen Funktionen werden auch ausgewertet, sowie die Rechtsinstituten, die jede solcher Funktionen entsprechen: Stückschuld, Haftung aus culpa in contrahendo, Irrtum, Täuschung, Rechtsmängel und Sachmängel. Wie die Parteien solche Funktionen im Vertrag gestalten können ist auch verdeutlicht. Der Due Diligence-Verfahren wird angesprochen, als auch seine Implikationen für die Pflichten der Parteien.

Stichwörter: Garantien; Garantievereinbarung; selbständige Garantieversprechen; Zuscherung einer Eigenschaft; Beschaffenheitsvereinbarung; Representations; Warranties, Representations and Warranties; Verkauf; Kauf; Beteiligungskauf; Stückkauf; culpa in contrahendo; Information; Irrtum; Täuschung; Sachmängel; Rechtsmängel; Due Diligence; Unternehmenskauf 



\section{RÉSUMÉ}

Auteur: Giacomo Luiz Maria Oliveira Grezzana. Titre: La nature juridique des déclarations $\mathrm{du}$ garant (representations and warranties) dans les cessions de droits sociaux. Date: 15.01.2019. Pages: 513 p. Thèse pour le degré de Master - Faculté de droit, Université de São Paulo, São Paulo, date 15.01.2019.

La these commence en examinant la fonction exercée par la clause contenant les déclarations du garant (representations and warranties) dans les systèmes de common law anglais e nord-américain, avec le but de, à partir de sa fonction, identifier sa nature juridique dans le droit brésilien. En la première partie du travail, on recherche le typ e les caractères typiques de la clause de déclarations du garant et on conclut que cette clause a une typicité sociale dans les cessions de droit sociaux quand elle exerce une fonction d'assurance, mais elle a aussi la possibilité d'absorber des fonctions conformative, informative e d'épreuve, lesquelles ne sont pas typiques dans l'opération susvisée. En la deuxième partie, le travail fait une analyse le régime juridique applicable à la clause socialement typique, ça veut dire, comme si le garant s'engage ver une obligation de garantie. Ensuite, on adresse les fonctions atypiques de ces déclarations e son régime juridique correspondant - obligation de délivrance conforme, responsabilité précontractuelle, erreur, dol, vices cachés e éviction - en indiquant comme les parties puissent déssiner la clause de déclarations du garant pour qu'elle joue la fonction déterminée. La thèse aborde néanmoins les audits préalables à l'acquisition des droits sociaux (due diligence), son mode de réalisation e ses implications pour les obligations des parties.

Mots-clés : déclarations; garanties; déclarations du garant; representations; warranties; déclaration de sincérité; garantie de passif; garantie d'actif; garantie de valeur; societé; droits sociaux; vente; obligation de garantie; délivrance conforme; pré-contractuelle; information; erreur; dol; vices cachés; éviction; due diligence; audit préalable; acheteur; vendeur 



\section{RIASSUNTO}

Autore: Giacomo Luiz Maria Oliveira Grezzana. Titolo: La natura giuridica delle clausole di rappresentazioni e garanzie nella alienazione di partecipazioni societarie. Data: 15.01.2019. Pagine: 513 p. Master - Facoltà di Giurisprudenza, Università di San Paolo, San Paolo, data: 15.01.2019.

La tese di master cerca di comprendere la funzione della clausola di rappresentazioni e garanzie nei sistemi di common law inglese e americano così da, sulla stregua delle funzioni che queste esercitano in quei sistemi, potere fare l'identificazione della sua natura giuridica nel diritto brasiliano. Nella prima parte della tese, si fà un'investigazione sul tipo contrattuale e sulle caratteristiche della clausola di rappresentazioni e garanzie, concludendosi per la sua tipicità sociale con funzione di assicurazione nei negozi di alienazione di partecipazioni societarie. Però si conclude anche che la clausole ha la possibilità di assorbere altre funzioni di conformazione, di informazione e di prova che non sono, tuttavia, socialmente tipiche in questo tipo di operazione. Nella seconda parte, con riguardo alle funzioni individuate, la tese analizza il regime giuridico applicable alla detta clausola in quanto funzione socialmente tipica, ossia, comme obbligo di garanzia, e aboorda anche i regimi dettati dalle funzioni non tipiche - obbligo di dare, responsabilità precontrattuale, errore, dolo, vizi redibitori ed evizione - indicando comme possono le parti adattare la clausola di rappresentazioni e garanzie per compiere ciascuna di queste funzioni. La tese abborda anche la verifica dei cespiti aziendali prima dell'acquisizione (due diligence), bensí il suo modo di realizzazione e le implicazioni per le obblighi delle parti.

Parole-chiave : dichiarazioni ; garanzie ; rappresentazioni ; rappresentazioni e garanzie ; representations and warranties ; società ; vendita ; alienazione ; partecipazione societaria ; obbligo di garanzia ; obbligo di dare ; precontrattuale ; informazione ; errore ; dolo ; vizi redibitori ; evizione ; due diligence ; compratore ; venditore ; business warranties ; legal warranties 



\section{SUMÁRIO}

SUMÁRIO

INTRODUÇÃO: COLOCAÇÃO DO PROBLEMA..........................................................23

1. Preliminares ...................................................................................................................................23

2. As condições de entorno do direito contratual no common law....................................25

2.1. Análise objetiva dos termos que formam o conteúdo contratual ........................26

2.2. Ausência de regulação dos tipos contratuais na lei .............................................27

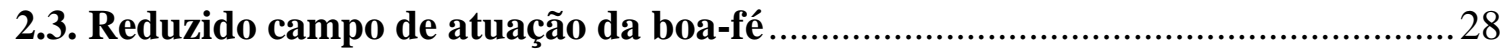

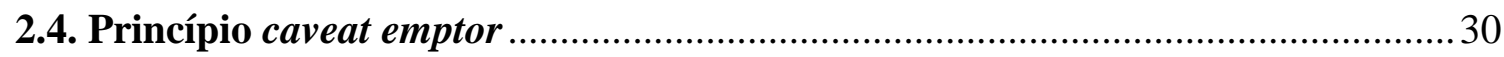

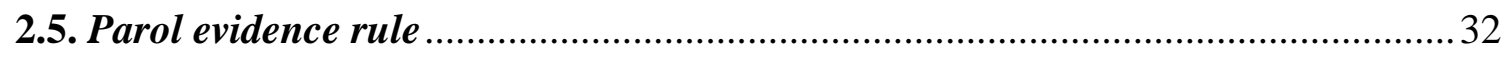

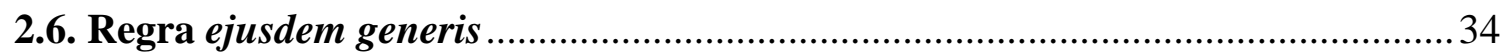

3. A misrepresentation …….....................................................................................................36

4. A tipologia das cláusulas contratuais no common law …….............................................. 45

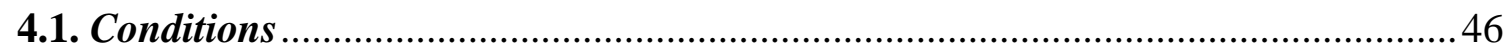

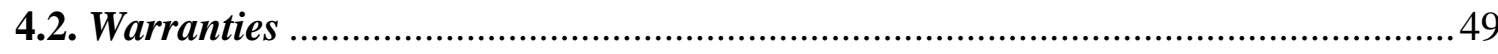

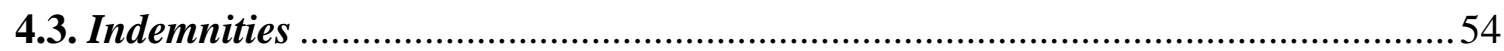

5. A cláusula de declarações e garantias .............................................................................58

6. Exposição do problema .................................................................................................................63

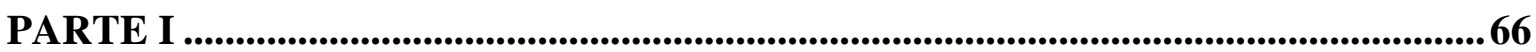

1. Análise tipológica da cláusula de declarações e garantias .............................................66

2. Funções da cláusula de declarações e garantias...........................................................73

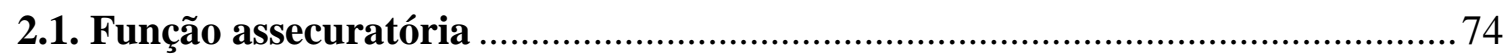

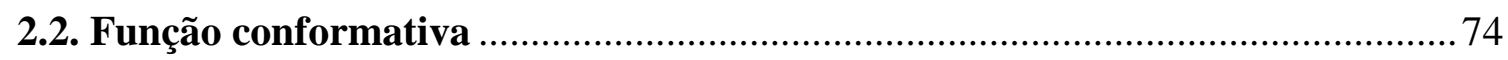

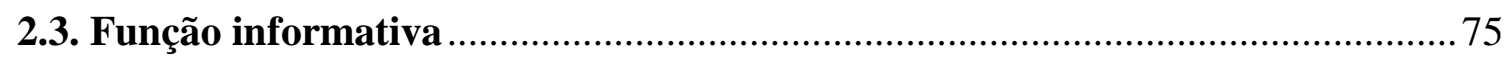

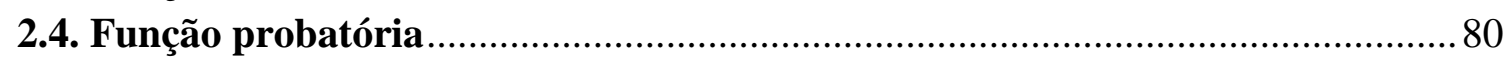

3. O enquadramento tipológico da cláusula de declarações e garantias..........................83

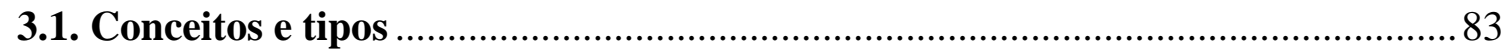

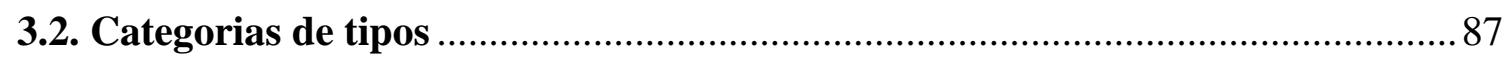

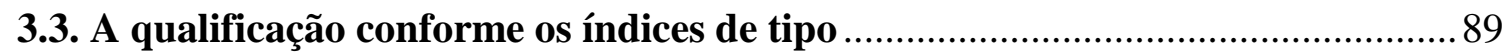

3.4. O subtipo declarações e garantias em alienações de participação societária ....96

4. Classificação das declarações e garantias em alienação de participação societária

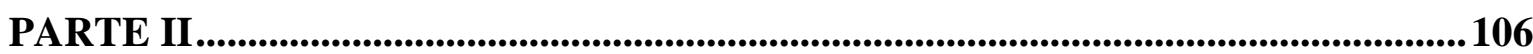

1. Proposição...............................................................................................................................106

2. A alienação de participação societária nos planos obrigacional e real .....................106

3. A natureza jurídica das ações ou quotas .....................................................................110

4. Transferência de participação societária como cessão de posição contratual ........115

5. Distinção entre objeto da alienação de participação societária e as vicissitudes da sociedade-alvo..............................................................................................................................120 
PARTE III

1. Panorama sobre a natureza jurídica da cláusula de declarações e garantias ......... 140

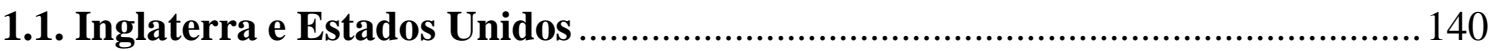

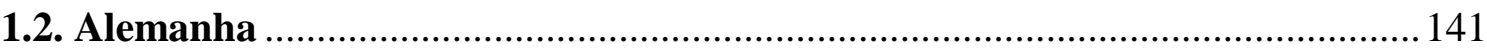

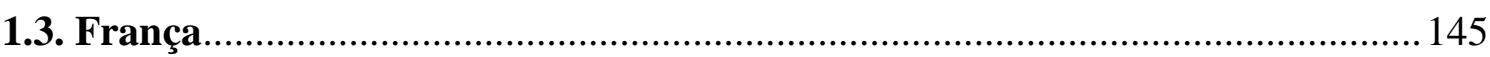

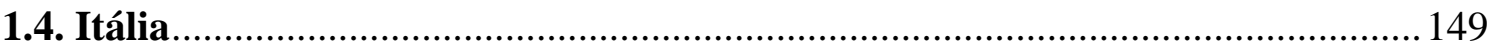

1.5. Panorama do direito brasileiro e exposição da tese defendida ......................... 155

2. A qualificação das declarações e garantias como obrigação de garantia ................162

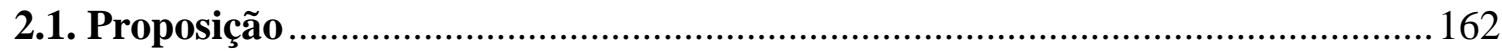

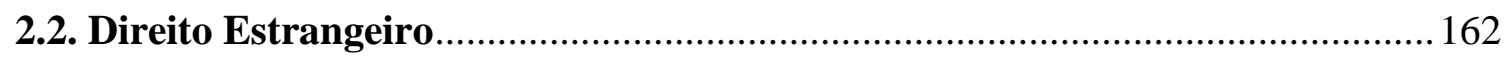

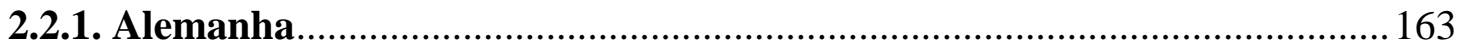

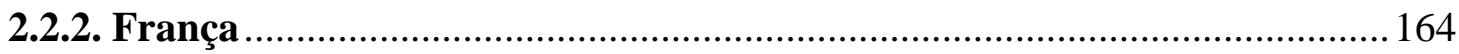

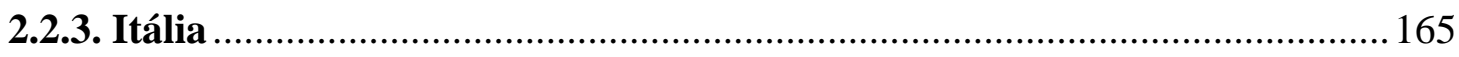

2.3. A possibilidade de qualificar as declarações e garantias como obrigação de

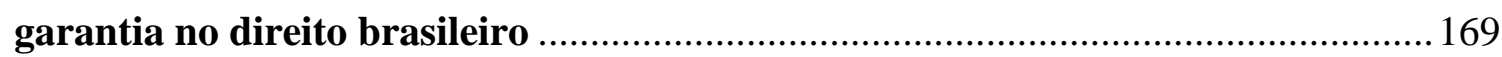

2.3.1. Elementos da obrigação de garantia: a garantia .................................... 171

2.3.2. Elementos da obrigação de garantia: o interesse protegido ....................... 174

2.3.3. Elementos da obrigação de garantia: o risco ........................................... 178

2.4. Estrutura da cláusula de declarações e garantias como obrigação de garantia

2.4.1. Prazo de garantia

2.4.2. Quem presta a garantia....................................................................... 191

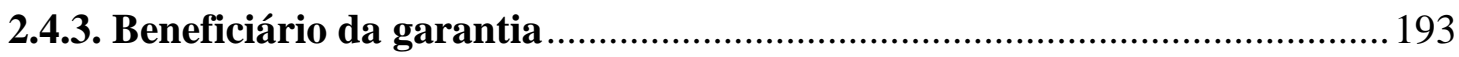

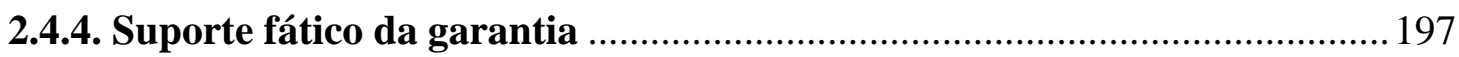

2.4.5. As consequências da falsidade das declarações e garantias.......................202

2.4.6. Consequências em espécie da falsidade de declarações e garantias:

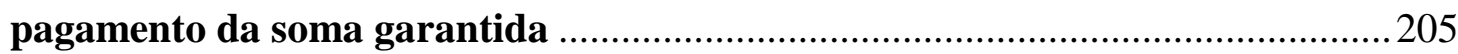

2.4.7. Consequências em espécie da falsidade de declarações e garantias: redução do preço

2.4.8. Consequências em espécie da falsidade de declarações e garantias: desfazimento do negócio.

2.4.9. Consequências em espécie da falsidade de declarações e garantias: sanação in natura do risco

2.4.10. Desnecessidade da classificação legal warranties e business warranties ... 215

3. A qualificação das declarações e garantias como obrigação de dar.

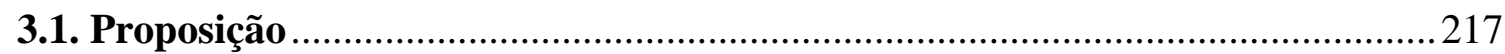

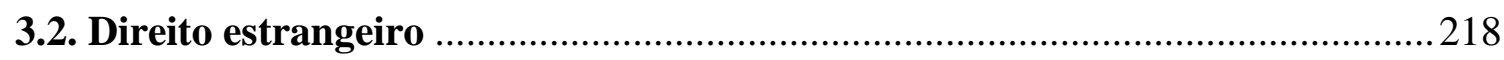

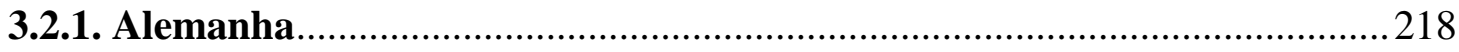

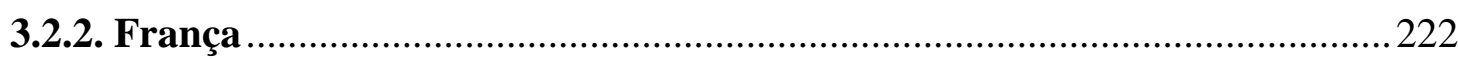

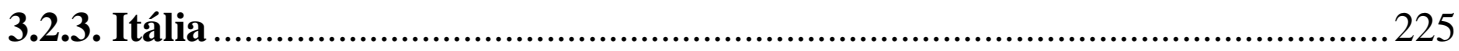

3.3. As declarações e garantias como obrigação dar no direito brasileiro...............229

3.4. A estrutura das declarações e garantias como qualificadoras da obrigação de dar. 
3.4.1. Consequências da violação a declarações e garantias: cumprimento específico.

3.4.2. Consequências da violação a declarações e garantias: indenização ...........246

3.4.3. Consequências da violação a declarações e garantias: resolução do contrato

4. Declarações e garantias e responsabilidade pré-contatual .....................................261

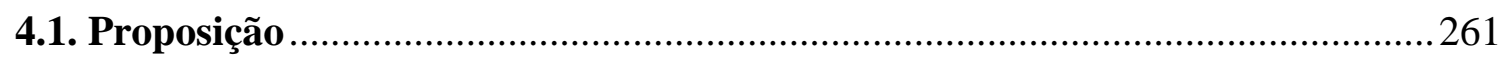

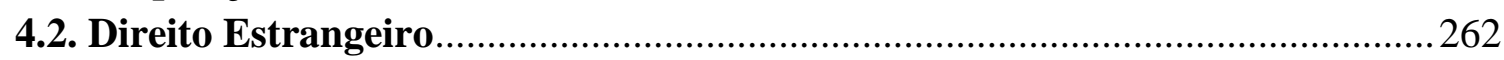

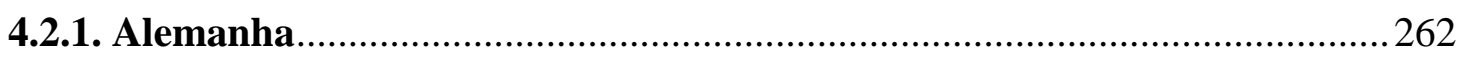

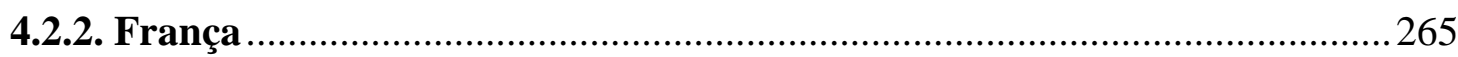

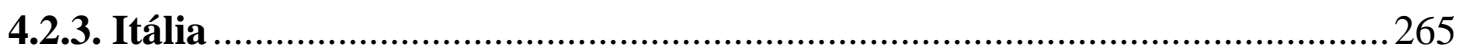

4.3. O surgimento de um dever de informar na fase de negociações em alienação de

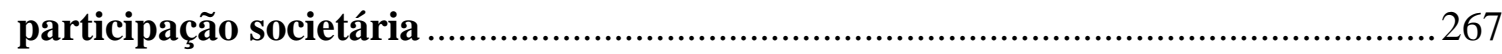

4.3.1. A estrutura do dever de informar .............................................................. 273

4.3.1.1. Desconhecimento da informação pelo credor da informação..............2273

4.3.1.2. Conhecimento da informação pelo devedor da informação ................2276

4.3.1.3. Legitimidade do desconhecimento da informação: ônus de

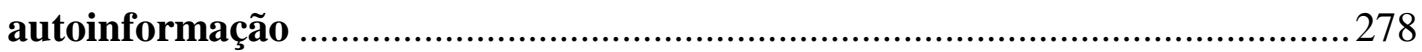

4.3.1.4. Legitimidade do desconhecimento da informação: perguntas e respostas

4.3.1.5. Legitimidade do desconhecimento da informação: relação de confiança

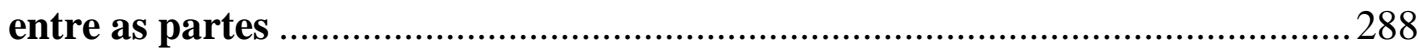

4.3.2. Outros topoi aplicáveis à alienação de participação societária ...................20 290

4.3.2.1. Distribuição do risco informacional entre as partes ............................290

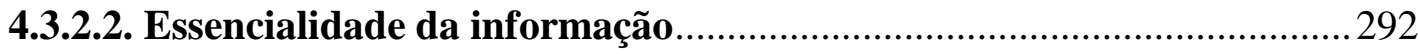

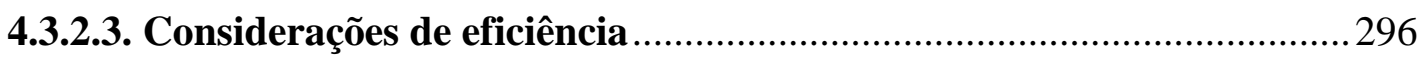

4.4. Conteúdo e extensão do dever de informar .................................................... 300

4.5. Dever pré-contratual de informar em alienação de participação societária e due

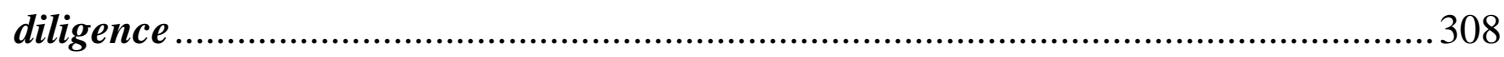

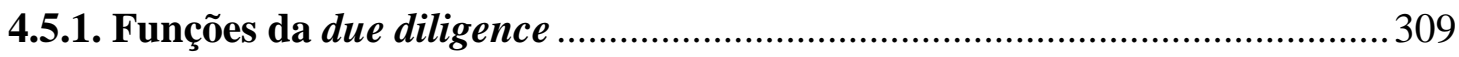

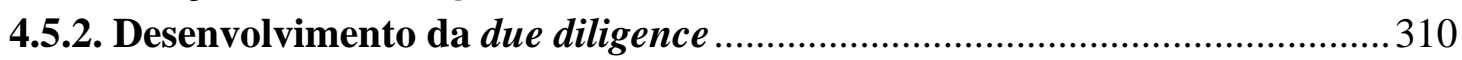

4.5.3. Due diligence, diligência e ônus de autoinformação .................................... 312

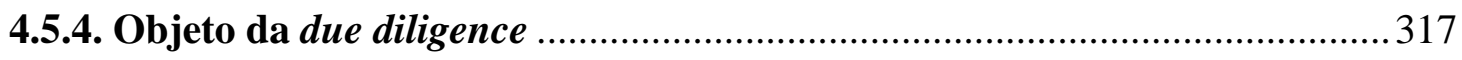

4.6. Responsabilidade por violação a deveres pré-contratuais de informar ............319

4.6.1. Consequências jurídicas da violação a dever de informar .........................320

4.6.2. Fixação do dano sofrido pela falha no dever de informar ...........................327

4.7. Dever de informar e cláusula de declarações e garantias ..................................332

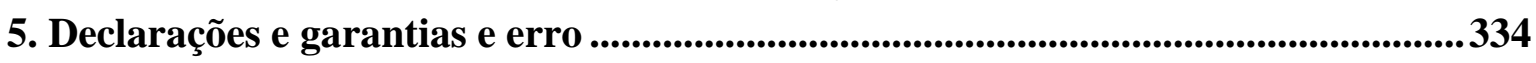

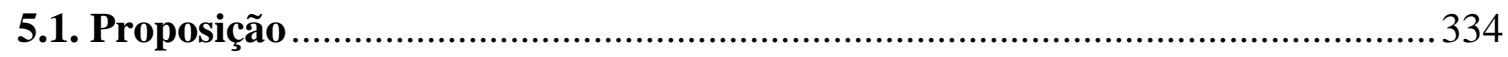

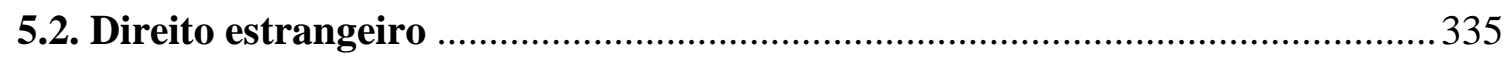

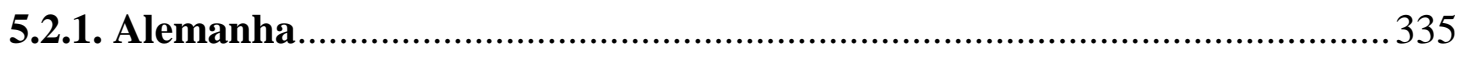

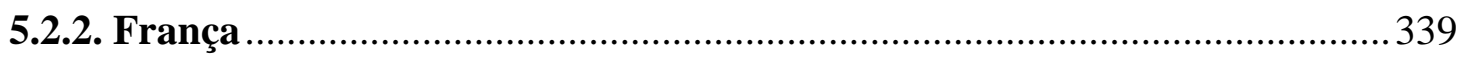

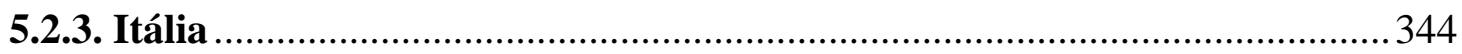

5.3. Erro substancial em alienação de participação societária: o erro próprio.......348 
5.4. Erro substancial em alienação de participação societária: o erro obstativo ... 360 5.5. Erro substancial em alienação de participação societária: o erro nos motivos

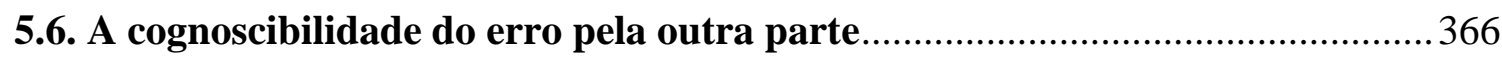

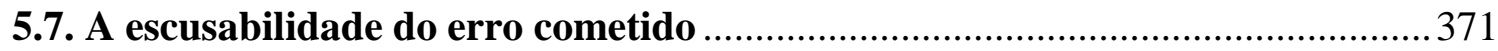

5.8. Restituição das partes ao statu quo ante e indenização do interesse negativo .377

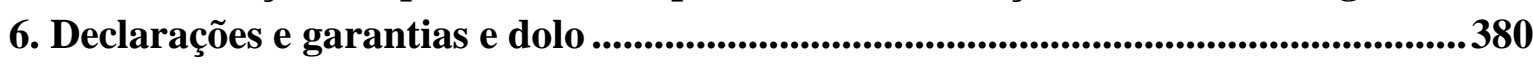

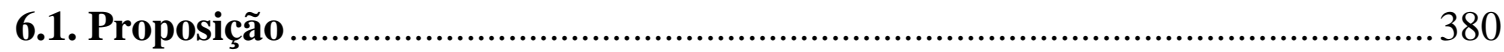

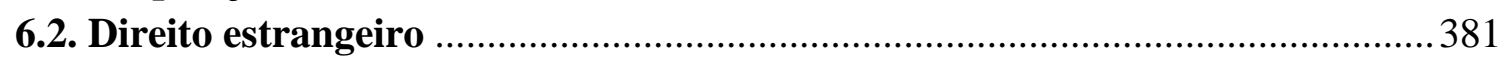

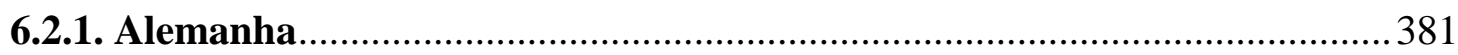

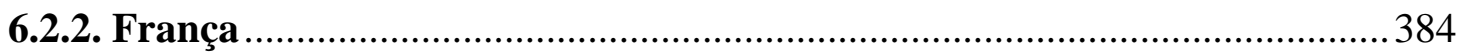

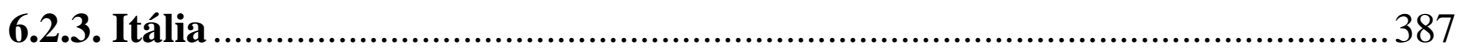

6.3. Aplicabilidade do dolo à alienação de participação societária...........................390

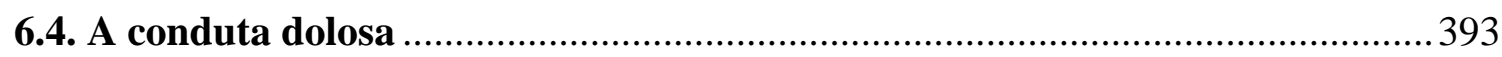

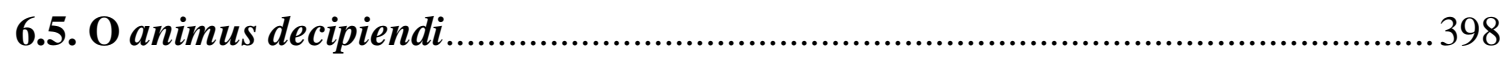

6.6. O dolo essencial na alienação de participação societária .................................403

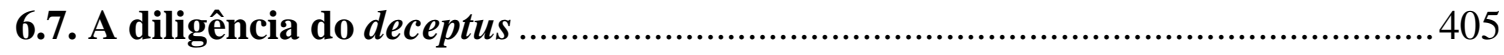

6.8. Dolo de terceiro, dolo do representante e os envolvidos na operação ............... 408

6.9. Reparação de danos e restituição das partes ao statu quo ante ........................412

7. Declarações e garantias e vícios redibitórios e evicção..............................................415

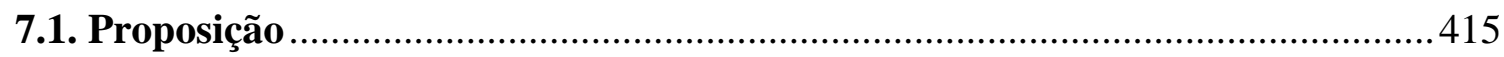

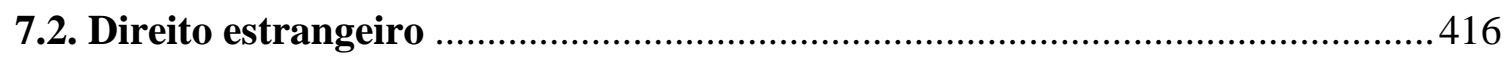

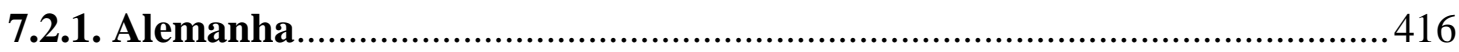

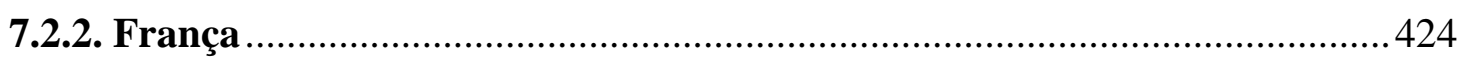

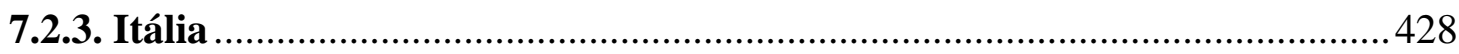

7.3. Remota aplicabilidade do regime de vícios redibitórios e evicção à alienação de participação societária na ausência de declarações e garantias.............................431

7.4. Dificuldades aplicativas do regime de vícios redibitórios à alienação de

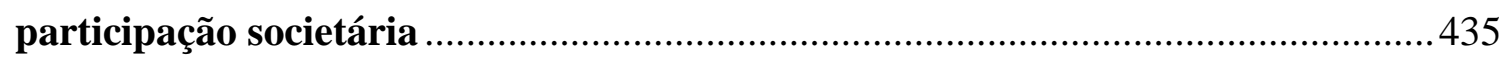

7.4.1. Inadequação ao conceito de vício grave do objeto......................................435

7.4.2. Dificuldade de determinar o caráter oculto do vício ....................................446

7.4.3. Inadequação das consequências do regime de vícios redibitórios............... 451

7.5. Não subsunção das declarações e garantias ao regime de vícios e evicção .......458

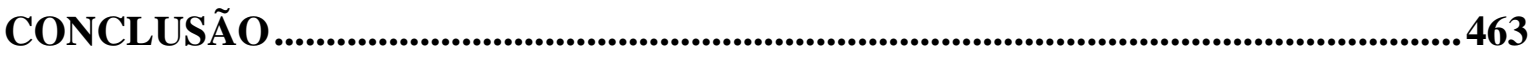

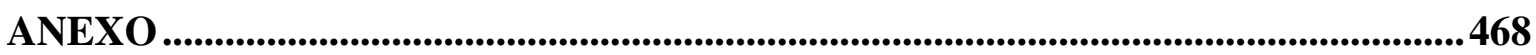

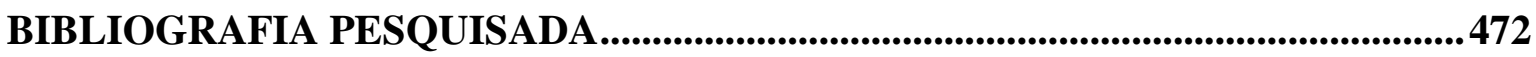

JURISPRUDÊNCIA PESQUISADA .........................................................................503 


\section{INTRODUÇÃO: COLOCAÇÃO DO PROBLEMA}

\section{Preliminares}

O uso das cláusulas de declarações e garantias na prática contratual brasileira talvez seja o melhor exemplo de "transplante acrítico de soluções estrangeiras". ${ }^{1}$ Pegou-se uma cláusula utilizada em contratos oriundos do common law para equacionar interesses dos contratantes que só se põem em vista das peculiaridades daquele sistema jurídico e se a transplantou para os contratos utilizados no Brasil. Criou-se uma cláusula "Frankenstein": destinada a solucionar problemas que não existem no direito nacional, ou que nele existem sob outros formatos, a demandar respostas também sob outros formatos.

A cláusula de declarações e garantias é uma técnica contratual por meio da qual as partes fazem afirmações positivas ou negativas sobre diversos aspectos do bem objeto do negócio, cuja veracidade e exatidão são garantidas pela parte que presta tais afirmações. ${ }^{2}$ Este conceito pode ser aceito de forma preliminar, mas comporta desenvolvimentos que serão feitos ao longo deste trabalho.

A utilização deste mecanismo na prática anglo-saxã tem origem no instituto da misrepresentation, que, de regra, só se preenche quando o vendedor faz afirmações equivocadas sobre o bem objeto do negócio, mas não quando omite informações. Daí a prática de incluir declarações expressas sobre as qualidades do bem no contrato. No direito romano-germânico, porém, não só há tutela pela omissão de informações relevantes do comprador, como a assunção de responsabilidade em contrato pela presença de qualidades do bem independe de afirmações de fato sobre o mesmo, podendo assumir outras formulações. Na fórmula anglo-saxã, o modo encontrado para alocar a responsabilidade foi fazer a parte prestar uma afirmação de fato para incidir o regime da misrepresentation e, adicionalmente, fazê-la prestar uma promessa contratual de que tais afirmações são verdadeiras (warranty) de forma a conjugar ambos os regimes de responsabilidade, contratual e extracontratual. A assunção de responsabilidade acabou adotando o formato de uma declaração de fato, do tipo "o vendedor declara e garante que a sociedade possui tais qualidades...". Uma fórmula genuinamente nacional poderia ser posta como um

\footnotetext{
${ }^{1}$ A expressão é de Judith Martins-Costa (MARTINS-COSTA, Judith. Autoridade e utilidade da doutrina: a construção dos modelos doutrinários. in: MARTINS-COSTA, Judith (org.), Modelos de Direito Privado. São Paulo: Marcial Pons, 2014, p. 22).

${ }^{2}$ MENDES-MEDEIROS, Mariana. Cláusulas de declarações e garantias nos contratos internacionais de aquisição de empresas ou ativos. Dissertação (Mestrado em Direito) - Faculdade de Direito, Universidade de São Paulo, São Paulo, 2006, p. 178.
} 
compromisso do vendedor de provocar determinado resultado, independentemente da apresentação de fatos passados ou presentes, como por exemplo "o vendedor assume responsabilidade caso a sociedade X não tenha tais qualidades...". Na prática negocial, porém, impôs-se o modelo anglo-saxão e cada vez mais têm proliferado cláusulas de declarações e garantias, ou representations and warranties. Cabe ao jurista analisar como tais modelos estrangeiros ${ }^{3}$ acomodam-se aos institutos jurídicos nacionais, quais seus limites e como podem modificar os institutos tradicionais da nossa cultura jurídica.

Não é tarefa deste estudo apontar as causas dessa transposição de institutos. Podese imaginar que a alienação de participação societária seja o principal veículo deste movimento por conta da crescente onda de aquisições internacionais de empresas, na qual o Brasil figura como receptor do investimento e, portanto, em larga dose sujeito aos esquemas contratuais do investidor. Muitas vezes o investidor estrangeiro é uma grande companhia que possui um modelo padrão de contrato para aquisição de empresas, e seus advogados buscam aplicá-lo mundo afora com mínimas modificações.

De um ponto de vista prático, a razão de ser da cláusula de representations and warranties no common law é retirar a responsabilidade das partes em um contrato de alienação de participação societária dos esquemas ordinários de regulação jurídica, de forma a manter o alienante responsável por determinadas vicissitudes da sociedade-alvo mesmo após sua saída, total ou parcial, do quadro societário. ${ }^{4}$ Para compreender a função das declarações e garantias é preciso primeiro entender como é disciplinada a responsabilidade das partes no common law, para a partir daí identificar sua correta adaptação ao direito brasileiro.

Desta forma, o presente trabalho despenderá suas páginas introdutórias analisando os traços principais do direito contratual no common law para compreender a inserção da cláusula de declarações e garantias no contexto de uma alienação de participação societária. Não será feita uma extensa análise do direito contratual no common law, o que fugiria ao escopo deste trabalho, mas apenas as principais razões que levam as partes a

\footnotetext{
${ }^{3}$ Modelos jurídicos, segundo Judith Martins-Costa, são estruturas normativas referidas às fontes de produção jurídica. Os modelos podem ser prescritivos ou hermenêuticos. Os primeiros, que aqui nos interessam, resultam da conjugação de dois ou mais princípios ou regras para formar estruturas normativas que direcionam condutas dentro de um dado segmento da realidade (MARTINS-COSTA, Judith. A boa-fé no direito privado: critérios para a sua aplicação. São Paulo: Marcial Pons, 2015, p. 265-266). Dentre os modelos prescritivos, encontram-se os modelos legais, jurisprudenciais, negociais e costumeiros, as declarações e garantias constituindo exemplo de modelo negocial.

${ }^{4}$ KRAIEM, Ruben. Leaving money on the table: contract practice in a low-trust environment. Columbia Journal of Transnational Law, vol. 42, 2004, p. 726.
} 
estipular declarações e garantias e a técnica contratual empregada para tanto. Ao fim desta introdução, teremos condições de expor o problema que as declarações e garantias visam a resolver no common law e estaremos aptos a enxergar como esse problema pode ser resolvido no direito nacional.

Na Parte I do trabalho, será analisada a fattispecie cláusula de declarações e garantias. Procuraremos delimitar o seu sentido, suas funções e a sua colocação na escala tipológica, afinal, para analisar a natureza jurídica e o regime da cláusula que nos propomos a examinar, sendo preciso primeiro delimitar o objeto de exame.

Para completar a delimitação do objeto de estudo, na Parte II investigaremos em que consiste a alienação de participação societária e seu objeto. Sem tal incursão, o objeto de estudo não estaria bem definido.

Na Parte III analisamos a natureza jurídica da cláusula de declarações e garantias em alienações de participação societária e tentaremos indicar as consequências jurídicas aplicáveis à falsidade das declarações. Faremo-lo testando seis hipóteses que, à primeira vista, parecem aplicáveis: obrigação de garantia, obrigação de dar, responsabilidade précontratual, erro, dolo e vícios redibitórios e evicção. Nossa análise concentra-se na forma de relacionamento das declarações e garantias com cada um destes institutos, e não necessariamente na identificação de um único regime jurídico aplicável. Até porque, como ver-se-á, as declarações e garantias se nos afiguram polimorfas, não apresentando natureza jurídica unívoca, podendo interagir de maneiras diferentes com diversos institutos.

Feitas estas considerações preliminares, podemos passar à exposição do problema a partir do direito contratual do common law.

\section{As condições de entorno do direito contratual no common law}

Para compreender a função exercida pela cláusula de declarações e garantias nos países de common law, é preciso antes entender os incentivos existentes naquele sistema para que as partes desçam ao trabalho de elaborar longas, detalhadas e minuciosas obras contratuais. É na cláusula de declarações e garantias que estes incentivos tomam maior densidade, visto que ali há uma tentativa de cobrir todas as infinitas eventualidades possíveis de ocorrer em uma sociedade, capazes de afetar negativamente o interesse do 
adquirente. Listamos abaixo seis traços principais que incentivam esta abordagem na elaboração de contratos.

\subsection{Análise objetiva dos termos que formam o conteúdo contratual}

Para que uma promessa se torne parte do contrato nos países de common law, é necessária uma certeza muito grande de que as partes quiseram tratar essa disposição como verdadeiro conteúdo do contrato. Neste sentido, coloca-se a questão de saber se as declarações feitas pelas partes antes da celebração do contrato chegam a tornar-se conteúdo contratual (terms of the contract), ou se ficam no campo das simples declarações précontratuais que não entram para o seu conteúdo (mere representations). ${ }^{5}$

O ponto de partida na formação do contrato certamente é o acordo de vontades entre as partes. Mas esse acordo é visto a partir de um ponto de vista absolutamente objetivado no common law. Coloca-se grande ênfase na análise dos atos objetivamente praticados pelas partes para chegar ao acordo e não tanto nas suas circunstâncias subjetivas. ${ }^{6}$ Esse teste costuma desdobrar-se na presença de alguns requisitos objetivos, a saber: quanto maior a distância no tempo entre a declaração e a manifestação final do acordo contratual, menor a chance de tal declaração ter sido incorporada ao conteúdo do contrato $;^{7}$ quanto maior a importância para a contraparte de que a declaração seja verdadeira, maior a chance de ser uma promessa contratual; ${ }^{8}$ se a parte que faz a declaração estiver em melhor posição de confirmar sua veracidade, também será maior a chance de tal declaração ser considerada parte do contrato $;{ }^{9}$ e, por fim, se a declaração feita

${ }^{5}$ CHITTY, Joseph Junior. Chitty on contracts. vol. 1: general principles. 32a ed. Londres: Thomson Reuter, 2015, p. 310 e 1014; FURMSTON, Michael. Cheshire, Fifoot and Furmston's Law of contract. Oxford: Oxford University Press, 2017, p. 177.

${ }^{6}$ CARTWRIGHT, John. Contract Law: an introduction to the English Law of contract for the civil lawyer. $3^{\text {a }}$ ed. Oxford, Portland: Bloomsbury, 2016, p. 68-69; CHITTY, Joseph Junior. Chitty on contracts. vol. 1: general principles. 32a ed. Londres: Thomson Reuter, 2015, p. 306-307; MCKENDRICK, Ewan. Contract: in general. in: BURROWS, Andrew (ed.). Principles of the English Law of obligations. Oxford: Oxford University Press, 2015, p. 28-29.

${ }^{7}$ FURMSTON, Michael. Cheshire, Fifoot and Furmston's Law of contract. Oxford: Oxford University Press, 2017, p. 178-179; CHITTY, Joseph Junior. Chitty on contracts. vol. 1: general principles. 32a ed. Londres: Thomson Reuter, 2015, p. 1014 (citando jurisprudência); VOSS, Stefan Friedrich. Warranties in Unternehmenskaufverträgen - Struktur und Wirkungsweise anglo-amerikanischer Gewährleistungskataloge in Unternehmenskaufverträgen, die deutschem Recht unterliegen. Tübingen: MVK Medien Verlag Köhler, 2002, p. 22.

${ }^{8}$ CHITTY, Joseph Junior. Chitty on contracts. vol. 1: general principles. $32^{\mathrm{a}}$ ed. Londres: Thomson Reuter, 2015, p. 1014 (citando jurisprudência); VOSS, Stefan Friedrich. Warranties in Unternehmenskaufverträgen Struktur und Wirkungsweise anglo-amerikanischer Gewährleistungskataloge in Unternehmenskaufverträgen, die deutschem Recht unterliegen. Tübingen: MVK Medien Verlag Köhler, 2002, p. 22.

${ }^{9}$ FURMSTON, Michael. Cheshire, Fifoot and Furmston's Law of contract. Oxford: Oxford University Press, 2017, p. 179-183; CHITTY, Joseph Junior. Chitty on contracts. vol. 1: general principles. 32a ed. Londres: 
na fase pré-contratual deixa de constar do acordo final cristalizado em contrato escrito, será pequena a chance de ser considerada um term of the contract. ${ }^{10}$ Nesse último caso, entende-se que, se as partes discutiram a questão, mas optaram por não incluí-la no documento final, é porque não pretendiam atribuir-lhe eficácia de contrato. Para evitar incertezas sobre se as declarações feitas entre as partes justificam pretensões contratuais ou se constituem mere misrepresentations, as partes acabam inserindo-as no próprio instrumento contratual.

\subsection{Ausência de regulação dos tipos contratuais na lei}

Contribui para a preparação de longas obras contratuais o fato de o common law não dispor de tipos contratuais fixados em lei, como ocorre nos países de tradição romanogermânica (a exemplo do Título VI do Livro I da Parte Especial do nosso Código Civil). As partes não podem simplesmente escolher a regulação de um tipo e fixar em contrato apenas questões específicas não reguladas no tipo ou questões em que queiram afastar a disciplina dispositiva do tipo. As partes precisam tomar a iniciativa de regular em contrato todos os aspectos relevantes do negócio. ${ }^{11}$

John Cartwright explica que essa característica decorre do fato de o common law não ter construído seu direito contratual a partir da recepção do direito romano, onde o pacto deveria encaixar-se nos modelos de um dos contratos nominados para ser tratado

Thomson Reuter, 2015, p. 1014 (citando longa jurisprudência); VOSS, Stefan Friedrich. Warranties in Unternehmenskaufverträgen - Struktur und Wirkungsweise anglo-amerikanischer Gewährleistungskataloge in Unternehmenskaufverträgen, die deutschem Recht unterliegen. Tübingen: MVK Medien Verlag Köhler, 2002, p. 22. O principal caso neste sentido é Dick Bentley Productions Ltd. v. Harold Smith (Motors) Ltd. [1965] 1 WLR 623, no qual o vendedor de um automóvel usado afirmou que este não tinha rodado mais de 20.000 milhas, quando na verdade, já tinha passado as 100.000, o que levou a Corte a considerar a declaração uma promessa contratual (warranty). Já no caso Oscar Chess Ltd. v. Williams [1957] 1 WLR 370, o vendedor de um automóvel afirmara que o veículo era modelo 1948, baseando-se na alteração do registro do automóvel feita por um terceiro, quando na verdade tratava-se de um modelo 1939. A Court of Appeals considerou tratar-se de uma simples representation.

${ }^{10}$ FURMSTON, Michael. Cheshire, Fifoot and Furmston's Law of contract. Oxford: Oxford University Press, 2017, p. 179; CHITTY, Joseph Junior. Chitty on contracts. vol. 1: general principles. 32a ed. Londres: Thomson Reuter, 2015, p. 1014-1015 (citando jurisprudência); VOSS, Stefan Friedrich. Warranties in Unternehmenskaufverträgen - Struktur und Wirkungsweise anglo-amerikanischer Gewährleistungskataloge in Unternehmenskaufverträgen, die deutschem Recht unterliegen. Tübingen: MVK Medien Verlag Köhler, 2002, p. 22.

${ }^{11}$ CARTWRIGHT, John. Contract Law: an introduction to the English Law of contract for the civil lawyer. $3^{\mathrm{a}}$ ed. Oxford, Portland: Bloomsbury, 2016, p. 62-63; VOSS, Stefan Friedrich. Warranties in Unternehmenskaufverträgen - Struktur und Wirkungsweise anglo-amerikanischer Gewährleistungskataloge in Unternehmenskaufverträgen, die deutschem Recht unterliegen. Tübingen: MVK Medien Verlag Köhler, 2002, p. 22. 
como contrato. ${ }^{12}$ Obviamente o common law reconhece a existência de diferentes tipos contratuais, como a compra e venda, prestação de serviços etc., apenas não desenvolveu corpos de normas para regular a formação, o conteúdo e os efeitos especificamente a nível de cada um dos tipos. Todos os contratos são regulados pelos mesmos princípios e pelas mesmas regras. ${ }^{13}$ Exemplo disso é a ausência de capítulos específicos para tipos contratuais no Restatement (2nd) of Contracts elaborado pelo American Law Institute.

Joseph Chitty ressalta que, apesar da abordagem do direito contratual do common law ser a de não tipificar contratos em lei, ${ }^{14}$ alguns tipos lograram reconhecimento na legislação (como o transporte marítimo de coisas e de seguro marítimo) e, outros, no direito costumeiro, com a principal consequência neste último caso de possibilitar aos tribunais extrair termos implícitos do contrato que derivam não do acordo das partes, mas do tipo contratual em si. $^{15}$

\subsection{Reduzido campo de atuação da boa-fé}

Um terceiro traço característico do common law é a inexistência de um dever genérico de agir segundo a boa-fé seja na fase de tratativas contratuais quanto na fase de execução do contrato. ${ }^{16}$ No reconhecido julgado Walford v. Miles, a House of Lords inglesa chegou mesmo a rejeitar a pactuação de uma obrigação de negociar segundo o princípio da boa-fé, pois isto iria contra a natural contraposição de interesses das partes de um contrato. ${ }^{17}$ Assim, não existem, em regra, deveres de informar, de respeitar os interesses da contraparte ou mesmo de agir com lealdade durante as negociações, podendo a parte até mesmo agir segundo padrões que seriam considerados abusivos num sistema de civil law para atingir seus interesses.

John Cartwright aponta três ordens de razões para inexistência de um dever genérico de agir segundo a boa-fé. Primeiro, há uma certa relutância dos tribunais de países

${ }^{12}$ CARTWRIGHT, John. Contract Law: an introduction to the English Law of contract for the civil lawyer. $3^{\mathrm{a}}$ ed. Oxford, Portland: Bloomsbury, 2016, p. 55-56.

${ }^{13}$ CARTWRIGHT, John. Contract Law: an introduction to the English Law of contract for the civil lawyer. $3^{\mathrm{a}}$ ed. Oxford, Portland: Bloomsbury, 2016, p. 58; FURMSTON, Michael. Cheshire, Fifoot and Furmston's Law of contract. Oxford: Oxford University Press, 2017, p. 31.

${ }^{14}$ CHITTY, Joseph Junior. Chitty on contracts. vol. 1: general principles. $32^{\mathrm{a}}$ ed. Londres: Thomson Reuter, 2015, p. 90, nota de rodapé n. 688.

${ }^{15}$ CHITTY, Joseph Junior. Chitty on contracts. vol. 1: general principles. $32^{\mathrm{a}}$ ed. Londres: Thomson Reuter, 2015, p. 91-92.

${ }^{16}$ CHITTY, Joseph Junior. Chitty on contracts. vol. 1: general principles. $32^{\mathrm{a}}$ ed. Londres: Thomson Reuter, 2015, p. 35-38.

${ }^{17}$ Walford v. Miles [1992] 2 A.C. 128 [1992] 1 All E.R. 453 (HL). 
de common law em generalizar princípios abstratos, preferindo, em vez, particularizar suas razões no caso concreto. Daí a dificuldade para impor um dever geral de agir conforme a boa-fé. ${ }^{18}$ Segundo, a ideia de certeza do direito, tão cara aos tribunais de common law, ficaria comprometida com a inserção de um princípio como a boa-fé, marcado pelo seu caráter vago. ${ }^{19-20}$ Terceiro, em contratos bilaterais, onde a contraposição de interesses entre as partes é natural, a posição dos tribunais é que seria inconsistente impor um dever de negociar em boa-fé, ${ }^{21}$ muito embora se admita um tal dever em contratos de cooperação, como os de parceria. ${ }^{22}$ Como corolário, rejeita-se normalmente nos países de common law uma obrigação de informar a outra parte, assim como também se rejeita a obrigação de indenizar por ruptura de negociações. ${ }^{23}$

A jurisprudência nos países do common law desenvolveu a figura do promissory estoppel, que cumpre de certa forma o papel do princípio da boa-fé no sistema romanogermânico. Pela doutrina do estoppel, a pessoa que faz uma declaração fica impedida de voltar atrás em tal declaração, se a contraparte nela tiver confiado. Mas o estoppel não cria um novo direito para a outra parte, ou uma nova causa de ação (cause of action), daí a corriqueira locução "estoppel is a shield not a sword". A parte atingida pelo estoppel apenas fica impedida de voltar atrás em sua declaração e, eventualmente, tem de arcar com os prejuízos causados. ${ }^{24} \mathrm{O}$ promissory estoppel está muito mais relacionado, assim, à

${ }^{18}$ CARTWRIGHT, John. Contract Law: an introduction to the English Law of contract for the civil lawyer. $3^{\mathrm{a}}$ ed. Oxford, Portland: Bloomsbury, 2016, p. 64-65 e 75-76.

${ }^{19}$ CARTWRIGHT, John. Contract Law: an introduction to the English Law of contract for the civil lawyer. $3^{\text {a }}$ ed. Oxford, Portland: Bloomsbury, 2016, p. 65-66 e 76-78.

${ }^{20}$ Sobre a vagueza semântica inerente às cláusulas gerais, veja-se MARTINS-COSTA, Judith. A boa-fé no direito privado: critérios para a sua aplicação. São Paulo: Marcial Pons, 2015, p. 131-141.

${ }^{21}$ CARTWRIGHT, John. Contract Law: an introduction to the English Law of contract for the civil lawyer. $3^{\mathrm{a}}$ ed. Oxford, Portland: Bloomsbury, 2016, p. 66 e 78-79.

${ }^{22}$ CARTWRIGHT, John. Contract Law: an introduction to the English Law of contract for the civil lawyer. $3^{\text {a }}$ ed. Oxford, Portland: Bloomsbury, 2016, p. 66. Chitty adiciona ao rol dos contratos em que se admite um dever de agir segundo a boa-fé aqueles em que uma parte tem de considerar os interesses da outra, como no contrato de mandato (agency), e aqueles em que existe obrigação especificamente estipulada de agir segundo boa-fé (CHITTY, Joseph Junior. Chitty on contracts. vol. 1: general principles. $32^{\mathrm{a}}$ ed. Londres: Thomson Reuter, 2015, p. 43-50). O autor ainda reconduz as ideias de razoabilidade e justiça contratual à boa-fé, seja na interpretação contratual, na definição de termos contratuais implícitos e na adequação dos remédios jurídicos cabíveis em caso de violação contratual (p. 50-59).

${ }^{23}$ CARTWRIGHT, John. Contract Law: an introduction to the English Law of contract for the civil lawyer. $3^{\mathrm{a}}$ ed. Oxford, Portland: Bloomsbury, 2016, p. 80-82.

${ }^{24}$ MCKENDRICK, Ewan. Contract: in general. in: BURROWS, Andrew (ed.). Principles of the English Law of obligations. Oxford: Oxford University Press, 2015, p. 18-20; FURMSTON, Michael. Cheshire, Fifoot and Furmston's Law of contract. Oxford: Oxford University Press, 2017, p. 132-136; CHITTY, Joseph Junior. Chitty on contracts. vol. 1: general principles. $32^{\mathrm{a}}$ ed. Londres: Thomson Reuter, 2015, p. 459 e 469-470; CARTWRIGHT, John. Contract Law: an introduction to the English Law of contract for the civil lawyer. $3^{\mathrm{a}}$ ed. Oxford, Portland: Bloomsbury, 2016, p. 82-83 e 143-153. Veja-se também os casos paradigmáticos julgados pelas cortes inglesas em Central London Property Trust Ltd. v. High Trees House Ltd. [1947] KB 130 e Jorden v. Money [1854] 5 HL Cas 185. 
proibição de comportamento contraditório, o que ao menos no direito brasileiro corresponderia à função da boa-fé como limite ao exercício disfuncional de posições jurídicas, deixando a descoberto a função hermenêutica e a de criação de deveres. ${ }^{25}$

Neste ponto, o direito norte-americano difere sensivelmente do direito inglês, pois a obrigação de negociar segundo boa-fé está não só no §1-304 do Uniform Commercial Code ${ }^{26}$ mas também no $\$ 205$ do Restatement (2nd) of Contracts. ${ }^{27}$ Allan Farnsworth aponta que a visão tradicional é de ampla liberdade para negociar (freedom of negotiation), tendo ambas as partes possibilidade de, a qualquer momento, desistir das tratativas. A parte que entra em negociações com a expectativa de auferir ganhos com o contrato assume o risco de eventuais perdas, caso o contrato não se concretize. Segundo Farnsworth, esta abordagem está amparada na visão tradicional do contrato dentro do esquema de oferta e aceitação: a parte ofertada está protegida pela possibilidade de aceitar a oferta antes da sua revogação. Por isso não há simpatia pelo ofertado que vê a celebração do contrato frustrada pela revogação abrupta da oferta. O autor, porém, aponta que os fundamentos de tal doutrina vão cada vez mais se erodindo, pois as complexas negociações atuais de contratos dificilmente se deixam apreender no esquema tradicional de oferta e aceitação. ${ }^{28}$

A principal razão para não se impor, no common law, uma obrigação de fair dealing na etapa pré-contratual, é que isso criaria um desincentivo para as partes entrarem em negociações, sabendo que podem estar assumindo um risco de responsabilização pela não conclusão do contrato. Farnsworth conclui, assim, que não há razões para abandonar a visão tradicional do common law, que atribui diminuta relevância ao princípio da boa-fé (fair dealing) na fase pré-contratual. ${ }^{29}$

\subsection{Princípio caveat emptor}

Pela doutrina do caveat emptor, é responsabilidade do adquirente examinar o bem objeto do negócio para identificar possíveis vícios e, eventualmente, garantir-se contra eles

\footnotetext{
${ }^{25}$ Sobre as três funções do princípio da boa-fé no direito brasileiro, veja-se MARTINS-COSTA, Judith. A boa-fé no direito privado: critérios para a sua aplicação. São Paulo: Marcial Pons, 2015, capítulos 6, 7 e 8.

${ }^{26}$ Uniform Commercial Code, §1-304: "Every contract or duty within the Uniform Commercial Code imposes an obligation of good faith in its performance and enforcement".

${ }^{27}$ Restatement (2nd) of Contracts, §205: "Every contract imposes upon each party a duty of good faith and fair dealing in its performance and its enforcement".

${ }^{28}$ FARNSWORTH, E. Allan. Precontractual liability and preliminary agreements: fair dealing and failed negotiations. Columbia Law Review, vol. 87, n. 2, mar./1987, p. 221-223.

29 FARNSWORTH, E. Allan. Precontractual liability and preliminary agreements: fair dealing and failed negotiations. Columbia Law Review, vol. 87, n. 2, mar./1987, p. 242-243.
} 
por meio de garantias contratuais específicas. O risco quanto a vícios da coisa fica a cargo do adquirente, pois o alienante só responde pelos vícios se tiver agido de má-fé. ${ }^{30}$

O princípio caveat emptor também encontra aplicação nos países de civil law. Porém, sua amplitude é mais limitada, pois se reconhece à boa-fé o papel de criação de deveres informativos na fase contratual, ${ }^{31}$ ao passo que, no common law, o dever de informar é admitido apenas em situações bem mais restritas. Na Inglaterra, a menos que a falta de informação configure misrepresentation, reconhece-se um dever de informar em situações bastante específicas, como relações consumeristas, contratos de seguro, relações marcadas por acentuada confiança, em negociações de contratos de parceria e transações entre membros da mesma família. ${ }^{32}$ Nos Estados Unidos, embora o §1-304 do Uniform Commercial Code imponha uma obrigação de agir segundo a boa-fé, não se considera a mesma uma fonte criadora de novos deveres, mas apenas um mandamento para que os contratos sejam interpretados e executados segundo os padrões comerciais. Ou seja, a boafé age de forma acoplada ao contrato. ${ }^{33} \mathrm{Em}$ ambos os países, portanto, o adquirente não é tutelado senão de forma casuística por um dever de informar, restando-lhe como princípio geral a inteira responsabilidade por procurar sua própria informação.

O principio caveat emptor, porém, vem sendo sistematicamente mitigado, sobretudo em operações imobiliáras. Alex Johnson justifica tal mitigação com base no fato de que o princípio caveat emptor surge historicamente em um momento em que a sociedade era essencialmente agrária, e as transações imobiliárias envolviam substancialmente transferência de propriedade rural. Qualquer informação relevante para o negócio poderia ser facilmente obtida pelo adquirente através de uma simples inspeção visual do imóvel. Por isso não se exigia a divulgação de informações pelo alienante. Com a evolução da sociedade e o incremento na complexidade das transações, a premissa que

\footnotetext{
${ }^{30}$ BRIDGE, Michael J. The sale of goods. $3^{\text {a }}$ ed. Oxford: Oxford University Press, 2014, p. 341; VOSS, Stefan Friedrich. Warranties in Unternehmenskaufverträgen - Struktur und Wirkungsweise angloamerikanischer Gewährleistungskataloge in Unternehmenskaufverträgen, die deutschem Recht unterliegen. Tübingen: MVK Medien Verlag Köhler, 2002, p. 32-33. Gerard McMeel inclusive relaciona a doutrina do caveat emptor à regra tradicional de irrelevância do erro unilateral no common law, já que o risco de vícios da coisa fica a cargo do aquirente (MCMEEL, Gerard. The construction of contracts: interpretation, implication and rectification. $2^{\mathrm{a}}$ ed. Oxford: Oxford University Press, 2011, p. 537).

${ }^{31}$ No Brasil, veja-se MARTINS-COSTA, Judith. A boa-fé no direito privado: critérios para a sua aplicação. São Paulo: Marcial Pons, 2015, capítulo 7.

${ }_{32}$ CARTWRIGHT, John. Contract Law: an introduction to the English Law of contract for the civil lawyer. $3^{\mathrm{a}}$ ed. Oxford, Portland: Bloomsbury, 2016, p. 80-81; ANDREWS, Neil. Contract rules: decoding English Law. Plymouth: Intersentia, 2016, p. 119-121.

${ }^{33}$ SCOTT, Robert E.; KRAUS, Jody S. Contract law and theory. $5^{\mathrm{a}}$ ed. Durham: Carolina Academic Press, 2013, p. 89-90.
} 
justifica o caveat emptor já não é mais verdadeira. Por isso, aceita-se um ônus maior do alienante de fornecer informações, já não acessíveis a um simples exame do adquirente. ${ }^{34}$

Atualmente, o significado da doutrina caveat emptor reside principalmente em impor ao adquirente um ônus de tomar todas as medidas preventivas necessárias para proteção de seus interesses, sob pena de, não o fazendo, arcar com um negócio desvantajoso..$^{35}$

\subsection{Parol evidence rule}

Por meio da parol evidence rule (também conhecida como four corners of the contract rule) afirma-se que um contrato escrito é completo em si mesmo, suas disposições devendo ser interpretadas exclusivamente de acordo com o que está contido no documento contratual. O texto do contrato não pode ser afetado por outras coisas que as partes fizeram ou disseram até chegar no documento escrito. Daí a ideia de "four corners": o contrato se lê apenas pelo que está escrito nos quatro cantos da página do documento que o contém. ${ }^{36} \mathrm{Em}$ curtas palavras, a parol evidence rule veda a interpretação do escrito pelo não-escrito.

A descrição mais comum da parol evidence rule é a de que evidências verbais não devem ser admitidas para adicionar, modificar ou contradizer o instrumento escrito. ${ }^{37}$ Chitty descreve-a da seguinte maneira: "[i]f there is a contract which has been reduced to writing, verbal evidence is not allowed to be given (...) so as to add or substract from, or in any manner to vary or qualify the contract". 38

$\mathrm{Na}$ interpretação do conteúdo do contrato não são consideradas, portanto, comunicações nem as negociações entre as partes antes da celebração do contrato escrito. Não só a utilização de elementos verbais é vedada na tarefa de interpretação, mas igualmente acertos escritos, minutas contratuais e protocolos de intenções trocados entre as partes são irrelevantes para investigar o conteúdo do contrato escrito. ${ }^{39}$ De certa forma, a

${ }^{34}$ JOHNSON JR., Alex M. An economic analysis of the duty to disclose information: lessons learned from the caveat emptor doctrine. San Diego Law Review, vol. 45, 2008, p. 97-99 e 118.

35 VOSS, Stefan Friedrich. Warranties in Unternehmenskaufverträgen - Struktur und Wirkungsweise angloamerikanischer Gewährleistungskataloge in Unternehmenskaufverträgen, die deutschem Recht unterliegen. Tübingen: MVK Medien Verlag Köhler, 2002, p. 33.

${ }^{36}$ CALNAN, Richard. Principles of contractual interpretation. Oxford: Oxford University Press, 2013, p. 24.

37 Jacobs v. Batavia [1924] 1 Ch 287 at 296. Veja-se também ANDREWS, Neil. Contract rules: decoding English Law. Plymouth: Intersentia, 2016, p. 169.

${ }^{38}$ CHITTY, Joseph Junior. Chitty on contracts. vol. 1: general principles. $32^{\mathrm{a}}$ ed. Londres: Thomson Reuter, 2015, p. 1070.

${ }^{39}$ VOSS, Stefan Friedrich. Warranties in Unternehmenskaufverträgen - Struktur und Wirkungsweise anglo- 
parol evidence rule torna o contrato escrito um sistema hermeticamente fechado em si mesmo para evitar incertezas quanto a sua interpretação.

Richard Calnan adverte, porém, que a regra não deve ser levada tão longe. Se as partes quiseram que o seu contrato fosse mais do que um simples documento escrito, seria inapropriado tratar o documento escrito como se fosse a única fonte do acordo entre as partes. ${ }^{40}$ Como exceções à regra, as partes podem celebrar acordos colaterais ao contrato verbalmente ou por escrito, além de poderem trazer elementos extracontratuais para provar questões relativas à invalidade do negócio. ${ }^{41}$

Gerard McMeel relata, no entanto, que a regra vem sofrendo amenizações a partir do século XX, de forma a dar valor para o cenário mais amplo em que as partes celebraram o contrato, e não apenas à letra do contrato. Aceita-se, por exemplo, evidências extrínsecas quanto às circunstâncias de fato conhecidas de ambas as partes, ao objeto do contrato ou ao pano de fundo jurídico e regulatório das partes. Mas mesmo nessa versão moderna da parol evidence rule, excluem-se as intenções subjetivas e negociações prévias entre as partes (como minutas contratuais, por exemplo). ${ }^{42}$ Em sua versão mais amenizada, pode-se dizer que a parol evidence rule não nega a possibilidade de evidências extrínsecas serem utilizadas para interpretar o contrato, mas apenas que o instrumento contratual deve ter primazia sobre quaisquer outros materiais interpretativos. ${ }^{43}$

No Uniform Commercial Code, § 2-202, está corporificada uma versão desta regra que apenas impede os termos escritos de serem contrariados por elementos não-escritos, mas permite que o documento escrito seja explicado ou complementado por outros acordos ou pelas negociações entre as partes. ${ }^{44}$

amerikanischer Gewährleistungskataloge in Unternehmenskaufverträgen, die deutschem Recht unterliegen. Tübingen: MVK Medien Verlag Köhler, 2002, p. 33-34.

${ }^{40}$ CALNAN, Richard. Principles of contractual interpretation. Oxford: Oxford University Press, 2013, p. 24.

${ }^{41}$ ANDREWS, Neil. Contract rules: decoding English Law. Plymouth: Intersentia, 2016, p. 169-170. No mesmo sentido, citando ainda outros casos em que se admite prova por meio de elementos externos ao contrato, TREITEL, Günter. The law of contract. 11 a ed. Londres: Sweet \& Maxwell, 2003, p. 193-201.

${ }^{42}$ MCMEEL, Gerard. The construction of contracts: interpretation, implication and rectification. Oxford: Oxford University Press, 2011, p. 165-166. O autor dedica longas páginas à matéria, cuja leitura se recomenda fortemente (p. 167-250).

${ }^{43}$ MCMEEL, Gerard. The construction of contracts: interpretation, implication and rectification. Oxford: Oxford University Press, 2011, p. 41.

${ }^{44}$ WHITE, James; SUMMERS, Robert. Uniform commercial code. $6^{a}$ ed. Saint Paul: West Publishing, 2010, p. 116. 
Por outro lado, a parol evidence rule tem o mérito de ressaltar a função precípua do instrumento escrito de conferir certeza jurídica às partes, ${ }^{45}$ mas nada obsta a parte de trazer à apreciação do tribunal elementos de fora do contrato escrito, caso em que o julgador terá de decidir se aceita-o ou não. Para evitar tais incertezas formou-se a praxe de incluir as chamadas entire agreement clauses, ou seja, cláusulas pelas quais as próprias partes limitam o acervo interpretativo ao documento escrito do contrato. No fim das contas, as cláusulas de entire agreement acabaram substituindo a parol evidence rule como mecanismo de identificação do conteúdo contratual. ${ }^{46}$

Em suma, pode-se dizer com John Cartwright que o sentido da parol evidence rule está em criar "uma inferência quanto a quaisquer declarações ou promessas feitas por uma das partes à outra durante as negociações, que não venham a ser repetidas no documento escrito, de que estas não deveriam ser contratualmente vinculativas" (tradução livre). ${ }^{47}$

\subsection{Regra ejusdem generis}

Um último traço característico do common law que vale ser mencionado neste capítulo introdutório é o apego à regra ejusdem generis, segundo a qual quando uma cláusula contratual enumera várias termos específicos seguidos de um termo geral, deve-se interpretar tal termo geral como sendo restrito às coisas do mesmo gênero daquelas que foram listadas de forma específica. ${ }^{48} \mathrm{Ou}$ seja, o termo geral não é interpretado no seu sentido mais amplo, mas sim no sentido compatível com a classe dos termos específicos que o precedem. ${ }^{49}$

\footnotetext{
${ }^{45}$ CALNAN, Richard. Principles of contractual interpretation. Oxford: Oxford University Press, 2013, p. 25;

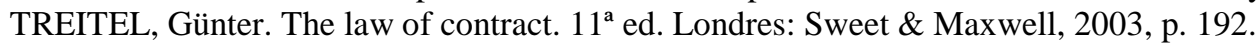

${ }^{46}$ CALNAN, Richard. Principles of contractual interpretation. Oxford: Oxford University Press, 2013, p. 2526.

${ }^{47}$ CARTWRIGHT, John. Contract Law: an introduction to the English Law of contract for the civil lawyer. $3^{\mathrm{a}}$ ed. Oxford, Portland: Bloomsbury, 2016, p. 206 ("But there will be an inference that any statements or promises made by either party to the other during negotiations, which are not repeated in the written document, were not intended to be contractually binding").

${ }^{48}$ PERILLO, Joseph. M. Calamari and Perillo on contracts. $5^{\text {a }}$ ed. Saint Paul: West Publishing, 2003, p. 159.

${ }^{49}$ Essa é a definição da regra dada pelo Black's Law Dictionary: "the ejusdem generis rule is, that where general words follow an enumeration of persons or things, by words of a particular and specific meaning, such general words are not to be construed in their widest extent, but are to be held as applying only to persons or things of the same general kind or class as those specifically mentioned" (BLACK, Henry Campbell. Black's Law dictionary. $5^{\text {a }}$ ed. Saint Paul: West Publishing, 1979, p. 464, verbete "ejusdem generis"). No mesmo sentido, CHITTY, Joseph Junior. Chitty on contracts. vol. 1: general principles. $32^{\mathrm{a}}$ ed. Londres: Thomson Reuter, 2015, p. 1065-1066.
} 
Uma aplicação da regra poderia ser dada no seguinte exemplo, envolvendo cláusula de não-concorrência, tão comum em alienações de participação societária: “o alienante das ações não poderá investir como sócio, gerir, exercer atividade remunerada ou por qualquer outra forma participar de atividade concorrente". Os sintagmas "investir como sócio", "gerir" e "exercer atividade remunerada" estão aí como termos específicos, enquanto que "participar de atividade concorrente" está como termo geral. Como os três termos específicos anteriores referem-se a atividades positivas do alienante das ações, o sintagma "participar de atividade concorrente" deve ser entendido como vedação à prática de atos positivos que contribuam para atividades concorrentes, mas não assim para um não-fazer.

Dada a tendência do common law para colocar toda a regulação do contrato por escrito, a regra ejusdem generis é utilizada por juízes para interpretar as disposições contratuais de forma restritiva. Porém, como observa Richard Calnan, as partes muitas vezes valem-se do termo geral ao fim da enumeração para ampliar o escopo da cláusula, o que pelo menos mitiga a funcionalidade da regra ejusdem generis. ${ }^{50}$ Já Gerard McMeel entende que, embora a máxima latina tenha campo de aplicação, ela não pode ser tomada como mais do que uma presunção de linguagem. ${ }^{51}$

Delineadas estas seis principais características estruturais do direito contratual no common law, compreende-se porque os contratos são tão extensos e detalhistas nos sistemas jurídicos que seguem essa tradição. As partes precisam esforçar-se para criar uma regulação contratual clara, completa e detalhada para conferir segurança a suas relações.

A inserção das cláusulas contratuais por escrito, de fato, evita questionamentos quanto a se o acordo no tocante a um ponto específico da avença chegou a tornar-se term of the contract, passando no teste objetivo aplicado pelos tribunais do common law. Além disso, a inserção do acordo das partes em longas cláusulas contratuais também visa contornar o risco de que parcela relevante do acordo fique de fora do conteúdo do contrato por conta da parol evidence rule, auxiliando também a suprir a falta de regulação legal dos tipos contratuais. Por fim, ausente um dever de negociar segundo boa-fé ou de informar defeitos da coisa (caveat emptor), a melhor proteção para o adquirente será empreender

${ }^{50}$ CALNAN, Richard. Principles of contractual interpretation. Oxford: Oxford University Press, 2013, p. 8283.

${ }^{51}$ MCMEEL, Gerard. The construction of contracts: interpretation, implication and rectification. Oxford: Oxford University Press, 2011, p. 293-295 (citando a evolução da jurisprudência inglesa neste aspecto). 
investigações as mais completas possíveis antes da celebração do negócio, o que em alienações de participação societária é conhecido como due diligence, para descobrir eventuais vícios, resguardando-se o adquirente por meio de garantias contratuais contra eventuais vícios não identificados. Tudo isso por meio de longas enumerações de hipóteses de garantia, de obrigações do alienante e do adquirente para precaver-se contra o risco de interpretações restritivas do contrato.

Tudo isto deixa-nos mais próximos de compreender a razão de ser e da função da cláusula de declarações e garantias nos contratos dos países de common law, mas não exaure a questão. Os seis traços analisados supra constituem incentivos para que as partes se lancem à redação de longas obras contratuais, especialmente extensas e minuciosas cláusulas de declarações e garantias, mas resta ainda analisar a técnica contratual do common law.

\section{A misrepresentation}

Representations são afirmações de fato feitas por uma parte com a intenção de induzir a outra a celebrar o contrato. ${ }^{52}$ Podem consistir em afirmações sobre a qualidade do bem que é objeto do negócio, sobre a capacidade da pessoa de executar o contrato ou ainda sobre uma determinada situação. Neste sentido, as representations distinguem-se dos terms of the contract, porque não chegam a integrar o conteúdo do contrato, ao passo que estes últimos são o próprio conteúdo. As representations apenas induzem a parte a contratar sem constituírem elas próprias parte da regulação objetiva de interesses das partes. ${ }^{53}$

No direito inglês, não são representations aquelas afirmações tão vagas a ponto de não terem efeito algum sobre a decisão de contratar (mere puffs), nem as meras opiniões ou simples crenças de quem faz a declaração. ${ }^{54}$ Característica relevante de uma representation é que esta só pode referir-se a fatos existentes, seja no presente ou no passado. Jamais

${ }^{52}$ ANDREWS, Neil. Contract rules: decoding English Law. Plymouth: Intersentia, 2016, p. 97; STONE, Richard; DEVENNEY, James. The modern law of contract. $12^{\mathrm{a}}$ ed. Abingdon: Routledge, 2017, p. 281; FARNSWORTH, E. Allan. Contracts. $4^{a}$ ed. Nova Iorque: Aspen, 2004, p. 237.

${ }^{53}$ CHITTY, Joseph Junior. Chitty on contracts. vol. 1: general principles. $32^{\mathrm{a}}$ ed. Londres: Thomson Reuter, 2015, p. 645; FURMSTON, Michael. Cheshire, Fifoot and Furmston's Law of contract. Oxford: Oxford University Press, 2017, p. 345.

54 TREITEL, Günter. The law of contract. $11^{\text {a }}$ ed. Londres: Sweet \& Maxwell, 2003, p. 330-331; ANDREWS, Neil. Contract rules: decoding English Law. Plymouth: Intersentia, 2016, p. 103; STONE, Richard; DEVENNEY, James. The modern law of contract. $12^{\mathrm{a}}$ ed. Abingdon: Routledge, 2017, p. 282-283; CHITTY, Joseph Junior. Chitty on contracts. vol. 1: general principles. $32^{\mathrm{a}}$ ed. Londres: Thomson Reuter, 2015, p. 647-648. 
comporta declarações sobre fatos futuros. Quando a parte promete praticar determinado ato no futuro, poderá descumprir o contrato se tal promessa for parte do contrato, mas certamente não estará dando uma falsa representation (misrepresentation)..$^{55}$

Para que a parte possa valer-se dos remédios aplicáveis à misrepresentation no direito inglês, a declaração deve ser unívoca (unambiguous), relevante (material) e o declaratário deve ter nela depositado confiança (reliance). Se a declaração for ambígua, comportando mais de uma interpretação possível, sendo verdadeira em um sentido e falsa em outro, o declarante não será responsável por misrepresentation se a sua interpretação da própria declaração for a verdadeira ou se, apesar de tê-la interpretado no sentido falso, tiver nele acreditado honestamente. ${ }^{56}$ Quanto à relevância, a declaração que se descobre falsa deve ser tal que uma pessoa razoável não teria celebrado o contrato ou não o teria celebrado nos mesmos termos em que o celebrou se soubesse da falsidade da declaração. ${ }^{57}$ Não se considera relevante a misrepresentation se a declaração é correta em sua maior parte e falsa apenas quanto a questões menores que não influenciariam a decisão de uma pessoa razoável. ${ }^{58}$ Mas há duas exceções ao requisito de relevância. A primeira exceção é que a declaração falsa feita de forma intencional sempre sujeita o declarante à responsabilidade por misrepresentation independentemente de sua relevância. A segunda é que qualquer declaração torna-se relevante se o contrato assim dispuser, mesmo que, considerada em si mesma, a representation não tenha tanta relevância. ${ }^{59}$

Mais complexo é o preenchimento do requisito de confiança da parte enganada na declaração. Se a parte não confiou na declaração, então não se pode dizer que foi induzida a contratar por causa da declaração. O declaratário precisa ter recebido a declaração e ter sido decisivamente influenciado por ela. ${ }^{60}$ Assim, se o declaratário conhecia a verdade, não

\footnotetext{
55 TREITEL, Günter. The law of contract. $11^{\mathrm{a}}$ ed. Londres: Sweet \& Maxwell, 2003, p. 331; CHITTY, Joseph Junior. Chitty on contracts. vol. 1: general principles. $32^{\mathrm{a}}$ ed. Londres: Thomson Reuter, 2015, p. 645; FURMSTON, Michael. Cheshire, Fifoot and Furmston's Law of contract. Oxford: Oxford University Press, 2017 , p. 346.

56 TREITEL, Günter. The law of contract. $11^{\mathrm{a}}$ ed. Londres: Sweet \& Maxwell, 2003, p. 335-336.

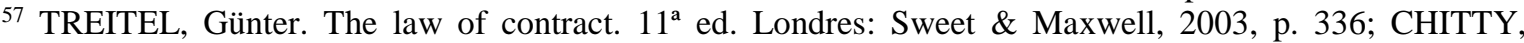
Joseph Junior. Chitty on contracts. vol. 1: general principles. 32a ed. Londres: Thomson Reuter, 2015, p. 670671; FURMSTON, Michael. Cheshire, Fifoot and Furmston's Law of contract. Oxford: Oxford University Press, 2017, p. 353.

${ }^{58}$ ANDREWS, Neil. Contract rules: decoding English Law. Plymouth: Intersentia, 2016, p. 105.

${ }^{59}$ TREITEL, Günter. The law of contract. $11^{\text {a }}$ ed. Londres: Sweet \& Maxwell, 2003, p. 336-337.

${ }^{60}$ ANDREWS, Neil. Contract rules: decoding English Law. Plymouth: Intersentia, 2016, p. 107; CHITTY, Joseph Junior. Chitty on contracts. vol. 1: general principles. $32^{\mathrm{a}}$ ed. Londres: Thomson Reuter, 2015, p. 667; STONE, Richard; DEVENNEY, James. The modern law of contract. 12a ed. Abingdon: Routledge, 2017, p. 287 (ressaltando que a misrepresentation não precisa ser a única razão para celebração do contrato, embora precise ser decisiva).
} 
poderá reclamar da falsidade de uma declaração cuja falsidade era sabida. Do mesmo modo, se o declaratário investiga por si próprio a veracidade da declaração, não será a declaração que o terá induzido a firmar o negócio, mas sim a confiança no seu próprio julgamento. A responsabilidade por misrepresentation persiste ainda que o declaratário tenha tido oportunidade de testar a veracidade da declaração por si próprio, mas não seria razoável exigir-se dele que o fizesse. ${ }^{61}$ Por fim, o requisito de confiança na misrepresentation considera-se preenchido quando a declaração falsa é transmitida ao contratante por meio de terceiros, e não diretamente ao declaratário, bastando que o autor da declaração falsa tenha a intenção de que a declaração seja transmitida ao declaratário ou quando puder contar que a declaração será transmitida ao declaratário (por exemplo, quando um relatório produzido pelo declarante seja transmitido ao banco intermediário da operação contendo informação falsa e este o repasse à contraparte do contrato). ${ }^{62}$

É importante notar ainda que, como regra, a misrepresentation só se concretiza quando efetivamente exista uma declaração falsa. Não configura misrepresentation o mero silêncio quanto a um fato que a contraparte teria interesse em saber. No direito inglês, mesmo se a contraparte está celebrando o negócio com base em uma falsa representação da realidade, não há dever de entregar a informação verdadeira à outra parte, pois se sanciona apenas a parte que fala inverdades, mas não há imposição de obrigações positivas de informar fatos verídicos. Mas há algumas exceções na Inglaterra. Contar uma meiaverdade pode configurar misrepresentation quanto à parte do fato que foi omitida. Também configura misrepresentation deixar de comunicar uma mudança de fatos que torna falsa uma declaração anteriormente prestada que era verdadeira. Em contratos uberrimae fidei, como o seguro, também se aceita que o silêncio configure misrepresentation. ${ }^{63}$

No common law inglês, existem três tipos de misrepresentation: fraudulenta (fraudulent misrepresentation), negligente (negligent misrepresentation) ou inocente (innocent misrepresentation). A fraudulent misrepresentation configura-se quando a declaração é feita com conhecimento de sua falsidade, sem crença na sua veracidade ou

${ }^{61}$ TREITEL, Günter. The law of contract. 11 a ed. Londres: Sweet \& Maxwell, 2003, p. 338-340; ANDREWS, Neil. Contract rules: decoding English Law. Plymouth: Intersentia, 2016, p. 108-109. De forma similar, FURMSTON, Michael. Cheshire, Fifoot and Furmston's Law of contract. Oxford: Oxford University Press, 2017, p. 351-354.

62 TREITEL, Günter. The law of contract. 11 $1^{\mathrm{a}}$ ed. Londres: Sweet \& Maxwell, 2003, p. 340-341.

${ }^{63}$ STONE, Richard; DEVENNEY, James. The modern law of contract. 12 $2^{\mathrm{a}}$ ed. Abingdon: Routledge, 2017, p. 285-287; FURMSTON, Michael. Cheshire, Fifoot and Furmston's Law of contract. Oxford: Oxford University Press, 2017, p. 349-350. 
ainda de forma descuidada, sem importar-se com a veracidade ou falsidade do seu conteúdo. ${ }^{64}$

Já a negligent misrepresentation consiste na prestação de declaração falsa em violação a um dever de cuidado devido pelo declarante frente ao declaratário. A questão então passa a ser a de definir quando está presente um tal dever de cuidado. Günter Treitel classifica em três grupos os casos em que pode-se afirmar a presença de um tal dever. $\mathrm{O}$ primeiro grupo de casos caracteriza-se quando a parte presta a declaração falsa no exercício de uma atividade profissional, ${ }^{65}$ como ocorreu no caso Anderson \& Sons Ltd. $v$. Rhodes (Liverpool) Ltd., ${ }^{66}$ em que se considerou que um agente que afirma a um vendedor de batatas que o seu comitente era solvente, quando não o era, tem um dever de cuidado para com o vendedor. O segundo grupo de casos constitui-se em relações comerciais em que uma parte pode confiar no conhecimento superior e na experiência da contraparte, ${ }^{67}$ como no caso de um locador que foi induzido a celebrar contrato de locação com uma companhia petrolífera porque esta afirmara o grande potencial lucrativo do terreno. ${ }^{68} \mathrm{O}$ terceiro grupo de casos é aquele em que há uma relação jurídica especial entre as partes que justifica o dever de cuidado do declarante. Para identificar este terceiro grupo de casos, os tribunais ingleses recorrem a um teste trifásico consistente em analisar se (i) era previsível ao declarante que o declaratário iria confiar na afirmação falsa; (ii) há proximidade suficiente entre as partes; e (iii) se é razoável o Direito impor um tal dever sobre o declarante. Preenchidos estes três requisitos, configura-se a relação jurídica especial que dá azo à negligent misrepresentation, se o declarante não tiver agido com o cuidado devido ao fornecer a declaração que induz a contraparte a celebrar o negócio. ${ }^{69}$ Por fim, o dever de cuidado pode ser assumido voluntariamente pelo declarante, mesmo que não haja contrato expresso sobre o ponto, caso em que se dispensa o teste trifásico. ${ }^{70} \mathrm{O}$

\footnotetext{
${ }^{64}$ Derry v. Peek (1889) 14 App Cas 337. TREITEL, Günter. The law of contract. 11 $1^{\mathrm{a}}$ ed. Londres: Sweet \& Maxwell, 2003, p. 343-344; CHITTY, Joseph Junior. Chitty on contracts. vol. 1: general principles. $32^{\mathrm{a}}$ ed. Londres: Thomson Reuter, 2015, p. 676; FURMSTON, Michael. Cheshire, Fifoot and Furmston's Law of contract. Oxford: Oxford University Press, 2017, p. 354-355.

65 TREITEL, Günter. The law of contract. $11^{\mathrm{a}}$ ed. Londres: Sweet \& Maxwell, 2003, p. 348-349.

${ }^{66}$ Anderson \& Sons Ltd. v. Rhodes (Liverpool) Ltd. [1967] 2 All E.R. 850.

${ }^{67}$ TREITEL, Günter. The law of contract. $11^{\mathrm{a}}$ ed. Londres: Sweet \& Maxwell, 2003, p. 349.

${ }^{68}$ Esso Petroleum Co Ltd. v. Mardon [1976] Q. B. 801.

69 TREITEL, Günter. The law of contract. $11^{\mathrm{a}}$ ed. Londres: Sweet \& Maxwell, 2003, p. 345-347; STONE, Richard; DEVENNEY, James. The modern law of contract. 12a ed. Abingdon: Routledge, 2017, p. 297. Menciona esse terceiro grupos de casos, porém sem fazer alusão ao teste trifásico: CHITTY, Joseph Junior. Chitty on contracts. vol. 1: general principles. 32a ed. Londres: Thomson Reuter, 2015, p. 698-699.

70 TREITEL, Günter. The law of contract. $11^{\mathrm{a}}$ ed. Londres: Sweet \& Maxwell, 2003, p. 347-348; CHITTY, Joseph Junior. Chitty on contracts. vol. 1: general principles. 32a ed. Londres: Thomson Reuter, 2015, p. 697.
} 
maior exemplo dessa assunção de um dever de cuidado é o famoso caso Hedley Byrne. ${ }^{71}$ Hedley Byrne era uma empresa de publicidade que recebera um grande pedido de um cliente seu, a empresa Easipower Ltd., ao que indagou ao banco Heller \& Partners Ltd. acerca da solvência do seu cliente. A resposta foi afirmativa e Hedley Byrne prestou os serviços a Easipower, a qual, porém, entrou em liquidação logo após. Heller \& Partners não foi condenado a indenizar porque a informação fora prestada com a advertência "without responsibility", mas a House of Lords declarou que, se não houvesse tal exclusão expressa de responsabilidade, seria de considerar-se uma assunção de um dever de agir com cuidado. $^{72}$

$\mathrm{O}$ direito inglês conhece ainda a chamada innocent misrepresentation, aquela em que a parte que presta a declaração falsa não age fraudulentamente nem em violação a dever de cuidado. ${ }^{73}$

Em todos os casos de misrepresentation no direito inglês, são dois os seus efeitos. O primeiro é que o contrato torna-se anulável, abrindo-se a possibilidade de anular o contrato ab initio (rescission) $)^{74}$ à escolha do declaratário enganado, restituindo-se as partes ao estado anterior. ${ }^{75}$ Mas o desfazimento do contrato fica obstado se as partes estiverem impedidas de restituir uma à outra ao estado original. ${ }^{76}$ Esse impedimento se aplica ao desfazimento do contrato em geral, independente da causa do desfazimento. ${ }^{77}$ A razão de ser da regra é impedir que a parte seja colocada em uma posição pior do que se encontrava antes de celebrá-lo. ${ }^{78}$ Este impedimento terá grande impacto na formatação do contrato de

\footnotetext{
${ }^{71}$ Hedley Byrne \& Co Ltd. v. Heller \& Partners Ltd. [1964] A. C. 465.

${ }^{72}$ Veja-se as palavras do juiz Lord Morris of Borth-y-Gest: "I consider that it follows and that it should now be regarded as settled that if someone possessing special skill undertakes, quite irrespective of contract, to apply that skill for the assistance of another person who relies upon such skill, a duty of care will arise".

${ }^{73}$ CHITTY, Joseph Junior. Chitty on contracts. vol. 1: general principles. 32a ed. Londres: Thomson Reuter, 2015, p. 703; FURMSTON, Michael. Cheshire, Fifoot and Furmston's Law of contract. Oxford: Oxford University Press, 2017, p. 363.

${ }^{74}$ Günter Treitel adverte que o termo rescission é polissêmico no direito inglês, podendo ser utilizado tanto para definir a extinção do contrato $a b$ initio, como a resolução do contrato por inadimplemento, em ambos os casos recolocando-se as partes, tanto quanto possível, no lugar em que estariam se o contrato nunca tivesse sido celebrado (TREITEL, Günter. The law of contract. 11 ${ }^{\mathrm{a}}$ ed. Londres: Sweet \& Maxwell, 2003, p. 370).

75 TREITEL, Günter. The law of contract. $11^{\mathrm{a}}$ ed. Londres: Sweet \& Maxwell, 2003, p. 371; ANDREWS, Neil. Contract rules: decoding English Law. Plymouth: Intersentia, 2016, p. 109-110; STONE, Richard; DEVENNEY, James. The modern law of contract. 12a ed. Abingdon: Routledge, 2017, p. 290-291; CHITTY, Joseph Junior. Chitty on contracts. vol. 1: general principles. $32^{\mathrm{a}}$ ed. Londres: Thomson Reuter, 2015, p. 715; FURMSTON, Michael. Cheshire, Fifoot and Furmston's Law of contract. Oxford: Oxford University Press, 2017, p. 364 e 366.

76 FURMSTON, Michael. Cheshire, Fifoot and Furmston's Law of contract. Oxford: Oxford University Press, 2017, p. 370.

77 O’SULLIVAN, Dominic; ELLIOTT, Steven; ZAKRZEWSKI, Rafal. The law of rescission. $2^{\mathrm{a}}$ ed. OXford: Oxford University Press, 2014, p. 365.

${ }^{78}$ O'SULLIVAN, Dominic; ELLIOTT, Steven; ZAKRZEWSKI, Rafal. The law of rescission. $2^{\mathrm{a}}$ ed. OXford:
} 
alienação de participação societária, pois, pela própria natureza do seu objeto, quase sempre é impossível restituir as partes ao mesmo estado.

O segundo efeito é o surgimento de pretensão indenizatória para o declaratário pelos prejuízos causados pela misrepresentation, o que pode ser feito cumulativamente à anulação do contrato ou de forma autônoma, desde que não importe em duplo ressarcimento do dano. ${ }^{79} \mathrm{~A}$ indenização por misrepresentation segue o paradigma da responsabilidade extracontratual (damages in tort), recolocando o declaratário no estado em que este estaria se a declaração falsa não tivesse sido feita. Se a representation for assumida como obrigação contratual, o paradigma de responsabilidade contratual (damages in contract) determina que a parte seja colocada na situação em que estaria se a declaração fosse verdadeira. ${ }^{80} \mathrm{~A}$ exceção fica por conta da innocent misrepresentation, para a qual não existe remédio indenizatório, mas apenas anulação do contrato. ${ }^{81}$ Porém, para evitar que o negócio inteiro seja anulado, o art. 2(2) do Misrepresentation Act de 1967 passou a conferir ao juiz o poder discricionário de, em qualquer caso, manter o contrato e conceder perdas e danos in lieu of rescission, tendo em vista a natureza da misrepresentation e os danos sofridos pelas partes com a anulação do negócio. ${ }^{82}$

No direito americano, a representation também refere-se sempre a fatos passados ou presentes, mas jamais a fatos futuros, pois aí estar-se-ia diante de uma promessa contratual propriamente dita. ${ }^{83}$ Como diz Mark P. Gergen, uma representation oferece confiança (invites reliance) quanto a um determinado enunciado, mas não traz a promessa de tomar alguma atitude no futuro para que tal enunciado venha a ser verdadeiro. ${ }^{84} \mathrm{~A}$

Oxford University Press, 2014, p. 366.

${ }^{79}$ TREITEL, Günter. The law of contract. 11 a ed. Londres: Sweet \& Maxwell, 2003, p. 343; CHITTY, Joseph Junior. Chitty on contracts. vol. 1: general principles. 32 ed. Londres: Thomson Reuter, 2015, p. 675. De forma um pouco diversa, Neil Andrews entende que o dano cumulável com a anulação do negócio são apenas as despesas necessariamente incorridas segundo os termos da operação (ANDREWS, Neil. Contract rules: decoding English Law. Plymouth: Intersentia, 2016, p. 111). De forma contrária, entendem Stone e Devenney, para os quais, no regime do common law, a indenização aplica-se apenas no caso de innocent misrepresentation, pois o escopo da indenização é bastante restrito, vez que limitada aos gastos necessariamente incorridos com a celebração do negócio (STONE, Richard; DEVENNEY, James. The modern law of contract. $12^{\mathrm{a}}$ ed. Abingdon: Routledge, 2017, p. 298).

${ }^{80}$ TREITEL, Günter. The law of contract. $11^{a}$ ed. Londres: Sweet \& Maxwell, 2003, p. 359-360.

${ }^{81}$ CHITTY, Joseph Junior. Chitty on contracts. vol. 1: general principles. $32^{\mathrm{a}}$ ed. Londres: Thomson Reuter, 2015, p. 703

82 TREITEL, Günter. The law of contract. 11a ed. Londres: Sweet \& Maxwell, 2003, p. 357-359; ANDREWS, Neil. Contract rules: decoding English Law. Plymouth: Intersentia, 2016, p. 115

${ }^{83}$ FARNSWORTH, E. Allan. Contracts. $4^{\text {a }}$ ed. Nova Iorque: Aspen, 2004, p. 237. Contra este entendimento tradicional, Mark P. Gergen defende que a responsabilidade por afirmações negligentes e equivocadas deveria ser colocada na problemática contratual (GERGEN, Mark P. Negligent misrepresentation as contract. California Law Review, vol. 101, 2013, p. 989-1011.

${ }^{84}$ GERGEN, Mark P. Negligent misrepresentation as contract. California Law Review, vol. 101, 2013, p. 
representation pode ser feita por meio de qualquer tipo de conduta, mas normalmente é uma afirmação em palavras escritas ou faladas. Tal como no direito inglês, o mero silêncio (nondisclosure) não é sancionado, mas o §161(b) e (c) do Restatement (2nd) of Contracts determina que o silêncio equivale a uma afirmação positiva para os fins da misrepresentation quando a divulgação do fato ou da informação for necessária para impedir que a contraparte celebre o negócio com base em falsa representação da realidade e não seja conforme ao padrão de boa-fé ou de negociação leal não fornecer a informação que elimina o erro, ou em equivocada compreensão do conteúdo ou efeito de um contrato escrito. ${ }^{85}$ Allan Farnsworth ensina ainda que a falha em retificar uma informação verdadeira que se torna falsa por mudança de circunstâncias pode ser considerada misrepresentation, assim como a não divulgação de uma informação quando as partes estão em uma relação de confiança. ${ }^{86}$

A parte só pode exigir os remédios da misrepresentation nos Estados Unidos quando tiver confiado de forma justificada na veracidade da declaração falsa. Assim, se a parte investigou por conta própria os fatos que originaram a declaração falsa e confiou na veracidade dos fatos com base em seu próprio julgamento, não terá pretensão por misrepresentation. ${ }^{87}$ Questão controversa é se o comprador, mesmo tendo ciência da

959.

${ }^{85}$ HOFFER, Stephanie R. Misrepresentation: the restatement's second mistake. University of Illinois Law Review, 2014, vol. 1, p. 127. No comentário oficial do American Law Institute ao §161 do Restatement (2nd) of Contracts, afirma-se que a parte não tem o dever de informar tudo o que sabe à contraparte, mas a não divulgação só tem consequências jurídicas nos casos enumerados no §164 (AMERICAN LAW INSTITUTE. Restatement of the Law second contracts $\S \S 1-177$. Saint Paul: American Law Institute Publisher, 1981, p. 431-432). Veja-se no texto original do Restatement (2nd) of Contracts, §161: "When Non-Disclosure Is Equivalent to an Assertion. A person's non-disclosure of a fact known to him is equivalent to an assertion that the fact does not exist in the following cases only: (a) where he knows that disclosure of the fact is necessary to prevent some previous assertion from being a misrepresentation or from being fraudulent or material. (b) where he knows that disclosure of the fact would correct a mistake of the other party as to a basic assumption on which that party is making the contract and if non-disclosure of the fact amounts to a failure to act in good faith and in accordance with reasonable standards of fair dealing. (c) where he knows that disclosure of the fact would correct a mistake of the other party as to the contents or effect of a writing, evidencing or embodying an agreement in whole or in part. $(d)$ where the other person is entitled to know the fact because of a relation of trust and confidence between them".

${ }^{86}$ FARNSWORTH, E. Allan. Contracts. $4^{\text {a }}$ ed. Nova Iorque: Aspen, 2004, p. 240. Sobre a necessidade de corrigir declarações anteriormente feitas à luz de mudança de circunstâncias, veja-se o comentário oficial ao $\$ 161$, item c, do Restatement (2nd) of Contracts (AMERICAN LAW INSTITUTE. Restatement of the Law second contracts $\S 1$ 177. Saint Paul: American Law Institute Publisher, 1981, p. 432). De forma um pouco diversa, Marvin Chirelstein interpreta o $\$ 162$ do Restatement como uma regra que equipara a não divulgação à misrepresentation toda vez que a não divulgação configurar violação à boa-fé ou disser respeito a uma premissa básica do contrato levada em conta pela outra parte (CHIRELSTEIN, Marvin A. Concepts and case analysis in the law of contracts. $2^{\mathrm{a}}$ ed. Saint Paul: Foundation Press, 2013, p. 90).

${ }^{87}$ FARNSWORTH, E. Allan. Contracts. $4^{\mathrm{a}}$ ed. Nova Iorque: Aspen, 2004, p. 245. Contrariamente a este entendimento comum, Pablo Carrillo entende que mesmo o conhecimento prévio da falsidade da informação não deve, por si só, impedir a ação por misrepresentation. Para o autor, a parte que toma conhecimento da falsidade da informação antes de fechar o negócio pode ter razões negociais suficientes para fechar o negócio 
falsidade da representation, negocia uma indenização específica para tal representation no contrato. Aqui o comprador certamente não terá confiado na representation, pois sabe de antemão que é falsa; contudo, as partes decidem mantê-la no contrato para o comprador poder cobrar uma indenização específica. Seria o comprador merecedor de tutela neste caso? No conhecido caso Hendricks v. Callahan, a decisão da corte federal foi pela perda do direito do comprador de exigir a indenização. ${ }^{88}$

Tampouco se considera justificada a confiança em uma mera opinião do declarante, ou em uma questão de direito ou ainda em uma simples afirmação de intenção subjetiva do declarante. ${ }^{89}$ Porém, a jurisprudência americana impõe o dever de agir com certa diligência para investigar a veracidade das afirmações da contraparte, não se tolerando uma confiança cega em qualquer informação. ${ }^{90}$

O Restatement (2nd) of Contracts distingue apenas duas hipóteses de misrepresentation, em seus §§162-163: fraudulenta (fraudulent misrepresentation) e relevante (material misrepresentation). Na fraudulent misrepresentation, a parte que faz a declaração falsa tem conhecimento de sua falsidade, ou não acredita na veracidade da sua própria declaração, ou a faz descuidadamente, sem ter elementos suficientes para fazê-la (scienter). ${ }^{91}$ Porém, é imprescindível que o declarante tenha também a intenção de enganar. $^{92}$ Já na material misrepresentation, são desnecessárias a ciência de que a afirmação é falsa e a intenção de enganar. Basta que seja relevante, ou seja, que a misrepresentation seja capaz de induzir a contraparte a manifestar seu consentimento ou

mesmo assim e, por isso, não deveria ser penalizada com a perda do remédio da misrepresentation. Assim, apenas quando o desconhecimento da falsidade da informação fosse causado por negligência da parte é que se poderia falar em não incidência da misrepresentation (CARRILLO, Pablo Enrique. Beware of Scylla and Charybdis: stock purchase of privately held companies and the remedies problem under Rule $10 \mathrm{~b}-5$ - what is buyer to do? Tulane Law Review, vol. 72, jun./1998, p. 2119-2130). Em nosso parecer, tal entendimento não merece ser seguido no Brasil. Se a parte tem ciência de que a informação é falsa, não há falsa representação da realidade (o que já obsta o acesso ao erro e dolo) e tampouco prejuízo por falha no dever de informar, já que o pretenso credor da informação acaba obtendo, ainda que por outros meios, a informação.

${ }^{88}$ Hendricks v. Callahan, 972 F.2d (8th Circ. 1992). Veja-se os comentários de Bill Payne em PAYNE, Bill. Representations, reliance and remedies: the legacy of Hendricks v. Callahan. Bench \& Bar of MinnesotaOfficial Publication of the Minnesota State Bar Association, 2005, vol. 62, n. 8.

${ }^{89}$ FARNSWORTH, E. Allan. Contracts. $4^{\text {a }}$ ed. Nova Iorque: Aspen, 2004, p. 247-252.

${ }^{90}$ HOFFER, Stephanie R. Misrepresentation: the restatement's second mistake. University of Illinois Law Review, 2014, vol. 1, p. 132.

${ }^{91}$ A expressão "scienter" é comumente utilizada para indicar que o declarante tem ciência da falsidade de sua declaração. Mas, para os fins do $\$ 162$ do Restatement (2nd) of Contracts, qualquer das 3 hipóteses supra delineadas configuram scienter, conforme consta do próprio comentário oficial (AMERICAN LAW INSTITUTE. Restatement of the Law second contracts $\$ \S 1-177$. Saint Paul: American Law Institute Publisher, 1981, p. 440-441).

92 FARNSWORTH, E. Allan. Contracts. $4^{\text {a }}$ ed. Nova Iorque: Aspen, 2004, p. 243-44; veja-se também o comentário oficial do American Law Institute ao \$162 (AMERICAN LAW INSTITUTE. Restatement of the Law second contracts $§ 1-177$. Saint Paul: American Law Institute Publisher, 1981, p. 439-440). 
que o declarante saiba que, por alguma razão, a declaração tem o potencial de induzir especificamente aquele declaratário a celebrar o contrato. ${ }^{93}{ }^{94}$

As consequências da misrepresentation no direito americano diferem conforme a natureza da misrepresentation. Na material misrepresentation, o enganado pode pedir desfazimento do contrato (rescission) e a consequente restituição dos benefícios e vantagens recebidas de uma parte a outra (Restatement (2nd) of Contracts, §376), ou em dinheiro, se não for mais possível a restituição in natura. ${ }^{95}$

Já a misrepresentation fraudulenta dá ao enganado a opção de desfazer o contrato e pedir a restituição das prestações recebidas ou manter o contrato e pedir apenas indenização dos prejuízos sofridos. A forma de cálculo desses prejuízos varia de estado para estado norte-americano. Alguns estados, como Nova Iorque, adotam o critério out-ofpocket, pelo qual o dano sofrido é igual ao valor pago pelo bem menos o quanto o bem efetivamente vale. ${ }^{96}$ Ou seja, o dano é o quanto se pagou a mais pelo bem em relação a quanto este vale. Outros estados seguem o critério benefit of the bargain, segundo o qual o dano é igual ao valor que o bem teria se as declarações do alienante fossem verdadeiras, menos o valor atual do bem. ${ }^{97}$ As diferenças podem ficar mais claras com um exemplo. Imagine-se que o comprador $\mathrm{C}$ adquire uma casa do vendedor $\mathrm{V}$ por 5 mil, motivado pela afirmação de V de que a casa está livre de infestações de cupins. Após a compra, descobrese que a casa na verdade possui infestações do inseto, o que faz seu valor cair para 3 mil. Pelo critério out-of-pocket, o dano seria calculado da seguinte forma: $5 \mathrm{mil}-3 \mathrm{mil}=2 \mathrm{mil}$. Já pelo benefit of the bargain, se a veracidade da afirmação fizesse a casa valer 10 mil, V teria de pagar a $\mathrm{C}$ a diferença entre $10 \mathrm{mil} \mathrm{e} 3 \mathrm{mil}=7 \mathrm{mil}$. Em adição a esta indenização, o enganado pode pedir ainda punitive damages. ${ }^{98}$

${ }^{93}$ FARNSWORTH, E. Allan. Contracts. $4^{\mathrm{a}}$ ed. Nova Iorque: Aspen, 2004, p. 244; AMERICAN LAW INSTITUTE. Restatement of the Law second contracts $\S \$ 1-177$. Saint Paul: American Law Institute Publisher, 1981, comentário ao $\$ 162$, item c, p. 441.

${ }^{94}$ Stephanie Hoffer discute se a relevância da misrepresentation seria necessária apenas na material misrepresentation ou igualmente na fraudulent misrepresentation. Segundo a autora, mesmo a fraudulent misrepresentation deve induzir e ter a intenção de induzir a outra parte a contratar. Como na maioria dos casos o consentimento da parte ao contrato dificilmente seria induzido por uma misrepresentation sem relevância, a autora conclui que ambos os tipos de misrepresentation exigem que a afirmação falsa seja relevante (HOFFER, Stephanie R. Misrepresentation: the restatement's second mistake. University of Illinois Law Review, 2014, vol. 1, p. 121-122).

${ }^{95}$ FARNSWORTH, E. Allan. Contracts. $4^{\mathrm{a}}$ ed. Nova Iorque: Aspen, 2004, p. 254.

${ }^{96}$ Veja-se Reno v. Bull, 124 N.E. 144, 146 (N.Y. 1919).

${ }^{97}$ Veja-se Lightniing Litho, Inc. v. Danka Indus., Inc., 776 N.E.2d 1238, 1241-1242 (Ind. Ct. App. 2002).

98 STARK, Tina L. Drafting contracts: how and why lawyers do what they do. Nova Iorque: Aspen Publishers, 2007, p. 15-16. 
Em ambos os casos de misrepresentation, a impossibilidade de restituir às partes ao estado anterior impede a alegação de rescission. ${ }^{99}$ Mas note-se que, mesmo na ação de misrepresentation que busca tão somente indenização, em muitas jurisdições norteamericanas a vítima deve comprovar a confiança na representation feita pela outra parte. ${ }^{100}$

Vê-se, assim, que o adquirente de participação societária encontra proteção limitada no instituto da misrepresentation, pois, além de o não-fornecimento de informações sobre a sociedade não configurar misrepresentation em geral, o adquirente ainda teria de fazer prova de que justificadamente confiou na informação prestada, ou que a ausência da informação equivale a uma declaração de fato falsa. Diante da dificuldade de realizar tal prova, o melhor recurso ao adquirente é proteger-se por meio de estipulações contratuais. $^{101}$

\section{A tipologia das cláusulas contratuais no common law}

A distinção entre os terms of the contract e as mere representations é de grande importância no common law, pois permite distinguir entre aquilo a que as partes quiseram outorgar força vinculativa contratual e aquilo que ficou no campo das simples declarações pré-contratuais que não chegam a obrigar as partes ao seu cumprimento. No primeiro caso, as partes estarão sujeitas aos remédios próprios do descumprimento contratual; no segundo, aos remédios explorados acima para a misrepresentation.

À base de toda a construção dos termos do contrato está o acordo das partes. Os direitos inglês e americano partem da ideia de contrato com base na intenção das partes, naquilo que as partes efetivamente prometeram uma à outra e concordaram. ${ }^{102}$ Os termos do contrato são classificados em express terms e implied terms. Em um contrato escrito, os termos expressos estão escritos no próprio contrato ou são a ele incorporados por outro documento escrito, desde que o contrato aceite tal incorporação. Já em um contrato não escrito, a busca pelos termos expressos depende das comunicações entre as partes e dos

\footnotetext{
${ }^{99}$ PERILLO, Joseph. M. Calamari and Perillo on contracts. 5a ed. Saint Paul: West Publishing, 2003, p. 357. 100 AMERICAN BAR ASSOCIATION, Business Law Section. Model stock purchase agreement with commentary. Vol. I. $2^{\text {a }}$ ed. Chicago: ABA Book Publishing, 2010, p. 288.

101 KARAMPATZOS, Antonios G. Der Umfang der Aufklärungspflicht des Verkäufers beim Unternehmenskauf - Insbesondere die so genannte "Non-Reliance"-Klausel. Neue Zeitschrift für Gesellschaftsrecht, 2012, p. 853-854, aduz que a melhor informa de se proteger contra a indução a erro no common law é colocar no contrato as informações repassadas para induzir a outra parte a celebrar o negócio. 102 CARTWRIGHT, John. Contract Law: an introduction to the English Law of contract for the civil lawyer. $3^{\mathrm{a}}$ ed. Oxford, Portland: Bloomsbury, 2016, p. 201; WILLISTON, Samuel. A treatise on the law of contracts. vol. 11. $4^{\mathrm{a}}$ ed atualizada por Richard Lord. Danvers: West Group, 1999, p. 31-33.
} 
meios de prova que as partes puderem trazer ao processo. Já os termos implícitos são aqueles que não foram incluídos expressamente no contrato pelas partes, mas cuja existência pode ser atestada pelo julgador no caso concreto. ${ }^{103}$

Embora essa distinção seja bastante trabalhada no common law, fugiria ao escopo deste estudo descer à análise dos critérios de existência e interpretação de tais termos. Mais importante é analisar a tipologia das cláusulas contratuais construídas no common law, pois afetam diretamente o entendimento da cláusula de declarações e garantias. Fazemos aqui referência às conditions, warranties e indemnities, a seguir analisadas.

\subsection{Conditions}

A expressão "conditions" é polissêmica no common law. Gerard McMeel identifica pelo menos três significados diferentes para as conditions no direito inglês. Em um sentido amplo, conditions são qualquer estipulação que integre o conteúdo do contrato. Equivalente, portanto, aos terms of the contract. Em um segundo sentido, conditions são apenas aquelas cláusulas contratuais às quais as partes outorgam importância tamanha a ponto de o descumprimento de uma condition justificar a resolução do contrato. Neste segundo sentido, a condition pode melhor ser explicada por contraposição a uma warranty, que é uma cláusula contratual que não possui senão importância lateral para a equação de interesses entre as partes. A violação de uma condition autoriza a resolução do contrato, ao passo que a warranty apenas intitula a parte inocente a reclamar indenização. Por fim, em um terceiro sentido, a condition pode ser mencionada como uma disposição que impede a formação do contrato até que se preencha a condition (condition precedent), ou que desfaz o contrato caso venha a implementar-se (condition subsequent), ${ }^{104}$ sentido próximo ao de condições suspensivas e resolutivas no direito brasileiro. Günter Treitel aponta ainda um possível quarto sentido para as conditions no direito inglês, no qual esta organiza a ordem de execução das obrigações das partes no contrato. Por exemplo, a entrega da mercadoria

\footnotetext{
${ }^{103}$ CARTWRIGHT, John. Contract Law: an introduction to the English Law of contract for the civil lawyer. $3^{\mathrm{a}}$ ed. Oxford, Portland: Bloomsbury, 2016, p. 203, 205 e 210.

104 MCMEEL, Gerard. The construction of contracts: interpretation, implication and rectification. $2^{\mathrm{a}}$ ed. Oxford: Oxford University Press, 2011, p. 544-545. Classificação similar pode ser encontrada em CHITTY, Joseph Junior. Chitty on contracts. vol. 1: general principles. 32 ${ }^{\mathrm{a}}$ ed. Londres: Thomson Reuter, 2015, p. 295296 e 1025-1026. Apontando também a polissemia da palavra no direito inglês, FURMSTON, Michael. Cheshire, Fifoot and Furmston's Law of contract. Oxford: Oxford University Press, 2017, p. 203-207
} 
pode ser uma condition precedent para que surja a obrigação do comprador de pagar o preço. ${ }^{105}$

Já no direito americano é mais comum ver-se o emprego de conditions no terceiro e quarto sentidos acima mencionados. Assim, a condition tanto pode ser um evento incerto e alheio ao controle das partes, de cuja implementação depende a obrigação da parte de executar o contrato (e nesse sentido é que o $\$ 224$ do Restament 2 nd of Contracts define a condition), quanto um método de organização da entrega das prestações de parte a parte. ${ }^{106}$ As conditions podem ser utilizadas também para criar procedimentos dentro do contrato para que uma parte possa exigir a execução da obrigação da outra parte, demandando, por exemplo, o envio de notificação à contraparte. ${ }^{107}$ No sentido de obrigação contratual, o direito americano costuma utilizar as expressões covenant ou promise. ${ }^{108}$

Para o escopo deste trabalho releva a compreensão das conditions no segundo sentido mencionado acima, pois permite, de um lado, melhor compreender o significado da cláusula contratual que é seu oposto, as warranties. Adotaremos, a partir de agora, a expressão conditions no sentido de cláusula contratual com fundamental importância para o contrato a ponto de o seu descumprimento justificar a resolução do contrato.

Obviamente a parte não estará autorizada a resolver o contrato apenas em caso de violação de uma condition. A resolução contratual também pode ocorrer se a violação de uma cláusula contratual que não se enquadra como condition nem warranty (os chamados intermediate terms) for suficientemente grave a ponto de justificar a extinção do contrato, ou igualmente se a contraparte se recusar a prestar ou se o contrato contiver disposição específica sobre o direito de resolução. ${ }^{109}$ A função de uma condition será, então, a de estabelecer a presunção prima facie de que a sua violação por si só é suficientemente grave a ponto de autorizar a resolução.

Diz-se prima facie porque em certos casos a violação de uma condition não será tão relevante para o contrato a ponto de justificar a resolução. Em alguns casos, os tribunais

105 TREITEL, Günter. The law of contract. 11 $1^{\mathrm{a}}$ ed. Londres: Sweet \& Maxwell, 2003, p. 788-789.

${ }^{106}$ FERRIEL, Jeffrey; NAVIN, Michael. Understanding contracts. Nova Iorque: Lexis Nexis, 2004, p. 411417; FARNSWORTH, E. Allan. Contracts. $4^{a}$ ed. Nova Iorque: Aspen, 2004, p. 503-504. Enfatizando o uso no terceiro sentido aqui mencionado, HUNTER, Howard O. Modern law of contracts. Vol. 1. West Publishing, 2012, p. 568-572.

${ }^{107}$ FERRIEL, Jeffrey; NAVIN, Michael. Understanding contracts. Nova Iorque: Lexis Nexis, 2004, p. 417.

${ }^{108}$ Essa é a nomenclatura usada, por exemplo, em HUNTER, Howard O. Modern law of contracts. Vol. 1. West Publishing, 2012, p. 568.

${ }^{109}$ MCMEEL, Gerard. The construction of contracts: interpretation, implication and rectification. $2^{\mathrm{a}}$ ed. Oxford: Oxford University Press, 2011, p. 545-546. 
ingleses rejeitaram o pedido de resolução com base em violação de uma condition, porque, embora sendo condition, não tocava à essência do contrato. ${ }^{110}$ É claro que, se as próprias partes classificam determinada cláusula como condition, será difícil encontrar maneira melhor de medir a importância da condition no esquema contratual que a própria vontade das partes. ${ }^{111}$ Mas em outros casos, julgou-se que a resolução por fundamental breach visa a proteger a parte contra prejuízos, ao passo que a resolução por violação de uma condition objetiva promover segurança jurídica às partes que assim estipularam, independente da magnitude da violação. ${ }^{112}$ Pode-se, assim, entender a resolução por desrespeito de uma condition como exceção à regra de resolução por fundamental breach. ${ }^{113}$

A resolução contratual no direito inglês possui basicamente três efeitos. Em qualquer caso, a resolução (i) desobriga as partes de suas obrigações ainda não vencidas ${ }^{114}$ e (ii) obriga a parte culpada a indenizar a outra em lugar da prestação primária. ${ }^{115}$ Porém, pode também (iii) intitular a parte inocente a pedir restituição das prestações entregues em lugar da indenização, mas, se a prestação entregue pela parte inocente for em dinheiro, a falha da parte culpada em oferecer a sua contraprestação deve ser total para que nasça o direito de resolver, ou, ao contrário, se a prestação da parte inocente não for em dinheiro, basta o inadimplemento parcial. ${ }^{116}$ Assim, a regra é que a resolução projete seus efeitos apenas para o futuro, mantendo hígidas as prestações já entregues pelas partes, mas libereas de prestações futuras. ${ }^{117}$ Apenas em determinadas circunstâncias serão desfeitos os

\footnotetext{
${ }^{110}$ Hongkong Fir Shipping Co Ltd. v. Kawasaki Kisen Kaisha Ltd. [1962] 2 Q. B. 26; United Scientific Holdings v. Burnley BC [1978] A. C. 904; TREITEL, Günter. The law of contract. 11 a ed. Londres: Sweet \& Maxwell, 2003, p. 791.

${ }^{111}$ TREITEL, Günter. The law of contract. 11 a ed. Londres: Sweet \& Maxwell, 2003, p. 791-792. No entanto, não só a nomenclatura da cláusula adotada pelas partes, mas também a lei, os precedentes judiciais, a outorga expressa de um direito de resolução em caso de violação podem indicar a presença de uma condition (STANNARD, John E.; CAPPER, David. Termination for breach of contract. Oxford: Oxford University Press, 2014, p. 141-156; ANDREWS, Neil. Contract rules: decoding English Law. Plymouth: Intersentia, 2016, p. 285-287; STONE, Richard; DEVENNEY, James. The modern law of contract. 12a ed. Abingdon: Routledge, 2017, p. 458-460).

112 Bunge Corp v. Tradax Export SA [1981] 1 W. L. R. 711; Lombard North Central plc v. Butterworth [1987] Q. B. 527.

113 TREITEL, Günter. The law of contract. $11^{\mathrm{a}}$ ed. Londres: Sweet \& Maxwell, 2003, p. 791.

114 STANNARD, John E.; CAPPER, David. Termination for breach of contract. Oxford: Oxford University Press, 2014, p. 239.

115 STANNARD, John E.; CAPPER, David. Termination for breach of contract. Oxford: Oxford University Press, 2014, p. 261; ANDREWS, Neil. Contract rules: decoding English Law. Plymouth: Intersentia, 2016 , p. 282; MCMEEL, Gerard. The construction of contracts: interpretation, implication and rectification. $2^{\mathrm{a}}$ ed. Oxford: Oxford University Press, 2011, p. 547.

116 STANNARD, John E.; CAPPER, David. Termination for breach of contract. Oxford: Oxford University Press, 2014, p. 287-299.

117 ANDREWS, Neil. Contract rules: decoding English Law. Plymouth: Intersentia, 2016, p. 281-282; MCMEEL, Gerard. The construction of contracts: interpretation, implication and rectification. $2^{\mathrm{a}}$ ed. Oxford: Oxford University Press, 2011, p. 546-547; CHITTY, Joseph Junior. Chitty on contracts. vol. 1: general
} 
efeitos já produzidos pelo contrato. O credor pode optar por manter o contrato, mas sua aceitação pode ser considerada um indício de que a condition não era tão relevante ao mesmo. ${ }^{118}$

No direito americano, dada a diferença de entendimento quanto ao conceito de condition, a não ocorrência da condition suspende a obrigação da parte até que a condition se implemente ou, se a condition não puder ocorrer de forma definitiva, a parte fica liberada de cumprir sua obrigação. A exceção à regra fica por conta da condition cujo implemento uma das partes obriga-se a fazer acontecer. ${ }^{119}$ A resolução contratual fica sujeita à regra geral de inadimplemento substancial do contrato (material breach), ${ }^{120}$ resguardada a possibilidade de o devedor purgar a mora (cure), sendo que a ausência de probabilidade de purga da mora é requisito do material breach, de acordo com o $\$ 241$ do Restatement (2nd) of Contracts.

\subsection{Warranties}

As warranties, contrariamente às conditions, são promessas contratuais que, por não tocarem matérias fundamentais ao contrato, não dão ensejo à resolução contratual quando de sua violação, mas apenas a indenização ${ }^{121}$ independentemente de culpa. ${ }^{122}$ Porém, é preciso concordar com Gerard McMeel que as warranties não são necessariamente cláusulas de importância secundária na arquitetura contratual, embora esta seja a lição mais corriqueira. As warranties podem ser a cláusula mais importante do negócio, e frequentemente o são em operações envolvendo alienação de participação societária ou estabelecimentos empresariais. Mas mesmo nesse caso as warranties se distinguem por gerar apenas ação de indenização, e esse é o seu traço característico. ${ }^{123}$

principles. $32^{\mathrm{a}}$ ed. Londres: Thomson Reuter, 2015, p. 710.

118 VOSS, Stefan Friedrich. Warranties in Unternehmenskaufverträgen - Struktur und Wirkungsweise angloamerikanischer Gewährleistungskataloge in Unternehmenskaufverträgen, die deutschem Recht unterliegen. Tübingen: MVK Medien Verlag Köhler, 2002, p. 57.

${ }^{119}$ FERRIEL, Jeffrey; NAVIN, Michael. Understanding contracts. Nova Iorque: Lexis Nexis, 2004, p. 418.

${ }^{120}$ FERRIEL, Jeffrey; NAVIN, Michael. Understanding contracts. Nova Iorque: Lexis Nexis, 2004, p. 450 e 478; FARNSWORTH, E. Allan. Contracts. 4ª ed. Nova Iorque: Aspen, 2004, p. 566.

${ }^{121}$ STONE, Richard; DEVENNEY, James. The modern law of contract. 12 ${ }^{\mathrm{a}}$ ed. Abingdon: Routledge, 2017, p. 210; CHITTY, Joseph Junior. Chitty on contracts. vol. 1: general principles. $32^{\mathrm{a}}$ ed. Londres: Thomson Reuter, 2015, p. 1030.

122 VOSS, Stefan Friedrich. Warranties in Unternehmenskaufverträgen - Struktur und Wirkungsweise angloamerikanischer Gewährleistungskataloge in Unternehmenskaufverträgen, die deutschem Recht unterliegen. Tübingen: MVK Medien Verlag Köhler, 2002, p. 62.

${ }^{123}$ MCMEEL, Gerard. The construction of contracts: interpretation, implication and rectification. $2^{\mathrm{a}}$ ed. Oxford: Oxford University Press, 2011, p. 554. Essa essência das warranties foi reafirmada no caso Hong 
É comum a confusão entre warranties e representations quando a declaração feita com o intuito de induzir a pessoa a contratar é posteriormente incluída no contrato, pois aí a declaração de fato, presente ou passado, deixa de ser uma mera declaração indutora do contrato e passa a ser uma própria cláusula contratual, uma obrigação contratual. No direito inglês, a incorporação de uma declaração de fato ao conteúdo do contrato transforma-a em warranty, mas a representation pode subsistir como tal para o efeito de provocar a anulação do negócio. ${ }^{124}$ Em outras palavras, ambos os regimes podem conviver simultaneamente. Ainda que a representation não se incorpore ao negócio como term of the contract, a declaração pode ser interpretada como um pacto lateral de warranty (collateral warranty), se, apreciada sob o prisma do teste objetivo que identifica quais declarações integram o conteúdo do contrato (Introdução supra, n. 2.1), o julgador puder definir que a intenção das partes era elevar a declaração em questão ao posto de promessa contratual. ${ }^{125}$

Em dois casos envolvendo alienação de participação societária, a jurisprudência inglesa firmou o entendimento de que a parte não pode reclamar por violação de warranty se, antes da celebração do negócio, tinha conhecimento da falsidade da warranty. No caso Eurocopy, ${ }^{126}$ o adquirente da totalidade do capital de uma sociedade alegou quebra de warranty por conta de uma informação que não fora divulgada pelo vendedor, mas sua pretensão foi negada com base na alegação do vendedor de que o comprador tinha tomado conhecimento da real situação de fato antes da assinatura do contrato. Já em Infiniteland, ${ }^{127}$ o vendedor de $100 \%$ do capital de uma sociedade não informou corretamente em sua contabilidade a injeção de mais de um milhão de libras em outra sociedade logo antes da venda da companhia ao comprador, que alegou quebra da warranty. O vendedor, porém, demonstrou que a informação tinha sido repassada ao perito contábil que auxiliou o comprador na negociação. A corte de apelação inglesa, embora reconhecendo que o conhecimento do fato obstaria a pretensão por quebra de warranty, acabou acolhendo o

Kong Fir Shipping Ltd. v. Kawasaki Kisen Kaisha Ltd. [1962] 2 Q.B. 26, [1962] 1 All ER 474. Veja-se também FURMSTON, Michael. Cheshire, Fifoot and Furmston's Law of contract. Oxford: Oxford University Press, 2017, p. 207-211.

124 TREITEL, Günter. The law of contract. $11^{a}$ ed. Londres: Sweet \& Maxwell, 2003, p. 805; ANDREWS, Neil. Contract rules: decoding English Law. Plymouth: Intersentia, 2016, p. 100.

${ }^{125}$ MCMEEL, Gerard. The construction of contracts: interpretation, implication and rectification. $2^{\mathrm{a}}$ ed. Oxford: Oxford University Press, 2011, p. 555-556; ANDREWS, Neil. Contract rules: decoding English Law. Plymouth: Intersentia, 2016, p. 99-100.

${ }^{126}$ Eurocopy v. Teesdale [1992] BCLC 1067, CA.

${ }^{127}$ Infiniteland Ltd. v. Artisan Contracting Ltd. [2004] EWHC 955 (Ch). 
pedido do comprador, pois entendeu que o conhecimento do fato pelo contador não pode ser estendido ao comprador.

Na Inglaterra, o art. 53 do Sale of Goods Act de 1979 oferece ao beneficiário da warranty a opção de pedir a redução do preço ou de levantar uma pretensão indenizatória autônoma. Uma das maiores diferenças da warranty para a misrepresentation está na forma de cálculo dos danos gerados pelo seu descumprimento. Como a warranty é uma promessa contratual propriamente dita, o interesse juridicamente protegido do beneficiário da warranty é que o bem possua todas as qualidades prometidas por meio da warranty. Portanto, a indenização visa colocá-lo no estado em que se encontraria se o bem possuísse todas as qualidades prometidas. No caso de uma declaração de fato não estar coberta por proteção contratual, a indenização visa apenas a diferença entre o preço pago e o valor real do bem, sem as qualidades prometidas. ${ }^{128}$ A diferente forma de cálculo dos danos nas duas situações reflete a dicotomia entre interesse positivo e interesse negativo.

A ideia de warranty é um pouco diferente no direito americano. A doutrina comumente define warranty como a promessa contratual de que o bem possui determinadas características, qualidades e quantidade. ${ }^{129} \mathrm{O}$ traço característico que diferencia a warranty de uma representation é que a warranty é sempre uma cláusula contratual e sua violação dá origem a uma pretensão contratual, ao passo que a misrepresentation apenas dá lugar ao desfazimento do negócio ou a uma ação de indenização in tort. ${ }^{130 \_131} \mathrm{Na}$ warranty se assume um comportamento para o futuro e esta é a distinção para a simples representation. A representation é puramente uma asserção de

\footnotetext{
${ }^{128}$ ANDREWS, Neil. Contract rules: decoding English Law. Plymouth: Intersentia, 2016, p. 101.

${ }^{129}$ FERRIEL, Jeffrey; NAVIN, Michael. Understanding contracts. Nova Iorque: Lexis Nexis, 2004, p. 357; HUNTER, Howard O. Modern law of contracts. Vol. 1. West Publishing, 2012, p. 471; CUMMING, Elizabeth. Balancing the buyer's right to recover for precontractual misstatements and the seller's ability to disclaim express warranties. Minnesota Law Review, vol. 76, mai./1992, p. 1192.

${ }^{130}$ Stevenson v. B.B. Kirkland Seed Co., 180 S.E. 197, 200 (S.C. 1935); Hecht v. Components Int'1, Inc., 867 N.Y.S.2d 889, 895-96 (Sup. Ct. 2008); BAINBRIDGE, Stephen M. Mergers and acquisitions. $3^{\text {a }}$ ed. Nova Iorque: Foundation Press, 2012, p. 79; WEST, Glenn D.; LEWIS JR., W. Benton. Contracting to avoid extracontractual liability - can your contractual deal ever really be the "entire" deal? The business lawyer, vol. 64 (agosto-2009), p. 1008-1009; GELTMAN, Elizabeth Glass. Shifting the environmental risk: a guide to drafting contracts and structuring transactions. Chicago: ABA Publishing, 1999, p. 133.

${ }^{131}$ Contra esse posicionamento, WILLISTON, Samuel. A treatise on the law of contracts. vol. 18. $4^{\mathrm{a}}$ ed atualizada por Richard Lord. Danvers: West Group, 1999, p. 175-178 (citando jurisprudência), afirma que uma warranty pode ser uma simples afirmação de fato feita para induzir a outra parte a celebrar o contrato. Mas isso talvez possa ser explicado pelo fato de que o antigo direito inglês não diferenciava representations de warranties, mesmo quando estas estivessem escritas no contrato, tratando ambas como afirmações de fato que induzem a parte a contratar e, portanto, qualificando sua violação como misrepresentation. Sobre a matéria veja-se WEST, Glenn D.; LEWIS JR., W. Benton. Contracting to avoid extra-contractual liability can your contractual deal ever really be the "entire" deal? The business lawyer, vol. 64 (agosto-2009), p. 1009-1010.
} 
fato que induz confiança; na warranty, a existência ou não-existência do fato afirmado se projeta para o futuro, na medida em que a parte assume responsabilidade em contrato pela afirmação. ${ }^{132}$ Porém, tal como no direito inglês, muitos tribunais americanos aceitam a existência de uma pretensão por misrepresentation em caso de falsidade de uma warranty, se satisfeitos seus requisitos de culpabilidade, relevância e confiança. ${ }^{133}$

As warranties no direito americano podem ser expressas ou implícitas. Como warranties expressas contam afirmações de fato sobre as qualidades ou condições do objeto do contrato. ${ }^{134}$ Já as implícitas independem de estipulação expressa pelas partes, porém seu conteúdo varia conforme a jurisprudência de cada estado norte-americano. ${ }^{135}$ Característica importante das warranties é que qualquer elemento de fato, seja ele presente, passado ou futuro, pode ser objeto de proteção contratual. ${ }^{136}$ Isso confere ao sistema das warranties uma extensão bem maior que o regime de vícios redibitórios em muitos países de civil law, onde a estreiteza do conceito de vício muitas vezes limita a liberdade das partes para incluir matérias em seu âmbito de proteção.

Sendo ambos os tipos de cláusula baseados em afirmações de fato sobre as qualidades e quantidade da coisa, Elizabeth Glass Geltman aponta a diferença entre ambas nos seguintes termos: "[a] distinção entre uma representation e uma warranty é sutil: uma representation é uma declaração ou asserção de determinado fato, enquanto que a warranty é uma promessa de que a declaração ou asserção é verdadeira" (tradução livre). ${ }^{137}$

132 GERGEN, Mark P. Negligent misrepresentation as contract. California Law Review, vol. 101, 2013, p. 990, nota de rodapé n. 163 (citando Williston).

133 Ainger v. Mich. Gen. Corp., 476 F. Supp. 1209, 1225 (S.D.N.Y. 1979); WEST, Glenn D.; LEWIS JR., W. Benton. Contracting to avoid extra-contractual liability - can your contractual deal ever really be the "entire" deal? The business lawyer, vol. 64 (agosto-2009), p. 1009-1010.

${ }^{134}$ Shippen v. Bowen, 122 U.S. 575, 581, 7 S. Ct. 1283, 30 L. Ed. 1171 (1887); HUNTER, Howard O. Modern law of contracts. Vol. 1. West Publishing, 2012, p. 472.

${ }^{135}$ HUNTER, Howard O. Modern law of contracts. Vol. 1. West Publishing, 2012, p. 473.

${ }^{136}$ VOSS, Stefan Friedrich. Warranties in Unternehmenskaufverträgen - Struktur und Wirkungsweise angloamerikanischer Gewährleistungskataloge in Unternehmenskaufverträgen, die deutschem Recht unterliegen. Tübingen: MVK Medien Verlag Köhler, 2002, p. 66; SERFILIPPI, Claude S. A New York lawyer in London: representations and warranties in acquisition agreements - what's the big deal? Artigo publicado no site Lexology, disponível em https://www.lexology.com/library/detail.aspx?g=1d954834-a35d-4470-bfa2bfee233afe41. Acesso em 23 de maio de 2018.

${ }^{137}$ GELTMAN, Elizabeth Glass. Shifting the environmental risk: a guide to drafting contracts and structuring transactions. Chicago: ABA Publishing, 1999, p. 133-134, no original "[t]he distinction between a representation and a warranty is slight: a representation is a statement or assertion of fact, while a warranty is a promise that the statement or assertion is true". No mesmo sentido, STARK, Tina L. Drafting contracts: how and why lawyers do what they do. Nova Iorque: Aspen Publishers, 2007, p. 13; ROSENBAUM, Judith A. Transactional drafting: teaching tips. Tennessee Journal of Business Law, n. 14, Transactions, p. 594-595; RENNA, Luca. Compravendita di partecipazioni sociali. Dalla lettera di intenti al closing. Bologna: 
As warranties podem ter sua fonte no direito costumeiro (warranties at common law) ou no direito legislado (statutory warranties). No direito costumeiro, geralmente aceita-se a existência de warranties implícitas quanto à titularidade do direito transferido (warranty of title), adequação da coisa para seu uso ordinário (warranty of merchantability) e para um uso específico conhecido do alienante (warranty of fitness for a particular purpose). Em se tratando de aquisição de imóveis, aceita-se também uma warranty de habitabilidade. ${ }^{138}$

Para as warranties previstas em lei, o Uniform Commercial Code possui regulação detalhada no seu Artigo 2 que abrange transações envolvendo quaisquer mercadorias. ${ }^{139}$ Porém, a negociação de quotas e ações não se submete a esta regulação do Uniform Commercial Code. ${ }^{140}$ A jurisprudência, de uma forma geral, inclui tais operações no âmbito do Artigo 8 do UCC, ${ }^{141}$ que regula a emissão, transferência e registro de valores mobiliários (investment securities), mas não possui regras tão detalhadas sobre warranty, limitando-se a outorgar uma garantia de legitimidade do alienante e de validade do título transferido (UCC, §8-108).

Seja no direito costumeiro ou no legislado, a violação de uma warranty torna o devedor responsável independentemente de culpa, ${ }^{142}$ ao contrário das normas que regulam a misrepresentation. Mas, em determinados estados, o devedor pode se exonerar de

\footnotetext{
Zanichelli, 2015, p. 181.

${ }^{138}$ HUNTER, Howard O. Modern law of contracts. Vol. 1. West Publishing, 2012, p. 480-490.

${ }^{139}$ Sob a rubrica do Artigo 2, são warranties previstas em todo contrato: (i) o alienante possui bom título e pode transferir a coisa (title warranty); (ii) se o alienante for um comerciante profissional do tipo de coisa que está a alienar, há warranty de que a coisa corresponde à descrição do contrato e é própria ao uso ordinário próprio àquele tipo de coisa, (merchantability warranty); e (iii) se o alienante tiver condições de saber que o bem se destina a um uso diverso do ordinário, há warranty de que a coisa presta-se ao uso específico. Além disso, podem ser previstas outras warranties específicas pelo alienante (QUINN, Thomas. Quinn's uniform commercial code commentary and law digest. Vol. 1. West Publishing, 2002, p. 395-396, 481-482, 570-571 (Article 2)).

${ }^{140}$ HUNTER, Howard O. Modern law of contracts. Vol. 1. West Publishing, 2012, p. 496.

141 A discussão sobre o enquadramento de ações e quotas de companhias fechadas parece pender para o entendimento que as inclui entre os valores mobiliários para os fins do Artigo 8 do UCC após os precedentes United Ind. Ins. Agencies Inc. v. Bank of Honolulu, 6 Hawaii App. 222, 718 P.2d 1097, 1 U.C.C. Rep. Serv. 2d 866 (1986); Cambron v. Moyer, 519, N.W.2d 381, 25 U.C.C. Rep. Serv. 2d 218 (Iowa 1994); Jennison v. Jennison, 346 Pa. Super. 47, 99 A.2d 302, 41 U.C.C. Rep. Serv. 585 (1985); Bahre v. Pearl, 595 A.2d 1027, 16 U.C.C. Rep. Serv. 2d 780 (Me. 1991). Contra: Blasingame v. American Materials, Inc., 654 S.W.2d 659, 35 U.C.C. Rep. Serv., 1610 (Tenn. 1983); Rhode Island Hosp. v. Collins, 117 R.I. 535, 368 A.2d 1225, 21 U.C.C. Rep. Serv. 619 (1977).

${ }^{142}$ WILLISTON, Samuel. A treatise on the law of contracts. vol. 18. $4^{\mathrm{a}}$ ed atualizada por Richard Lord. Danvers: West Group, 1999, p. 190-193, citando farta jurisprudência antes e após a entrada em vigor do Uniform Commercial Code; CUMMING, Elizabeth. Balancing the buyer's right to recover for precontractual misstatements and the seller's ability to disclaim express warranties. Minnesota Law Review, vol. 76, mai./1992, p. 1194
} 
responsabilidade comprovando que o credor tinha conhecimento da falsidade da warranty quando celebrou o contrato. ${ }^{143}$

As sanções aplicáveis à violação da warranty no direito americano normalmente são as mesmas do direito inglês: indenização in contract pelos danos sofridos, mas não autoriza a resolução do contrato. Os danos são calculados segundo a fórmula benefit of the bargain (sobre a fórmula, veja-se Introdução supra, n. 3). ${ }^{144}$ No regime do Uniform Commercial Code, a violação de warranties pode autorizar outros remédios, como rejeição da coisa e até mesmo desfazimento do contrato (\$2-601 e ss.), sua sanção variando conforme a natureza e a gravidade da violação, podendo as partes inclusive definir em contrato os remédios aplicáveis. ${ }^{145} \mathrm{Ou}$, nas palavras de Glenn West e Benton Lewis, " $a$ warranty é executada como qualquer outra obrigação ou acordo contratual, geralmente independente da intenção, relevância ou confiança [na sua veracidade]" (tradução livre). ${ }^{146}$

\subsection{Indemnities}

No direito inglês, a indemnity é o acordo por meio do qual uma das partes promete proteger e manter a outra parte indene de quaisquer perdas oriundas de um determinado evento especificado ou conjunto de eventos. ${ }^{147} \mathrm{~A}$ indemnity abstrai do conceito de dano e promove o pagamento de uma soma "pound-for-pound" ao beneficiário no montante da

${ }^{143}$ Jackson v. Russell, 498 N.E.2d 22 (Ind. Ct. App. 1986); Pegasus Management Co., Inc. v. Lyssa, Inc., 995 F. Supp. 29 (D. Mass. 1998). A discussão é bastante viva nos Estados Unidos e, em última análise, é a razão pela qual surgiram na prática as cláusulas de sandbagging. Muitos estados exigiam o requisito de reliance para que a vítima do inadimplemento pudesse exigir os remédios da warranty, requisite esse que caía por terra quando a parte tomava conhecimento da falsidade da warranty antes de celebrar o contrato. Para uma análise da jurisprudência americana neste sentido, veja-se: WHITEHEAD, Charles K. Sandbagging: default rules and acquisition agreements. Delaware journal of corporate law, 2011, vol. 36, p. 1081-1115; MIZIOLEK, Aleksandra; ANGELAKOS, Dimitrios. Contract drafting: sandbagging: from poker to the world of mergers and acquisitions. Michigan Bar Journal, 2013, vol. 92, p. 30-34. Já Sidney Kwestel argumenta que a questão passa por saber se a parte lesada pelo inadimplemento da warranty "comprou" a promessa contractual de warranty ou a ela renunciou e quais os elementos de prova que podem ser utilizados nesse interim, em vista da parol evidence rule, KWESTEL, Sidney. Express warranty as contractual - the need for a clear approach. Mercer Law Review, 2002, n. 53, p. 557-580.

144 STARK, Tina L. Drafting contracts: how and why lawyers do what they do. Nova Iorque: Aspen Publishers, 2007, p. 13 e 15.

${ }^{145}$ FERRIEL, Jeffrey; NAVIN, Michael. Understanding contracts. Nova Iorque: Lexis Nexis, 2004, p. 358359.

${ }^{146}$ WEST, Glenn D; LEWIS JR., W. Benton. Contracting to avoid extra-contractual liability - can your contractual deal ever really be the "entire" deal? The business lawyer, vol. 64 (agosto-2009), p. 1009. Lê-se no original: "Indeed, a warranty is strictly enforced like any other contractual covenant or agreement, generally without regard for intention, materiality, or reliance".

${ }^{147}$ COURTNEY, Wayne. Contractual indemnities. Oxford: Hart Publishing, 2014, p. 3; MCMEEL, Gerard. The construction of contracts: interpretation, implication and rectification. $2^{\mathrm{a}}$ ed. Oxford: Oxford University Press, 2011, p. 563. 
perda por ele sofrida, mesmo que a perda não venha a configurar dano em sentido jurídico no caso concreto. ${ }^{148}$ A indemnity, portanto, está atrelada a dados objetivos: o evento que a dispara e o ressarcimento da perda que ela proporciona definem-se no contrato e abstraem de outros requisitos. A obrigação de ressarcir a perda é decorrência única e exclusiva da ocorrência do fato coberto pela indemnity, pura e simplesmente.

Em uma aquisição de participação societária, a estipulação de indemnities tem o mérito de contornar a tortuosa questão de saber se a perda sofrida pela sociedade-alvo reverte totalmente em diminuição do valor das ações, o que na maioria das vezes não ocorre. Se uma deterioração de estoques da sociedade no valor de $\mathrm{R} \$ 1$ milhão reflete-se numa desvalorização das ações de apenas R 600 mil, isso não afeta a obrigação do alienante de pagar à sociedade toda a extensão dos $\mathrm{R} \$ 1$ milhão, pois a indemnity não se prende ao dano, que pode nem mesmo existir, mas liga-se às perdas decorrentes do evento especificado.

Em monografia especificamente dedicada ao assunto na Inglaterra, Wayne Courtney aponta que a indemnity pode ser preventiva quando o pagador antecipa-se a uma perda do beneficiário - como ocorre em alienações de participação societária quando o adquirente da sociedade tem de arcar com o custo de uma demanda de terceiro e o pagador da indemnity fornece ao beneficiário a quantia necessária para fazer frente a tal despesa -, ou compensatória quando a quantia é entregue ao beneficiário após a consumação da perda - o que também pode ser exemplificado com o contrato de alienação de participação societária que dispõe que a perda só será ressarcida após o desembolso pelo beneficiário. ${ }^{149}$

Segundo Wayne Courtney, embora as cláusulas de indemnities sejam variáveis em seu conteúdo (podendo até mesmo ter origem em outras fontes que não o contrato) ${ }^{150}$ a essência comum a todas elas é a ideia de "proteção exata" (exact protection) contra a perda. A proteção exata se desdobra em três elementos: se for corretamente executada, a indemnity mantém o beneficiário propriamente seguro contra a perda; fá-lo na exata medida da perda, nem acima nem abaixo dela, o que leva a deduzir do valor da indemnity eventuais ganhos obtidos a partir do evento que a dispara; mas a indemnity limita-se às

\footnotetext{
148 VON BISMARCK, Nilufer. Corporate acquisitions and merger in the United Kingdom. Zuidpoolsingel: Wolters Kluwer, 2013, p. 40.

${ }^{149}$ COURTNEY, Wayne. Contractual indemnities. Oxford: Hart Publishing, 2014, p. 19-29.

150 COURTNEY, Wayne. Contractual indemnities. Oxford: Hart Publishing, 2014, p. 4-6; MCMEEL, Gerard. The construction of contracts: interpretation, implication and rectification. $2^{\mathrm{a}}$ ed. Oxford: Oxford University Press, 2011, p. 562-563.
} 
perdas ocasionadas pelo evento especificado pelas partes, não a qualquer perda decorrente de qualquer evento, ou seja, ela deve ser compreendida apenas dentro de um escopo restrito de perdas ressarcíveis (scope of indemnity). ${ }^{151}$

As partes possuem liberdade para definir a extensão da indemnity. Podem pactuar, por exemplo, que o ressarcimento abrange perdas, danos por ricochete, despesas, gastos com advogados, pretensões, demandas de terceiro etc. Seu escopo é, portanto, flexível. ${ }^{152}{ }^{153}$ Wayne Courtney refere que a indemnity deve idealmente contemplar três elementos, a saber: a descrição do evento que ativa a indemnity, o conector semântico indicando que a parte deverá indenizar ou salvaguardar a outra parte das consequências de tal evento e a definição das consequências geradas por tal evento que se encontram no âmbito de proteção da indemnity (perdas, danos, honorários, danos por ricochete etc). ${ }^{154}$ Assim, embora não precise estar vinculada à ideia de violação contratual, nada impede que o fato ativador da indemnity seja justamente a violação de alguma disposição contratual e sua amplitude se identifique com as consequências negativas de tal fato.

Como abstrai do conceito de dano, uma das vantagens da indemnity em relação à warranty no direito inglês é que o ressarcimento da perda não é afetado pelo conhecimento do adquirente quanto à inconsistência no patrimônio da sociedade. ${ }^{155}$ Outra vantagem que pode ser imaginada é conferir o ressarcimento da perda diretamente à sociedade-alvo que, em tese, não poderia ser indenizada por violação do contrato, já que dele a sociedade-alvo não é parte. ${ }^{156}$ Essa é, inclusive, a razão pela qual as indemnities começaram a ser

${ }^{151}$ COURTNEY, Wayne. Contractual indemnities. Oxford: Hart Publishing, 2014, p. 7-8.

${ }^{152}$ COURTNEY, Wayne. Contractual indemnities. Oxford: Hart Publishing, 2014, p. 57-59.

${ }^{153}$ Porém, se o beneficiário não puder provar nenhum tipo de perda, Nilufer von Bismarck chama covenant a cláusula que prevê o pagamento de uma soma pela violação de uma warranty. Isso pode ser exemplificado com a aquisição de uma sociedade que possui um imóvel avaliado em $\mathrm{R} \$ 10$ milhões, mas, após a aquisição, descobre-se que o imóvel vale apenas $\mathrm{R} \$ 5$ milhões. A sociedade não terá sofrido nenhuma perda, pois o imóvel sempre esteve em seu patrimônio e o valor sempre foi o mesmo. E o adquirente da participação pode não conseguir comprovar nenhuma diminuição no valor de sua participação em decorrência do evento. Neste caso, a responsabilidade do alienante não será propriamente por uma perda, mas sim por um covenant de ressarcimento de qualquer diminuição de valor atribuível à violação da warranty sobre as condições do imóvel (VON BISMARCK, Nilufer. Corporate acquisitions and merger in the United Kingdom. Zuidpoolsingel: Wolters Kluwer, 2013, p. 41). Em nossa opinião, a questão parece ser de mera nomenclatura, pois, tendo escopo flexível, nada obstaria que a matéria fosse abrangida por indemnity.

${ }^{154}$ COURTNEY, Wayne. Contractual indemnities. Oxford: Hart Publishing, 2014, p. 58.

${ }^{155}$ SINCLAIR, Neil. Sinclair on warranties and indemnities on share and asset sales. $9^{\mathrm{a}}$ ed. Londres: Sweet \& Maxwell, 2014, p. 5; VON BISMARCK, Nilufer. Corporate acquisitions and merger in the United Kingdom. Zuidpoolsingel: Wolters Kluwer, 2013, p. 40.

${ }^{156}$ Sinclair ressalta que as warranties promovem o efeito de uma redução do preço e, por isso, tocam apenas comprador e vendedor da participação societária, deixando a sociedade-alvo desprotegida (SINCLAIR, Neil. Sinclair on warranties and indemnities on share and asset sales. $9^{\mathrm{a}}$ ed. Londres: Sweet \& Maxwell, 2014, p. $3)$. 
utilizadas em aquisições de participação societária na Inglaterra, pois muitas operações acabavam impondo à companhia a obrigação de recolher impostos por um benefício que havia sido auferido pelo acionista. Então começou-se a conferir ressarcimento das perdas diretamente à companhia por meio de indemnities. ${ }^{157}$

No direito americano, a concepção de indemnity assemelha-se à do direito inglês abordada acima, qualificando-se como uma obrigação de pagar uma soma em dinheiro ao beneficiário pela simples ocorrência de um determinado evento. A indemnification é um método pelo qual uma parte transfere à outra parte uma perda pela qual a primeira seria responsável, ou seja, opera-se uma transferência de um risco de uma parte a outra. ${ }^{158}$ Distingue-se, assim, da indenização, porque não visa compensar a parte por um dano sofrido em sentido jurídico, mas esgota-se na asserção objetiva da ocorrência de um fato, o qual desencadeia o efeito de pagar a soma em pecúnia. ${ }^{159}$ Historicamente, o termo indemnify surgiu no common law para descrever o pedido de reembolso feito pelo autor contra o réu quanto a pagamentos feitos por aquele a terceiros, ou seja, em situações de third-party claims. ${ }^{160}$ No entanto, o uso moderno da expressão "indemnify" evoluiu para significar qualquer pagamento devido por violação ao contrato, independentemente de sua fonte. ${ }^{161}$ Normalmente a indemnity vem traduzida na expressão "hold harmless", mas ambas podem ser consideradas sinônimas. ${ }^{162}$

Entre as vantagens de se estipular uma indemnity, cite-se que (i) as partes podem incluir no âmbito de proteção da indemnity uma quantidade maior de indivíduos do que

\footnotetext{
${ }^{157}$ SINCLAIR, Neil. Sinclair on warranties and indemnities on share and asset sales. $9^{\mathrm{a}}$ ed. Londres: Sweet \& Maxwell, 2014, p. 3-4.

158 YOUNGBLOOD JR., D. Hull; FLOCOS, Peter N. Drafting and enforcing complex indemnification provisions. The practical lawyer, ago./2010, p. 22.

${ }^{159}$ WEST, Glenn D.; DURAN, Sarah G. Reassessing the "consequences" of consequential damage waivers in acquisition agreements. The business lawyer, vol. 63, mai./2008, p. 786.

160 AMERICAN BAR ASSOCIATION, Business Law Section. Model stock purchase agreement with commentary. Vol. I. $2^{\text {a }}$ ed. Chicago: ABA Book Publishing, 2010, p. 309.

${ }^{161}$ AMERICAN BAR ASSOCIATION, Business Law Section. Model stock purchase agreement with commentary. Vol. I. $2^{\text {a }}$ ed. Chicago: ABA Book Publishing, 2010, p. 309.

${ }^{162}$ Assim as trata, por exemplo, Bryan Garner (GARNER, Bryan A. Indemnify and hold harmless; save harmless. 15 Green Bag, 2d 17) e o contrato-modelo do American Bar Association (AMERICAN BAR ASSOCIATION, Business Law Section. Model stock purchase agreement with commentary. Vol. I. $2^{\mathrm{a}}$ ed. Chicago: ABA Book Publishing, 2010, p. 303). Nesse mesmo sentido são também as decisões dos tribunais americanos em Majkowski v. American Imaging Management, LLC, 913 A.2d 572, 588-89 (Del. Ch. 2006); Paniaguas v. Aldon Companies, Inc., 2:04-CV-468-PRC, 2006 WL 2788585 (N.D. Ind. Sept. 26, 2006); Consult Urban Renewal Dev. Corp. v. T.R. Arnold \& Assoc., Inc., CIV A 06-1684 WJM, 2007 WL 1175742 (D.N.J. Apr. 19, 2007); In re Marriage of Ginsberg, 750 N.W.2d 520, 522 (Iowa 2008). A corte de apelação da Califórnia, no entanto, no julgamento de Queen Villas Homeowners Association v. TCB Property Management, 56 Cal. Rptr. 3d 528, 534 (Cal. Ct. App. 2007), cunhou a distinção de que indemnify seria uma postura ativa de ressarcir a outra parte por um dano, enquanto que hold harmless significaria uma postura defensiva de impedir que algum dano chegue ao beneficiário da cláusula.
} 
seria possível pelas regras de direito comum, inclusive partes não-signatárias, como empresas subsidiárias, controladoras, diretores etc.; (ii) as partes podem ampliar ou reduzir a gama de perdas ressarcíveis; (iii) as partes podem reduzir as incertezas sobre como se dará o procedimento de ressarcimento, como entrega de notificações, prazos de resposta etc.; (iv) a indemnity pode induzir a parte a prestar declarações de forma mais correta se souber que a falsidade da declaração disparará uma indemnity mais severa que o regime do direito comum. ${ }^{163}$

\section{A cláusula de declarações e garantias}

Analisada a estrutura básica das representations, warranties e indemnities no common law, podemos passar à cláusula de declarações e garantias propriamente dita, a chamada representations and warranties clause. Há mais de uma explicação para sua origem no direito americano.

Uma explicação possível é que as representations referem-se a fatos passados ou presentes, ao passo que as warranties referem-se a fatos futuros. ${ }^{164}$ Essa afirmação pode ser entendida sob a perspectiva de que as warranties são promessas contratuais propriamente ditas, por isso se referem ao futuro, pois não é possível se obrigar a fazer alguma coisa no passado. Em outras palavras, as representations seriam declarações de que determinados fatos existem no presente ou existiram no passado, ao passo que as warranties seriam promessas contratuais para o futuro de que tais declarações sobre determinados fatos são verdadeiras. Mas separar declarações sobre o passado daquelas sobre fatos futuros acaba não tendo relevância prática, razão pela qual comentaristas tratam tal separação como um incômodo à elaboração do contrato. ${ }^{165}$ Embora exista de fato uma diferença ontológica entre representations e warranties do ponto de vista do momento

163 YOUNGBLOOD JR., D. Hull; FLOCOS, Peter N. Drafting and enforcing complex indemnification provisions. The practical lawyer, ago./2010, p. 24-25.

164 LEVINE, Mark L. Including representations and warranties in contracts. New York law journal, 20.1.1989, p. 1; BAINBRIDGE, Stephen M. Mergers and acquisitions. $3^{\text {a }}$ ed. Nova Iorque: Foundation Press, 2012, p. 79; PETTARIN, Guido Germano. Acquisizione, fusione e scissione di società. Milão: Giuffrè, 1992 , p. 37. Na Itália, Giovanni Iorio também entende ser esta a distinção entre as representations e as warranties, porém afirma que a distinção não se impõe na prática contratual italiana (IORIO, Giovanni. Struttura e funzioni delle clausole di garanzia nella vendita di partecipazioni sociali. Milão: Giuffrè, 2006, p. 4).

${ }^{165}$ BAINBRIDGE, Stephen M. Mergers and acquisitions. $3^{\mathrm{a}}$ ed. Nova Iorque: Foundation Press, 2012, p. 79 ("separating them explicitly in an acquisition agreement is a drafting nuisance, and the legal import of the separation has been all but eliminated"). No mesmo sentido, HANKE, Kerstin; SOCHER, Oliver. Fachbegriffe aus M\&A und Corporate Finance: die Gestaltung des Unternehmenskaufvertrags. Neue juristische Wochenschrift, 2010, p. 1576; AMERICAN BAR ASSOCIATION, Business Law Section. Model stock purchase agreement with commentary. Vol. I. $2^{a}$ ed. Chicago: ABA Book Publishing, 2010, p. 77. 
temporal a que cada uma se refere, como as partes em um contrato de alienação de participação societária acabam dando a ambas o mesmo tratamento jurídico, a díade representations and warranties merece ser tratada como uma fattispecie única, não se justificando, em nossa opinião, a separação. ${ }^{166}$

Como visto, a maior diferença entre os institutos da misrepresentation e da warranty é que esta outorga pretensão contratual, ao passo que aquela confere pretensão extracontratual em caso de falsidade das declarações. À primeira vista soa estranho que uma cláusula contratual intitule-se "representations", que constituem base tão somente para responsabilidade extracontratual. Mas isto pode explicar-se pela evolução dos institutos no common law americano.

Tradicionalmente, os tribunais americanos não tratavam afirmações fáticas sobre as qualidades da coisa como uma promessa contratual, mas, em vez disso, como meras declarações quanto ao "predicado fático" do contrato, que podiam ser acionadas por meio de uma misrepresentation, mas não como warranty - nem mesmo quando tais afirmações estivessem escritas no corpo do próprio contrato. ${ }^{167} \mathrm{Em}$ consequência disso, seguindo o direito costumeiro da misrepresentation, os tribunais exigiam prova da confiança (reliance) da parte inocente na declaração falsa para atribuir-lhe os remédios da anulação do contrato (rescission) ou indenização por responsabilidade extracontratual. Isso acabava impedindo o acesso de muitos compradores a quaisquer tipos de remédios quando não conseguiam comprovar a reliance, seja porque sabiam da falsidade da declaração, porque duvidaram da sua veracidade ou porque contrataram por outras razões determinantes que não especificamente a declaração que depois se descobriu falsa. ${ }^{168}$

Essa é a razão porque passou-se a incluir nas cláusulas de representations que o declarante também garantia (“... and warrants”) a veracidade das declarações, pois muitos causídicos entendiam que a warranty teria o condão de transformar a mera afirmação de fato em uma promessa contratual de que as declarações eram verdadeiras. Com isto, seria

\footnotetext{
166 Veja-se PISTORELLI, Roberto. Le garanzie "analitiche" sulle voci della situazione patrimoniale di riferimento. in: Acquisizioni di società e di pacchetti azionari di riferimento, a cura di BONELLI, Franco e DE ANDRÈ, Mauro (orgs.) Milão: Giuffrè, 1990, p. 158-159, julgando inadequada a ideia de que a distinção entre representations e warranties se justifique por referirem-se a fatos passados ou presentes e fatos futuros. ${ }^{167}$ WEST, Glenn D.; LEWIS JR., W. Benton. Contracting to avoid extra-contractual liability - can your contractual deal ever really be the "entire" deal? The business lawyer, vol. 64 (agosto-2009), p. 1009; WEST, Glenn D.; SHAH, Kim M. Debunking the myth of the sandbagging buyer: when sellers ask buyers to agree to anti-sandbagging clauses, who is sandbagging whom? The M\&A lawyer, vol.11, n. 1, 2007, p. 4.

${ }^{168}$ WEST, Glenn D.; SHAH, Kim M. Debunking the myth of the sandbagging buyer: when sellers ask buyers to agree to anti-sandbagging clauses, who is sandbagging whom? The M\&A lawyer, vol.11, n. 1, 2007, p. 4.
} 
conferida ao comprador uma pretensão autônoma e independente, com base no contrato, por violação de warranties, independente de a falsidade da mesma declaração preencher ou não os requisitos da misrepresentation. Assegurava-se, assim, remédios de ambos os institutos. ${ }^{169}$ Essa a origem da expressão representations and warranties.

Tina Stark refere cinco razões para se incluir ambas representations e warranties em um contrato: (i) a parte terá a possibilidade de desfazer o contrato e restituir as prestações se forem prestadas representations falsas; (ii) a parte garante a possibilidade de pedir punitive damages se for alvo de misrepresentation fraudulenta; (iii) a parte mantém seu direito a indenização por quebra de warranty se não conseguir provar confiança na declaração falsa; (iv) se o estado americano em questão segue a regra de danos out-ofpocket para indenização por misrepresentation fraudulenta, a parte pode ainda assim pedir a indenização benefit of the bargain pelo regime da warranty; e (v) recorrendo ao regime da warranty, a parte fica dispensada de provar a intenção de enganar da fraudulent misrepresentation. ${ }^{170}$ No mesmo sentido, Frank Dawson e Stella Styllis entendem que é útil manter a cláusula de representations ao lado das warranties para manter os remédios próprios do regime daquelas, mormente a possibilidade de desfazimento do contrato e de pedir indenização com base em critério alternativo, que possivelmente proporcione maiores indenizações. ${ }^{171}$

Em curtas palavras, o binômio representations e warranties passou a ser utilizado nos contratos norte-americanos para assegurar ao comprador a proteção de ambos os institutos. Mas isto não impede que as próprias partes regulem em contrato as consequências da violação de declarações e garantias - como sói ocorrer em alienações de participação societária.

Atualmente, a expressão "representations and warranties" tornou-se uma díade que sintetiza e expressa um sistema unitário de declarações, já que normalmente a elas estão atreladas as mesmas consequências jurídicas. ${ }^{172}$ Contratos modernos envolvendo alienação

\footnotetext{
${ }^{169}$ WEST, Glenn D.; SHAH, Kim M. Debunking the myth of the sandbagging buyer: when sellers ask buyers to agree to anti-sandbagging clauses, who is sandbagging whom? The M\&A lawyer, vol.11, n. 1, 2007, p. 4. 170 STARK, Tina L. Drafting contracts: how and why lawyers do what they do. Nova Iorque: Aspen Publishers, 2007, p. 16

${ }^{171}$ DAWSON, Frank Griffith; STYLLIS, Stella. Beyond the pitfalls of bad contract drafting practices: a selection of cross-border legal and cultural misunderstandings. Business Law Review, 2007, n. 28, p. 27

172 HARRISON, Christopher S. Make the deal: negotiating mergers and acquisitions. Nova Jérsei: Bloomberg Press, 2016; PISTORELLI, Roberto. Le garanzie "analitiche" sulle voci della situazione patrimoniale di riferimento. in: Acquisizioni di società e di pacchetti azionari di riferimento, a cura di BONELLI, Franco e DE ANDRÈ, Mauro (orgs.) Milão: Giuffrè, 1990, p. 159.
} 
de participação societária, em sua grande parte, atrelam violações de representations and warranties às consequências jurídicas exclusivamente previstas no próprio contrato, normalmente uma cláusula de indemnity. ${ }^{173}$ Mas a prática se enraizou e até hoje é comum contratos brasileiros reproduzirem os hábitos da praxe norte-americana. Na Inglaterra, para evitar a imiscuição no contrato de conceitos de responsabilidade extracontratual, muitos contratos utilizam apenas a expressão warranties. ${ }^{174}$

Partindo da premissa de que o desfazimento do negócio é uma consequência jurídica indesejada em contratos de aquisição de empresas ou de participação societária, Claude Serfilippi coloca a questão de saber por que os advogados americanos normalmente utilizam a expressão representations and warranties, quando na verdade desejam apenas o remédio da warranty, que é a indenização, tal como fazem os advogados ingleses. O autor identifica que a gama de remédios disponíveis por violação a essas declarações depende menos do rótulo que as partes atribuem à cláusula, do que da capacidade da parte de provar os elementos da misrepresentation. Ou seja, tanto no direito americano quanto no direito inglês, a parte pode ter sucesso em uma ação de misrepresentation se comprovar os seus requisitos, ainda que se trate de uma cláusula de meras warranties - viu-se acima que mesmo no direito inglês a warranty pode subsistir como representation (Introdução supra, n. 4.4.2). A conclusão do autor é que a gama de remédios disponíveis ao adquirente depende mais da dicção da cláusula que exclui outras consequências jurídicas e atribui apenas eficácia indenizatória às warranties ou às representations and warranties, do que propriamente do título da cláusula na qual são feitas as declarações. ${ }^{175}$

\footnotetext{
${ }^{173}$ WEST, Glenn D.; SHAH, Kim M. Debunking the myth of the sandbagging buyer: when sellers ask buyers to agree to anti-sandbagging clauses, who is sandbagging whom? The M\&A lawyer, vol.11, n. 1, 2007, p. 5; WEST, Glenn D.; DURAN, Sarah G. Reassessing the "consequences" of consequential damage waivers in acquisition agreements. The business lawyer, vol. 63, mai./o-2008, p. 786. No caso em que as consequências da violação de uma representation se definam por uma cláusula de indemnity, Luca Renna chega a equiparar o seu conteúdo ao de uma warranty (RENNA, Luca. Compravendita di partecipazioni sociali. Dalla lettera di intenti al closing. Bologna: Zanichelli, 2015, p. 181-182). A opinião não nos parece convincente, pois os efeitos de uma indemnity são bastante diferentes da violação de uma warranty, como se viu acima (Introdução supra, n. 4.2 e 4.3).

${ }^{174}$ FERERA, Leon N.; PHILIPS, John R.; RUNNICLES, John; SCHWARTZ, Jeffery D. Some differences in law and practice between U.K. and U.S. stock purchase agreements. Disponível em: http://www.mondaq.com/uk/x/47706/Contract+Law/Some+Differences+In+Law+And+Practice+Between+U $\mathrm{K}+$ And+US+Stock+Purchase+Agreements. Acesso em 10.2.2018; WEST, Glenn D.; SHAH, Kim M. Debunking the myth of the sandbagging buyer: when sellers ask buyers to agree to anti-sandbagging clauses, who is sandbagging whom? in: The M\&A lawyer, vol.11, n. 1, 2007, p. 4-5; SERFILIPPI, Claude S. A New York lawyer in London: representations and warranties in acquisition agreements - what's the big deal? Artigo publicado no site $\quad$ Lexology, $\quad$ disponível https://www.lexology.com/library/detail.aspx?g=1d954834-a35d-4470-bfa2-bfee233afe41. Acesso em 23 de maio de 2018.

175 SERFILIPPI, Claude S. A New York lawyer in London: representations and warranties in acquisition
} 
A indiferença do título da cláusula para a determinação das consequências jurídicas aplicáveis pode ser vista nos precedentes judiciais norte-americanos. No caso Edwin Bender \& Sons v. Ericson Livestock, ${ }^{176}$ o comissário vendedor de um conjunto de novilhas havia dado uma warranty em nome do vendedor de que a novilhas não estavam prenhas. Quando da descoberta da falsidade da warranty, o comprador ajuizou ação por misrepresentation contra o comissário, o qual contestou que não se tratava de representation, mas de warranty dada diretamente pelo vendedor. $\mathrm{O}$ tribunal de apelação de Nebraska, porém, julgou que mesmo na presença de uma cláusula de warranty é possível que a afirmação seja tratada como representation, se induzir a confiança da parte para celebrar o negócio. O mesmo princípio foi afirmado no caso Newman v. Kendall, ${ }^{177}$ onde o permutante de uma área de terras foi induzido a celebrar o contrato porque tinha sido afirmado no contrato que a área possuía em torno de 100 acres de terra cobertos de madeira virgem, quando na verdade a área havia sido serrada 18 anos antes e havia menos de 100 acres nas condições declaradas no contrato. O comprador ajuizou uma ação por misrepresentation, ao que sobreveio a defesa de que a declaração era uma warranty e não uma representation. Mas a corte de Vermont julgou que tanto uma warranty quanto uma representation podem ser derviadas da mesma afirmação de fato. ${ }^{178}$

Em suma, apesar da diversidade de regimes, não se diferenciam as consequências jurídicas aplicáveis ao par representations and warranties pelo fato de serem afirmações de fatos presentes e passados (representations) ou promessas futuras (warranties), pois da mesma declaração podem ser extraídos os remédios de um ou outro instituto. O regime jurídico depende muito mais do que as partes regulam na cláusula de indemnification.

agreements - what's the big deal? Artigo publicado no site Lexology, disponível em https://www.lexology.com/library/detail.aspx?g=1d954834-a35d-4470-bfa2-bfee233afe41. Acesso em 23 de maio de 2018. Embora o autor em diversas ocasiões restrinja sua análise ao direito do estado de Nova Iorque, parecem-nos aplicáveis suas conclusões à prática americana em geral. A mesma opinião é exarada também por ADAMS, Kenneth A. A lesson in drafting contracts: what's up with 'representations and warranties'? Business Law Today, vol. 15, n. 2, nov./dec. 2015, p. 1-2, no sentido de que os remédios à disposição da parte independem do título da cláusula de declarações. $\mathrm{O}$ autor acrescenta que, se fosse necessário escolher uma única palavra para descrever o conteúdo da cláusula, o melhor seria seguir com o verbete representation, já que a gama mais vasta de remédios é oferecida por este instituto.

${ }^{176}$ Edwin Bender \& Sons v. Ericson Livestock Commission Co., 421 N.W.2d 766 (Neb. 1988).

177 Newman v. Kendall 103 Vt 421 (Vt. 1931).

178 Boa parte da discussão no direito americano gira em torno de saber se as cláusulas de entendimento integral, ou seja, aquelas em que as partes declaram que o contrato escrito reflete todo o acordo havido entre elas, com exclusão de quaisquer outros entendimentos orais havidos na fase pré-contratual, têm o condão de excluir a ação por misrepresentation. A solução diverge de estado para estado, para o que recomendamos a leitura do estudo feito por CUMMING, Elizabeth. Balancing the buyer's right to recover for precontractual misstatements and the seller's ability to disclaim express warranties. Minnesota Law Review, vol. 76, mai./1992 p. 1201-1206. 
As declarações e garantias mais relevantes são fornecidas pelo alienante das ações ou quotas. Mas o adquirente também as pode fornecer, embora normalmente isso ocorra em extensão mais limitada. Em uma ponta da escala, se a contraprestação do adquirente consiste tão somente em dinheiro entregue no ato de assinatura do contrato, o alienante provavelmente não terá interesse em declarações e garantias do adquirente, circunscrevendo-se seu interesse ao recebimento da quantia. À medida, porém, que aumenta a distância no tempo entre assinatura do contrato e pagamento do preço, ou a contraprestação do adquirente move-se da simples quantia em dinheiro para outras formas de contraprestação, como fatias em outras sociedades ou dívidas de earn-out dependentes da performance do adquirente pós-aquisição, o alienante passa a assemelhar-se também ele a um adquirente. Essa passagem normalmente leva à redução de discrepâncias entre as declarações e garantias das partes, e as declarações do adquirente assumem maior relevância. ${ }^{179}$

Já por um ponto de vista comercial, as declarações e garantias auxiliam o adquirente a entender o business da sociedade-alvo, e inclusive para fins de condução da due diligence, permitem ao adquirente recusar-se a fechar a operação se as declarações e garantias forem falsas e outorgarem ao adquirente proteção contratual contra a falsidade das declarações, normalmente na forma de indenização. ${ }^{180}$

\section{Exposição do problema}

A análise empreendida até aqui nos permite concluir que a cláusula de representations and warranties no common law visa equilibrar duas ordens distintas de interesses entre as partes de uma alienação de participação societária. De um lado, visa impor responsabilidade ao alienante da participação por vicissitudes da sociedade-alvo que possam afetar a relação de equivalência entre o valor oferecido pelas ações ou quotas e o seu valor real. Por outro lado, visa oferecer uma via de acesso rápida e eficaz para o adquirente da participação obter ressarcimento pelas perdas sofridas, afastando requisitos

179 AMERICAN BAR ASSOCIATION, Business Law Section. Model stock purchase agreement with commentary. Vol. I. $2^{\text {a }}$ ed. Chicago: ABA Book Publishing, 2010, p. 191; GILSON, Ronald J. Value creation by business lawyers: legal skills and asset pricing. Yale Law Journal, vol. 94, 1984, p. 259, nota de rodapé n. 52; GOLDBERG, Victor P. Protecting reliance. Columbia Law Review, vol. 114, n. 4, mai./2014, p. 1075.

${ }^{180}$ KLING, Lou R.; NUGENT, Eileen T. Negotiated acquisitions of companies, subsidiaries, and divisions. Nova Iorque: Law Jounral Press, 1992, cap. §11.01, p. 11-6 a 11-8. Veja-se também CHU, Wilson. Avoiding surprises through due diligence. Business law today, Vol. 6, No. 3 (jan./fev. 1997), p. 11. 
que de outra forma seriam necessários no regime da misrepresentation, como a confiança e a relevância da declaração falsa.

Vimos que, no common law inglês, as partes possuem incentivos para calibrar a primeira ordem de interesses através de longas cláusulas contratuais de conditions ou warranties, já que, entre outras razões, tem força o princípio caveat emptor e a parol evidence rule. Se o comprador não proteger-se contratualmente, provavelmente ficará sem remédio algum contra vicissitudes negativas da sociedade-alvo. Daí a inserção de cláusulas que lhe garantem a resolução contratual ou ao menos indenização, de acordo com o que for negociado. Nos Estados Unidos, embora o princípio da boa-fé tenha amplitude maior, um comprador cauteloso também tentará proteger-se por meio de estipulações contratuais pelas mesmas razões.

Quanto à segunda ordem de interesses, em ambos os países a franca utilização da cláusula de declarações e garantias se impôs para contornar o tortuoso caminho da ação por misrepresentation, especialmente as dificuldades de prova de confiança do enganado na declaração falsa. Tanto no common law quanto no sistema romano-germânico, a prestação de informação falsa que induz à celebração do contrato possui remédios previstos na lei: lá tutela-se pelo regime da misrepresentation; aqui pelo regime dos vícios de vontade e da responsabilidade pré-contratual.

No common law, tais inconvenientes são contornados através da formalização em contrato das declarações prestadas pelo alienante. Essa estipulação assume a forma de cláusulas tipicamente conhecidas do jurista anglo-saxão: representations, warranties, conditions e indemnities. Ou seja, na prática do common law optou-se por contornar tais problemas usando o arsenal de que dispunha a cultura jurídica daqueles países: através de afirmações fáticas sobre a sociedade-alvo e sobre a participação societária. Isso se explica porque, inicialmente, os advogados americanos buscavam proteger seus clientes por meio do instituto da misrepresentation, que exige no common law a prestação de afirmações de fato falsas pela parte (como visto, o silêncio normalmente não configura misrepresentation). A partir daí buscou-se fazer uma passagem da misrepresentation para os institutos da warranty, das conditions e das indemnities.

Tais fórmulas são, porém, estranhas ao jurista brasileiro. A responsabilidade por indução a erro, por sinal, sequer necessita que afirmações positivas fáticas sejam prestadas no direito nacional, sendo pacificamente aceitas as figuras do dolo por omissão (CC, art. 
147), do erro cognoscível (CC, art. 138) e da responsabilidade pré-contratual por falha no dever de informar. É preciso, assim, analisar quais as funções exercidas pelas declarações e garantias no direito brasileiro e como se relacionam com os institutos próprios à nossa cultura jurídica.

Podemos assim colocar a problemática da natureza jurídica da cláusula de declarações e garantias no direito brasileiro como o formato jurídico pelo qual uma parte assume responsabilidade contratual para proteger a outra parte contra vicissitudes da sociedade-alvo que de outra forma ficariam sem proteção nenhuma ou encontrariam proteção apenas nos estreitos limites dos vícios de vontade e da responsabilidade précontratual. $\mathrm{Ou}$, no dizer de dois autores americanos, estamos diante da arte de contratar para evitar responsabilidade extracontratual. ${ }^{181} \mathrm{~A}$ transformação das pretensões das partes em contrato, na verdade, é a própria essência da cláusula de declarações e garantias. ${ }^{182}$

Nossa tarefa será, portanto, identificar as formas pelas quais as partes podem, no direito brasileiro, transformar em contrato a responsabilidade por afirmações fáticas sobre a sociedade-alvo ou sobre as ações ou quotas, ou se é possível uma cláusula contratual influir no regime de responsabilidade previsto em lei para as hipóteses mencionadas supra. É o que passamos agora a fazer.

${ }^{181}$ Como sugestivamente indica o título do artigo de Glenn D. West e Benton W. Lewis Jr., Contracting to avoid extra-contractual liability - can your contractual deal ever really be the "entire" deal? The business lawyer, vol. 64 (agosto-2009), p. 999-1038.

${ }^{182}$ BAINBRIDGE, Stephen M. Mergers and acquisitions. $3^{\mathrm{a}}$ ed. Nova Iorque: Foundation Press, 2012, p. 80. 


\section{CONCLUSÃO}

Notamos no capítulo introdutório deste trabalho que a cláusula de declarações e garantias tem origem no sistema de common law. Lá, onde as obras contratuais costumam ser longas e detalhistas, surgiram as declarações e garantias para reunir a proteção do regime da misrepresentation e da warranty. A misrepresentation confere tutela extracontratual à parte que foi induzida a celebrar o contrato por afirmações de fato falsas da outra parte, mas em regra não se a parte silenciou sobre uma informação relevante. Preenchidos os requisitos da misrepresentation, a parte prejudicada pode pedir desfazimento do negócio e indenização pelos out-of pocket expenses. Já a warranty confere proteção contratual por determinadas afirmações de fato feitas sobre o bem objeto do negócio, oferecendo em regra tutela indenizatória segundo o critério benefit of the bargain.

A cláusula de declarações e garantias surge, assim, para obviar o inconveniente da prática contratual antiga de incluir uma cláusula de representations, onde a parte prejudicada tinha de provar que confiou na misrepresentation para celebrar o negócio. Com uma warranty, basta provar o descumprimento do contrato para pedir indenização. Compreende-se que o desenvolvimento da cláusula de declarações e garantias deve-se muito aos esquemas de responsabilidade conhecidos dos advogados do common law, notadamente à formatação da responsabilidade por misrepresentation e por breach of warranty. Hoje em dia, é mais comum as partes exluírem todos os demais remédios jurídicos disponíveis e pactuarem apenas o ressarcimento de certas perdas definidas em contrato. Muda-se assim o esquema clássico das representations e das warranties em direção ao instituto das indemnities.

No direito brasileiro, tal formatação é de difícil apreensão, pois não há aqui um instituto voltado apenas a tutelar a parte contra afirmações inexatas da contraparte, sejam elas dolosas, negligentes ou inocentes. É preciso compreender, portanto, a função da cláusula de declarações e garantias para identificar sua natureza jurídica no direito brasileiro.

A cláusula de declarações e garantias constitui um tipo contratual (de cláusula contratual), embora não seja um tipo legal. Quando utilizada em alienação de participação societária, desempenha uma função socialmente típica de garantia, embora possa exercer também funções conformativa, informativa e probatória. A exata medida das declarações e 
garantias no caso concreto dependerá de uma análise que envolve vários índices de tipo, tais como seu objeto, seu fim, seu horizonte de sentido, sua configuração.

A função concretamente exercida pela cláusula de declarações e garantias é que determinará sua natureza jurídica. Ao longo deste trabalho demonstrou-se que as declarações e garantias podem assumir duas naturezas jurídicas distintas com base no contrato, além de poderem relacionar-se com outros quatro regimes jurídicos previstos em lei, de forma concorrente. Não há concorrência entre as duas possíveis naturezas jurídicas contratuais: ou é obrigação de garantia, ou é especificação da obrigação de dar. Ou é um, ou é outro. Mas pode haver concorrência de regimes entre as naturezas jurídicas contratuais e os institutos disciplinados em lei, conforme esquema abaixo:

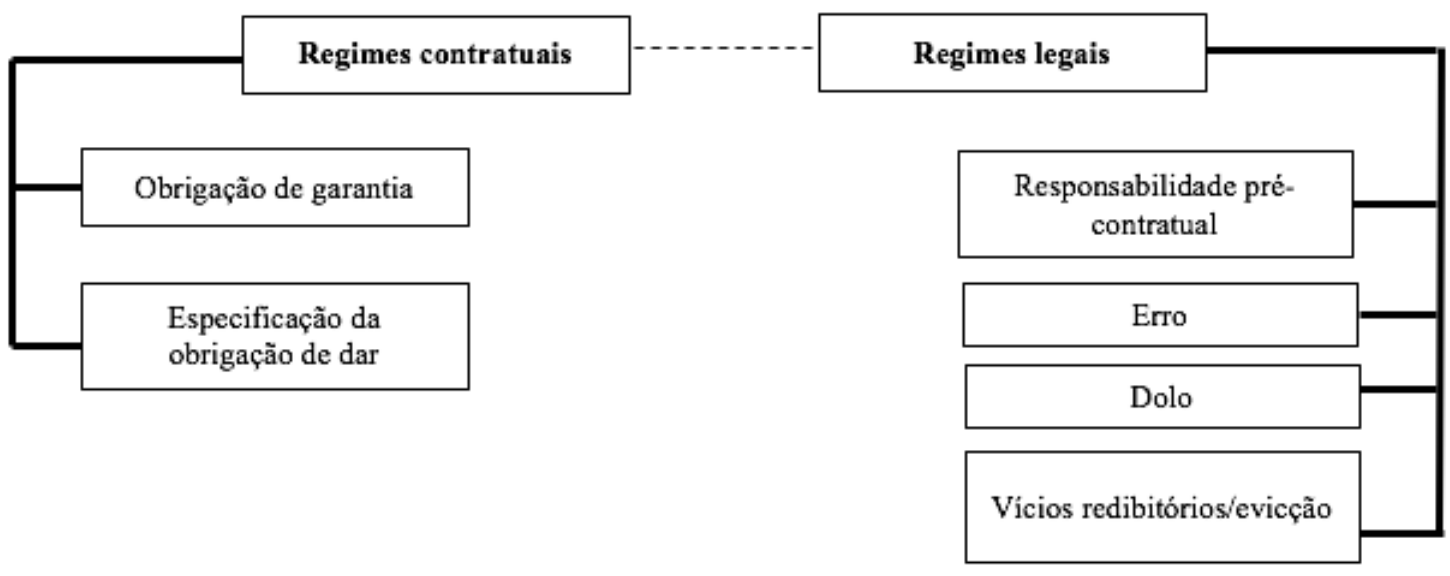

$\mathrm{Na}$ ausência de declarações e garantias, os itens que compõem o patrimônio social ou os caracteres da atividade social configuram meros motivos do negócio e são, portanto, irrelevantes. Não poderia ser diferente, pois o objeto do negócio é a participação societária e não os bens sociais. Qualquer tutela deve ser dirigida apenas à própria participação societária. Ou seja, apenas o erro quanto a características da própria participação, ou vícios redibitórios e evicção incidentes sobre as ações ou quotas são dignos de tutela.

Na presença de cláusula de declarações e garantias, a situação muda.

Como obrigação de garantia, as declarações e garantias transferem ao declarante o risco de concretização de determinado evento adverso ao co-contratante. A ocorrência do risco não configura inadimplemento contratual pelo declarante, vez que este não se obrigou a impedir a ocorrência do risco. Mas o risco é pressuposto para o surgimento de uma obrigação ulterior, que pode ser livremente estipulada pelas partes. Normalmente esta 
obrigação será o pagamento de uma soma garantida, a redução do preço de compra, o desfazimento do negócio ou a sanação do risco in natura. Índice de tipo fortíssimo de que as partes pactuaram uma obrigação de garantia é a estipulação de um prazo de garantia dentro do qual, e apenas dentro do qual, o declarante assume responsabilidade pela concretização dos riscos determinados na cláusula de declarações e garantias.

Já em sua função conformativa, as declarações e garantias se qualificam como especificação da obrigação de dar a participação societária dotada de certas qualidades. As características da atividade da sociedade e do patrimônio social deixam o campo dos simples motivos e passam, por ação da vontade das partes, a ser uma qualidade prometida da própria participação societária. Aqui sim haverá verdadeiro inadimplemento se as ações ou quotas não apresentarem as qualidades prometidas pelo declarante. A consequência será a possibilidade de pedir cumprimento específico, indenização e, eventualmente, resolução contratual por inadimplemento.

Passando aos regimes legais, é preciso antes de mais nada salientar que eles podem aplicar-se independentemente de cláusula de declarações e garantias, pois decorrem diretamente da própria lei. Contudo, a concretização de tais institutos pode ser facilitada pela presença de declarações e garantias, atuando aqui em suas funções informativa e probatória.

A responsabilidade pré-contratual por falha ao dever de informar pode ter sua comprovação facilitada pelas declarações e garantias, mas não surge por força delas. $\mathrm{O}$ dever de informar surge na fase pré-contratual quanto a qualquer informação capaz de alterar o comportamento da outra parte no momento de celebrar o negócio. A amplitude e a intensidade de tal dever variam sensivelmente de caso a caso. Como a participação societária é objeto demasiado complexo, a exata medida do dever de informar é dada no caso concreto pela interação entre credor e devedor da informação: aquele mostrando a este quais as informações que julga necessárias para formar seu convencimento quanto à conveniência do negócio; este fornecendo as informações solicitadas e outras mais que, embora não tenham sido solicitadas, se afigurem como relevantes ao negócio. A violação ao dever de informar, no entanto, raramente oferecerá tutela adequada, pois não permite o desfazimento do negócio, mas apenas tutela indenizatória pelo interesse negativo. Em alienação de participação societária, o interesse negativo reflete-se no valor que o adquirente teria pago a menor pela participação se tivesse a informação adequada, mas será 
complicado comprovar que o alienante teria aceito preço menor, além das naturais dificuldades com a reavaliação da sociedade.

O erro não deve incidir, em regra, sobre defeitos ou inconsistências do patrimônio social ou das atividades sociais, pois estes não configuram qualidade essencial do objeto do negócio (que é a participação societária). As declarações e garantias, porém, podem atuar indicando o que as partes consideram qualidade essencial do objeto do negócio, fazendo com que as características da sociedade que eram simples motivos possam gerar invalidade do negócio por erro. Além disso, as declarações e garantias fazem presumir a escusabilidade do erro e a sua cognoscibilidade pelo declarante, que ficará virtualmente impedido de alegar que não pôde perceber o erro da contraparte.

O dolo pode incidir sobre os motivos. Portanto, mesmo na completa ausência de declarações e garantias, pode o deceptus pedir anulação do negócio por indução a erro sobre as características da sociedade-alvo. Será difícil ao deceptus comprovar a conduta maliciosa da contraparte, o intento de enganar e o caráter essencial do dolo, mas se preenchidos os requisitos, o engano sobre os meros motivos não será óbice. A jurisprudência nacional tem adicionado ainda o requisito de escusabilidade ao dolo em sede de alienação de participação societária, exigindo que o adquirente tome as precauções devidas para investigar a real situação da sociedade antes de realizar o negócio. Neste quadro, as declarações e garantias não são imprescindíveis, mas auxiliam o julgador a identificar a existência de conduta maliciosa.

Os vícios redibitórios apenas conferem tutela ao adquirente da participação societária quando incidirem diretamente sobre a própria participação societária. Este será o caso quando os defeitos sobre os bens ou sobre as atividades sociais forem de tamanha gravidade a ponto de minar a função ou valor da própria participação societária. A cláusula de declarações e garantias em nada auxiliará na concretização do vício redibitório, pois aí atuará ou como promessa de qualidades ou como assunção de garantia. Será impossível comunicar-se ao regime de vícios do objeto, vez que este protege o preenchimento das qualidades normais da coisa, ao passo que a especificação de qualidades protege quanto às qualidades convencionais da coisa.

Por fim, a evicção pode incidir diretamente sobre a participação societária, mas vale aqui também a regra de que a evicção sobre os bens sociais não gera vício da participação societária senão quando for extremamente grave. A cláusula de declarações e garantias 
poderá, embora apenas raramente aconteça, repetir o regime de evicção sobre as ações ou quotas, modificando-o ou reforçando-o.

Em síntese, uma aplicação sisteticamente consciente da cláusula de declarações e garantias abre um leque de oportunidades ao operador do direito brasileiro. O propósito deste trabalho foi identificar de que forma as declarações e garantias se relacionam com os requisitos de cada um desses regimes. 


\section{ANEXO \\ Modelo de cláusulas de declarações e garantias}

Modelo extraído do Contrato de Compra e Venda de Quotas e Outras Avenças extraído dos autos do processo n. 1066058-37.2015.8.26.0100 (18 ${ }^{\mathrm{a}}$ Vara Cível do Foro Central de São Paulo/SP):

3.7. Declarações dos VENDEDORES. OS VENDEDORES, em caráter solidário, declaram e garantem aos COMPRADORES que as seguintes deciarações e garantias são verdadeiras, precisas, completas e válidas:

3.7.1. Organização. A INTEGRAL é sociedade devidamente constituída e validamente existente nos termos das leis da República Federativa do Brasil. A INTEGRAL tem plena capacidade, legitimidade e está legalmente habilitada a conduzir as suas atividades e os seus Negócios, conforme o caso, como atualmente conduzidos, bem como a deter e utilizar todos os seus bens e ativos, incluindo os ativos do Negócio. Os atos constitutivos da INTEGRAL são válidos e vinculam seus sócios e administradores.

3.7.2. Capacidade, Legitimidade e Autorização. Cada um dos VENDEDORES e a INTEGRAL têm poder e autoridade necessários para celebrar e executar este Contrato, os documentos necessários à implementação da Operação e para cumprir as obrigações contidas neste Contrato e nos documentos da Operação. Cada um dos VENDEDORES, a INTEGRAL e seus representantes legais têm plena capacidade civil e legitimidade, estão devidamente autorizados a celebrar este Contrato e os outros documentos da Operação e para cumprir as obrigações contidas neste Contrato, não havendo nenhuma obstrução legal, contratual, obrigacional, judicial e/ou restrição de qualquer natureza que impeça a assinatura e execução deste Contrato e dos demais documentos da Operação e a conclusão da compra e venda de Quotas por cada um dos VENDEDORES e pela INTEGRAL. Nenhuma outra providência ou medida è necessária para autorizar a celebração, implementação e cumprimento deste Contrato pelos VENDEDORES e pela INTEGRAL, exceto conforme disposto neste Contrato

3.73. Efeito Vinculante. Este Contrato foi assinado por cada um dos VENDEDORES, peloS COMPRADORES E pela INTEGRAL e constitui uma obrigação válida, vinculante e exequivel para cada um dos VENDEDORES, seus sucessoresie herdeiros, para cada um dos COMPRADORES, seus sucessores e herdeiros, e para a INTEGRAL. Cada um dos documentos necessários para a implementaçăo da Operação constitui ou constituirá uma obrigação válida e exequível de acordo com seus respectivos termos. 
3.7.4. Ausência de Conflitos e Consentimentos. A assinatura e a execução deste Contrato por cada um dos VENDEDORES e pela INTEGRAL, bem como a assinatura por eles dos demais documentos da Operação não:

(i) violam, contradizem ou implicam a violação de qualquer documento constitutivo das Sociedades. ou qualquer deliberação societária de seus respectivos sócios;

(ii) violam ou contradizem: qualquer lei, regulamento ou ordem aplicável a qualquer um dos VENDEDORES, à INTEGRAL ou aos seus respectivos ativos ou bens;

(iii) violám ou contradizem quaiçuer decisão ou julgado emitido por qualquer Autoridade Governamental, apilicável a qualquer um dos VENDEDORES, à INTEGRAL ou aos seus respectivos ativos ou bens, em qualquer caso, tanto quanto seja do conhecimento de qualquer um dos VENDEDORES; e

(iv) criam qualquer Ônus șobre qualquer ativo e/ou bem da INTEGRAL ou sobre as Quotas, exceto em relação às obrigações constantes nește Contrato e nos demais documentos da Operação ou dos mesmos derivadas.

3.7.5. Capital Social e Quotas da INTEGRAL. O capital social da INTEGRAL, totalmente subscrito e integralizado, é representado, na presente data, pelos valores e quantidades de Quotas descritas no Anexo 3.7.5. Os VENDEDORES são legítimos proprietários e titulares das Quotas conforme descrito no Anexo 3.7.5, juntamente com tudo o que as mesmas representam, incluindo o direito a dividendos e quaisquer outros direitos relacionados às mesmas. As Quotas estarão, na Data de Fechamento, totalmente livres e desembaraçadas de quaisquer Ônus.

3.7.6. Informacões Relevantes. OS VENDEDORES declaram ter disponibilizado aos COMPRADORES todas e quaisquer informações relevantes da INTEGRAL que tenham ou possam gerar qualquer alteração ou evento significantemente prejudicial aos ativos do Negúcio, às condições financeiras ou resultados das operações da INTEGRAL e/ou do Negócio ("informaçóes Relevantes").

3.7.7. Contingências. Os COMPRADORES declaram estar cientes da situação, patrimonial e contábil da INTEGRAL, que possui passivo de $R \$ 4.029 .928,45$ (quatro milhöes, vinte e nove mil, novecentos e vinte e oito reais e quarenta e cinco centavos), conforme descritivo anexo a este instrumento particular, já decrescido do valor de mercado das cotas, o qual será integralmente assumido pelos COMPRADORES, responsabilizando-se estes, assim, exclusivamente, pela liquidaçăo da totalidade da dívida da INTEGRAL indicadas nesta cláusula e no Arexo 2.2.(a). 
3.7.7.1. OS VENDEDORES declaram que a INTEGRAL não tem demais dividas ou passivos de qualquer natureza, inclusive, mas não se limitando, às de natureza fiscal, trabalhista, ambiental, previdenciária, civil ou comercial, contingentes ou outràs, exceção feità às que estejam indicadas na cláusula supra e no Anexo 2.2.(a) deste Contrato ou refletidas no balanço patrịmonial da INTEGRAL, apresentado nesta dạta aos COMPRADORES, o qual integra o presente Contrato como Anexo 3.7.7.

3.7.7.2. Balanco Patrimonial. O Anexo 3.7.7 contém cópia completa do balanço patrimonia! da INTEGRAL (o "Balanço Patrimonial"), referente ao período encerrado em 30/06/13 e balancete do mês imediatamente anterior ao da Data do Fechamento. O Balanço Patrimonial (i) foi preparado de acordo com os princípios contábeis geralmente aceitos no, Brásil; aplicados de forma consistente em todos os períodos cobertos, e (ii) está compléto, correto e representa fieimente a posição financeira consolidada e os

resultados das operaçóes da :NTEGRAL; bem como reflete precisamente todos os ativos, passivos, dividas e obrigaçōes da INTEGRAL no período a que se refere.

3.7.8. Ativos, Bens e Investimentos. A INTEGRAL detém e é legítima proprietária e possuidora de todos os ativos e bens refletidos no Balanço Patrimonial, os quais foram contabilizados de acordo com as norrnas e principios contábeis vigentes, sendo que tais ativos e bens estāo livres e desembaraçados de todós e quaisquer Ônus. Todos os ativos da INTEGRAL encontram-se em condiçöes normais de operação e têm sido objeto de manutençăo adequada e estão em boas condições de funcionamento e reparo e aptos a continuarem os Negócios do mesmó modo que têm sido conduzidos até esta data. Não há qualquer questionamento ou potencial questionamento por qualquer Autoridade relacionado aos ativos da INTEGRAL. A INTEGRAL não detém qualquer partícipação acionária em qualquer outra sociedade.

3.7.8.1. Eventual participaçăo açionária da INTEGRAL em sociedade que vier a ser constituida para contrataçăo de profissionais de enfermagem denominada, para fins de atendimento a acordo ou Termo de Ajustamento de Conduta - TAC firmado com o Ministério Público, nos termos da Cláusula 3.1.1, item xiii, e desde que tenha sido estabelecido prazo para o cumprimento das obrigaçōes do TAC entre a data de assinatura e a Data do fechamento, deverá contar com a anuência expressa dos COMPRADORES, condicionada ainda à participação dos COMPRADORES como intervenientes em qualquer documento celebrado perante o Ministério Público do Trabalho e/ou outras autoridades competentes para fiscalizaçăo das relações de trabalho e/ou ainda autoridades registrárias. 
3.8. Declaraçóes dos COMPRADORES. Os COMPRADORES, em caráter solidário, declaram e garantem aos VENDEDORES que as seguintes declarações e garantias săo verdadeiras, precisas, completas e válidas:

3.8.1. Capacidade e Legitimidade. Cada um dos COMPRADORES tem poderes para celebrar e executar este Contrato, os documentos necessários à implementação da Operaçäo e para cumprir as obrigações contidas neste Contrato e nos documentos da Operação. Cada um dos COMPRADORES tem plena capacidade civil e legitimidade, estāo devidamente autorizados a celebrar este Contrato e os outros documentos da Operaçăo $\mathrm{e}$ para cumprir as obrigaçōes contidas neste Contrato, não havendo nenhuma obstrução legal, contratual, obrigacional, judicial e/ou restriçäo de qualquer natureza que impeça a assinatura e execução deste Contrato e dos demais documentos da Operação e a conclusão da compra e venda de Quotas por cada um dos COMPRADORES. Nenhuma outra providência ou medida é necessária para autorizar a celebraçăo, implementação e cumprimento deste contrato pelos COMPRADORES, exceto conforme disposto neste contrato.

3.8.2. Os COMPRADORES tem experiência em assuntos médicos, financeiros e societários, de modo que são capazes de avaliar, nos limites das informações fornecidas pelos VENDEDORES, a INTEGRAL e.as obrigações financeiras impostas pelo presente Contrato, nos termos e limites previstos neste Contrato. 


\section{BIBLIOGRAFIA PESQUISADA}

ABLA, Maristela Sabbag. Sucessão empresarial - declarações e garantias - o papel da legal due diligence. in: CASTRO, Rodrigo Monteiro de; ARAGÃO, Leandro Santos de (coords.), Reorganização societária. São Paulo: Quartier Latin, 2005, p. 100-121.

ADAM, Ulrich. Unternehmenskauf, Verkäuferhaftung und Vertragsgestaltung. Frankfurt am Main: Peter Lang, 2004.

ADAMEK, Marcelo Vieira von. Responsabilidade civil dos administradores de S/A e as ações correlatas. São Paulo: Saraiva, 2009.

ADAMS, Kenneth. Revisiting materiality: the ambiguity at the heart of a fundamental contract concept. New York Law Journal, 16.8.2017.

A legal-usage analysis of "material adverse change" provisions. Fordham Journal of Corporate and Financial Law, vol. 10, 2004.

A lesson in drafting contracts: what's up with 'representations and warranties'? Business Law Today, vol. 15, n. 2, nov./dec. 2015.

AGUIAR JÚNIOR, Ruy Rosado. Extinção dos contratos por incumprimento do devedor. $2^{\mathrm{a}}$ ed. Rio de Janeiro: AIDE Editora, 2003.

Comentários ao Novo Código Civil. Vol. VI, tomo II: Da extinção do contrato (arts. 472 a 480). Rio de Janeiro: Forense, 2011.

ALPA, Guido; MARICONDA, Vincenzo. Livro IV. in: ALPA, Guido; MARICONDA, Vincenzo; CUFFARO, Vincenzo (coords.) Codice civile commentato. Milão: IPSOA, 2009.

ALVIM, Pedro. O contrato de seguro. $3^{\text {a }}$ ed. Rio de Janeiro: Forense, 2001.

AMARAL, Francisco. Direito civil: introdução. $5^{\text {a }}$ ed. rev., atual, e aum. de acordo com o novo código civil. Rio de Janeiro: Renovar, 2005.

AMBROSINI, Stefano. Trasferimento di partecipazioni azionarie, clausole de indemnity e contratto per persona da nominare. in: Contratto e impresa, ano 12, n. 3, 1996. 
AMERICAN BAR ASSOCIATION, Business Law Section. Model stock purchase agreement with commentary. Vol. I. $2^{\text {a }}$ ed. Chicago: ABA Book Publishing, 2010.

AMERICAN BAR ASSOCIATION. Report of the ABA business law section task force on delivery of document review reports to third parties. The Business Lawyer, vol. 67, n. 1, nov./2011.

AMERICAN LAW INSTITUTE. Restatement of the Law second contracts $\S 11-177$. Saint Paul: American Law Institute Publisher, 1981.

ANDREOLI, Marcello. La cessione del contratto. Padova: CEDAM, 1951.

ANDREWS, Neil. Contract rules: decoding English Law. Plymouth: Intersentia, 2016.

ANGELI, Guillaume. La garantie du passif dans les cessions de sites industriels. Revue juridique de l'environnement, n. 3, 1996, p. 307.

ASCARELLI, Tullio. Problemas da sociedades anônimas e direito comparado. São Paulo: Saraiva, 1945.

In tema di vendita di azioni e responsabilità degli amministratori. Il foro italiano, vol. 76, n. 11 (1953).

Riflessioni in tema di titoli azionari e società tra società. in: saggi di diritto commerciale. Milão: Giuffrè, 1955.

O empresário. Trad. de Fábio Konder Comparato. Revista de Direito Mercantil, Indsutrial, Econômico e Financeiro, 1998, n. 109, p. 183-189.

ASQUINI, Alberto. Perfis da empresa. Trad. de Fábio Konder Comparato. Revista de Direito Mercantil, Indsutrial, Econômico e Financeiro, 1996, n. 104, p. 109-126.

ASSIS, Araken de. Do Direito das Obrigações (arts. 421 a 578). in: ALVIM, Arruda; ALVIM, Thereza (coords), Comentários ao Código Civil Brasileiro, vol. V. Rio de Janeiro: Forense, 2007.

Resolução do contrato por inadimplemento. $5^{\text {a }}$ ed. rev. e atual. São Paulo: Revista dos Tribunais, 2013 
AVERY, Daniel; WEINTRAUB, Daniel. Trends in M\&A provisions: the "materiality scrape". Bloomberg law reports - mergers and acquisitions, vol. 5, n. 2.

ÁVILA, Humberto Bergmann. Sistema Constitucional Tributário. $2^{\mathrm{a}}$ ed. rev. e atual. São Paulo: Saraiva, 2006.

AZEVEDO, Antônio Junqueira de. Negócio jurídico e declaração negocial (noções gerais e formação de declaração negocial). São Paulo, 1986.

Negócio jurídico: existência, validade e eficácia. $4^{\mathrm{a}}$ ed. atual. de acordo com o novo Código Civil. São Paulo: Saraiva, 2002.

AZEVEDO, Luis Augusto Roux. A comutatividade do contrato de seguro. Dissertação (Mestrado em Direito) - Faculdade de Direito, Universidade de São Paulo, São Paulo, 2010 .

AZEVEDO JÚNIOR, José Osório. Compra e Venda. Troca ou Permuta. in: REALE, Miguel; MARTINS-COSTA, Judith (coords.), estudos em homenagem ao professor Miguel Reale. São Paulo: Revista dos Tribunais, 2005.

BAINBRIDGE, Stephen M. Mergers and acquisitions. $3^{\mathrm{a}}$ ed. Nova Iorque: Foundation Press, 2012.

BALEEIRO, Aliomar. Limitações Constitucionais ao Poder de Tributar. $8^{\mathrm{a}}$ ed. Rio de Janeiro: Editoras Forense, Gen e Billac Pinto, 2010.

BARAD, Edward N. Colorado purchase and sale issues for buyers. The practical real estate lawyer, jul./2017.

BATALHA, Wilson de Souza Campos. Defeitos dos negócios jurídicos. Rio de Janeiro: Forense, 1988.

BDINE JR., Hamid Charaf. Cessão da posição contratual. São Paulo: Saraiva, 2007.

BEINERT, Dieter; BURMEISTER, Frank; TRIES, Hermann-Josef. Mergers and acquisitions in Germany. Munique: Verlag C. H. Beck, 2009.

BEISEL, Wilhelm; KLUMPP, Hans-Hermann; Der Unternehmenskauf. $7^{a}$ ed. Munique: C.H. Beck, 2015. 
BÉNABENT, Alain. Droit des contrats spéciaux civils et commerciaux. $11^{\mathrm{a}}$ ed. Paris: LGDJ, 2015.

Droit civil: les obligations. 6 ${ }^{\text {a }}$ ed. Paris: Montchrestien, 1997.

BENATTI, Francesco. A responsabilidade pré-contratual. Trad. Adriano Vera Jardim e Caeiro. Coimbra: Almedina, 1970.

BENETTI, Giovana Valentiniano. Dolo por omissão no direito civil brasileiro: fundamentos, requisitos e efeitos. Tese (Doutorado em Direito) - Faculdade de Direito, Universidade de São Paulo, São Paulo, 2018.

BERTINO, Lorenzo. Le trattative prenegoziali e i terzi. in: quaderni di responsabilità civile e previdenza, vol. 16. Milão: Giuffrè, 2009.

BETTI, Emilio. Teoria generale delle obbligazioni. Vol. II. Milão: Giuffrè, 1953.

BEUTHIEN, Volker. Zur Mitgliedschaft als Grundbegriff des Gesellschaftsrechts subjektives Recht oder Stellung im pflichthaltigen Rechtsverhältnis? in: WANK, Rolf et al. (orgs.) Festschrift für Herbert Wiedemann zum 70. Geburtstag. Munique: Verlag C.H. Beck, 2002.

BEVILAQUA, Clovis. Código civil dos Estados Unidos do Brasil. Vol. IV. $6^{\mathrm{a}}$ ed. Rio de Janeiro: Livraria Francisco Alves, 1943.

BIANCA, Massimo. La vendita e la permuta. in: Filippo Vassalli (org.) Tratatto di diritto civile italiano. Volume settimo. Tomo primo. Turim: UTET, 1993.

BISLE, Michael. Gewährleistungs- und Garantieklauseln in Unternehmenskaufverträgen. Deutsches Steuerrecht, 2013.

BLACK, Henry Campbell. Black's Law dictionary. $5^{\text {a }}$ ed. Saint Paul: West Publishing, 1979.

BONELLI, Franco. Giurisprudenza e dottrina su acquisizioni di società e di pacchetti azionari di riferimento. in: Acquisizioni di società e di pacchetti azionari di riferimento, a cura di BONELLI, Franco e DE ANDRÈ, Mauro (orgs.) Milão: Giuffrè, 1990.

Acquisizioni di società e di pacchetti azionari di riferimento: le garanzie del venditore. Diritto del Commmercio Internazionale, 2007, vol. 21.2, p. 293-324. 
BORDEN, Michael J. Mistake and disclosure in a model of two-sided informational inputs. Cleveland State University, Research Paper 08-156, abril de 2008.

BORGES, João Eunápio. Curso de direito comercial terrestre. $5^{\text {a }}$ ed. Rio de Janeiro: Forense, 1976.

BREUER, Matthias. Mängelhaftung beim Unternehmens- und Beteiligungskauf nach dem Schuldrechtsmodernisierungsgesetz. Berlim: Logos Verlag, 2006.

BRIDGE, Michael J. The sale of goods. $3^{\text {a }}$ ed. Oxford: Oxford University Press, 2014.

BROWN, Robert L. The concise guide to mergers, acquisitions and divestitures. Nova Iorque: Palgrave Macmillan, 2007.

BROX, Hans; WALKER; Wolf-Dietrich. Allgemeiner Teil des BGB. 35 ed. Munique: Verlag Franz Vahlen, 2011.

- Besonderes Schuldrecht. $28^{\mathrm{a}}$ ed. Munique: Verlag Franz

Vahlen, 2001.

BUFULIN, Augusto Passamani. O erro e seus requisitos. Rio de Janeiro: Editora GZ, 2013.

BUSCHINELLI, Gabriel Saad Kik. Compra e venda de participações societárias de controle. Tese (Doutorado em Direito) - Faculdade de Direito, Universidade de São Paulo, São Paulo, 2017.

BUSSIAN, Wolf Rainer. Due Diligence bei Pakettranksationen. Frankfurt am Main (et al.): Peter Lang, 2008.

BUTTARO, Luca. L’interesse nell'assicurazione. Milão: Giuffrè, 1954.

CAFFIN-MOI, Marie. Cession de droits sociaux et droit des contrats. Paris: Ed. Economica, 2009.

; BECKER, Bernard-Olivier; BUCHBERGER, Matthieu. Cessions de droits sociaux. La Semaine Juridique Entreprise et Affaires, n. 39, 2013, p. 1519.

CALERA, Maria del Carmen Gete-Alonso y. Estructura y función del tipo contractual. Barcelona: Bosch, 1979. 
CALNAN, Richard. Principles of contractual interpretation. Oxford: Oxford University Press, 2013.

CANARIS, Claus-Wilhelm. Leistungsstörungen beim Unternehmenskauf. Zeitschrift für Unternehmens- und Gesellschaftsrecht 3.

. Leistungsstörungen und Gewährleistung beim Unternehmenskauf nach der Reform des deutschen Shchuldrechts. in: STATHOPOULOS, Michael; BEYS, Kostas; DORIS, Philippos; KARAKOSTAS, Ioannis (orgs.), Festschrift für Apostolos Georgiades zum 70. Geburtstag. Munique: C. H. Beck, 2006, p. 71-94.

CARBONNIER, Jean. Droi civil. vol. 4: les obligations. Paris: Presses universitaires de France, 1982.

CARRILLO, Pablo Enrique. Beware of Scylla and Charybdis: stock purchase of privately held companies and the remedies problem under Rule 10b-5 - what is buyer to do? Tulane Law Review, vol. 72, jun./1998.

CARTWRIGHT, John. Contract Law: an introduction to the English Law of contract for the civil lawyer. $3^{\text {a }}$ ed. Oxford, Portland: Bloomsbury, 2016.

CARVALHO SANTOS, Jorge M. de. Código civil brasileiro interpretado. Vol. II. $9^{\mathrm{a}}$ ed. Rio de Janeiro: Freitas Bastos, 1964.

CARVALHO SANTOS, Jorge M. de. Código civil brasileiro interpretado. Vol. XVI. $2^{\mathrm{a}}$ ed. Rio de Janeiro: Freitas Bastos, 1938.

CARVAlHOSA, Modesto. Parte especial. Do direito de empresa. $2^{\mathrm{a}}$ ed. in: Antônio Junqueira de Azevedo (coord.), comentários ao código civil. Vol. 13. São Paulo: Saraiva, 2005.

Comentários à lei de sociedades anônimas. $1^{\mathrm{o}}$ vol. arts 1 a $74.4^{\mathrm{a}}$ ed. São Paulo: Saraiva, 2002.

Comentários à lei de sociedades anônimas. $2^{\circ}$ vol. arts. 75 a 137. $4^{\mathrm{a}}$ ed. São

Paulo: Saraiva, 2009 
CASELLA, Paolo. I due sostanziali metodi di garanzia al compratore. in: Acquisizioni di società e di pacchetti azionari di riferimento, a cura di BONELLI, Franco e DE ANDRÈ, Mauro (orgs.) Milão: Giuffrè, 1990.

CASSOTTANA, Marco. Rappresentazioni e garanzie nei conferimenti d'azienda in società per azioni. Milão: Giuffrè, 2006.

CESAR, Dimas de Oliveira. Estudo sobre a cessão do contrato. São Paulo: Revista dos Tribunais, 1954.

CHAMPAUD, Claude. Cession de parts sociales ou d'actions. Garantie du cédant, Action en annulation (Paris, 3 Ch. A. , 4 févr. 1992, Sté UMHS c/ Souchon ès qual.). Revue trimestrielle de droit commercial et de droit économique, n. 4, out./dez. 1992, p. 822-826.

; DANET, Didier. Annulation d'une cession d'actions pour erreur sur les qualités substantielles du contrat (Com. 1er oct. 1991, SNC Quille c/ Gilbert et autres, Bull. Joly 1991. 1004, § 352; Paris 11 sept. 1990, Bloem c/ SCI Yoko Erdian, D. 1991. Somm. com. 161, note Tournafond). Revue trimestrielle de droit commercial et de droit économique, n. 1, jan./mar. 1992, p. 199-201.

Annulation d'une cession d'actions pour dol (Paris, 25 ch. B, 12 juill. 1991, Villar c/ Rondeau, Bull. Joly 1991. 922, §327, note Couret; Lyon, 3 ch., 29 mars 1991, inédit, Gouchon c/ Roux, Lerant et autres). Revue trimestrielle de droit commercial et de droit économique, n. 1, jan./mar. 1992, p. 201.

Cession de parts sociales ou d'action. Réticence dolosive, cause de la cession (Paris 25 ch. B, 12 juill. 1991, Villard c/ Rondeau). Revue trimestrielle de droit commercial et de droit économique, n. 3, jul./set. 1992, p. 622-625.

CHAVES, Antônio. Responsabilidade pré-contratual. $2^{\mathrm{a}}$ ed. rev. ampl. e atual. Guarulhos: Editora Parma .

CHIRELSTEIN, Marvin A. Concepts and case analysis in the law of contracts. $2^{\mathrm{a}}$ ed. Saint Paul: Foundation Press, 2013.

CHITTY, Joseph Junior. Chitty on contracts. Vol. 1: general principles. 32a ed. Londres: Thomson Reuter, 2015. 
CHU, Wilson. Avoiding surprises through due diligence. Business law today, Vol. 6, No. 3 (jan./fev. 1997).

CLARK, Timothy M.; INGRASIN, Tracie E.; MALONE, Jesse E. The rising tide: navigating the seas of secondary transactions. The investment lawyer, vol. 22, n. 7, jul./2015.

CLIFFORD, John F.; JONKHART, Freek; PEARLMAN, Jessica. What's the market for that cross-border deal? The European, US and Canadian private target M\&A deal points studies. Business Law international, vol. 12, n. 2, mai./2011.

COLEMAN, Jules L. A bargaining theory approach to default and disclosure provisions in contract law. Harvard Journal of Law \& Public Policy, vol. 12, 1989.

COMIRAN, Giovana Cunha. A exegese do art. 425 do Código Civil e o método tipológico: notas sobre critérios hermenêutico-integrativos dos contratos atípicos. in: MOTA, Maurício; KLOH, Gustavo (Org.) Transformações contemporâneas do direito das obrigações. Rio de Janeiro: Elsevier, 2011.

COMPARATO, Fábio Konder. Obrigações de meios, de resultado e de garantia. Revista dos Tribunais, ano 56, dez. 1967, vol. 386.

. O seguro de crédito: estudo jurídico. São Paulo: Max Limonad, 1968.

; SALOMÃO FILHO, Calixto. O poder de controle na sociedade anônima. $6^{\mathrm{a}}$ ed., rev. e atual. Rio de Janeiro: Forense, 2014.

COSTANZA, Maria. Il contratto atipico. Milão: Giuffrè, 1981.

COURTNEY, Wayne. Contractual indemnities. Oxford: Hart Publishing, 2014.

COUTO E SILVA, Clóvis V. do. A obrigação como processo. Rio de Janeiro: Editora FGV, 2006.

COZIAN, Maurice; VIANDIER, Alain; DEBOISSY, Florence. Droit des sociétés. $19^{\mathrm{a}}$ ed. Paris: LexisNexis, 2006.

CRASWELL, Richard. Taking information seriously: misrepresentation and non disclosure in contract law and elsewhere. Virginia Law Review, vol. 92, n. 4, jun./2006. 
CUMMING, Elizabeth. Balancing the buyer's right to recover for precontractual misstatements and the seller's ability to disclaim express warranties. Minnesota Law Review, vol. 76, mai./1992.

D’AMICO, Giovanni. "Regole di validità" e principio di correttezza nella formazione del contratto. in: pubblicazioni della facoltà di giurisprudenza di Catanzaro, vol. 34. Nápoles: Edizioni Scientifiche Italiane, 1996.

DANET, Didier. Cession de droits sociaux: information préalable ou garantie des vices? Revue trimestrielle de droit commercial et de droit écnomique, n. 2, abr./jun. 1992.

DANTAS, San Tiago. Problemas de direito positivo: estudos e pareceres. $2^{\text {a }}$ ed. Rio de Janeiro: Forense, 2004.

DAUD, Fuad José. Transmissão de contrato. São Paulo: Ed. Referência, 2006.

DAUNER-LIEB, Barbara; THIESSEN, Jan. Garantiebeschränkungen in Unternehmenskaufverträgen nach der Schuldrechtsreform. Zeitschrift für Wirtschaftsrecht, 2002.

DAWSON, Frank Griffith; STYLLIS, Stella. Beyond the pitfalls of bad contract drafting practices: a selection of cross-border legal and cultural misunderstandings. Business Law Review, 2007, n. 28, p. 26-29.

DE NOVA, Giorgio. Il sale and purchase agreement: un contratto commentato. $2^{\mathrm{a}}$ ed atual. Turim: Giappichelli, 2016.

DERZI, Misabel de Abreu Machado. Direito Tributário, Direito Penal e Tipo. $2^{\mathrm{a}}$ ed. rev. atual. e ampl. São Paulo: Editora Revista dos Tribunais, 2007.

DIERKSMEIER, Jochen. Der Kauf einer englischen "Private Limited Company". Heidelberg: Verlag Recht und Wirtschaft, 1997.

DUTRA, Erika Donin. Cláusula de limitação de responsabilidade civil nos contratos empresariais: extensão e limites. Dissertação (Mestrado em Direito) - Faculdade de Direito, Universidade Federal do Rio Grande do Sul, 2018. 
DUTRA, Rafael d'Avila; ROSSINI, Flávio Augusto Carvalho da Fonseca. Passivos ocultos em contratos de compra e venda de ações. Revista do Advogado, ano XXXII, n. 116, jul./2012.

ÉDITIONS FRANCIS LEFEBVRE. Cession de parts et actions 2013-2014. Levallois: Éditions Francis Lefebvre, 2012.

EIDENMÜLLER, Horst. Rechtskauf und Unternehmenskauf. Zeitschrift für das gesamte Schuldrecht 8, 2002, p. 290-296.

EISENBERG, Melvin A. Disclosure in contract law. California Law Review, vol. 91, 2003.

EIZIRIK, Nelson Laks. A lei das S/A comentada. Vol. II: artigos 121 a 188. São Paulo: Quartier Latin, 2011.

ENGISCH, Karl. Die Idee der Konkretisierung in Recht und Rechtswissenschaft unserer Zeit. Heidelberg: Carl Winter Universitätsverlag, 1953.

EREDE, Sergio. Durata delle garanzie e conseguenze della loro violazione. in: Acquisizioni di società e di pacchetti azionari di riferimento, a cura di BONELLI, Franco e DE ANDRÈ, Mauro (orgs.) Milão: Giuffrè, 1990.

. I contenuti tipici dei contratti di compravendita internazionale di partecipazioni societarie: representations, indemnities, legal opinions. in: DRAETTA, Ugo (org.), Compravendite internazionali di partecipazioni societarie. Milão: EGEA, 1990.

ESPÍNOLA, Eduardo. Manual do código civil brasileiro. Vol. 3. Parte 2. Rio de Janeiro: Jachinto Ribeiro dos Santos, 1926.

ESSER, Josef; WEYER, Hans-Leo. Schuldrecht. Vol. 2. Tomo 1: contratos. $8^{\mathrm{a}}$ ed. Heidelberg: C. F. Müller Verlag, 1998.

FABRE-MAGNAN, Muriel. De l'obligation d'information dans les contrats - essai d'une théorie. Paris: LGDJ, 1992.

FARNSWORTH, E. Allan. Contracts. $4^{\mathrm{a}}$ ed. Nova Iorque: Aspen, 2004. Precontractual liability and preliminary agreements: fair dealing and failed negotiations. Columbia Law Review, vol. 87, n. 2, mar./1987. 
FAUST, Florian. Garantie und Haftungsbeschränkung in $§ 444$ BGB. Zeitschrift für das gesamte Schuldrecht 2002.

FERERA, Leon N.; PHILIPS, John R.; RUNNICLES, John; SCHWARTZ, Jeffery D. Some differences in law and practice between U.K. and U.S. stock purchase agreements. Disponível em: http://www.mondaq.com/uk/x/47706/Contract+Law/Some+Differences+In+Law+And+Pra ctice+Between+UK+And+US+Stock+Purchase+Agreements. Acesso em 10.2.2018.

FERREIRA DA SILVA, Jorge Cesa. Adimplemento e extinção das obrigações. in: REALE, Miguel; MARTINS-COSTA, Judith (coords.), estudos em homenagem ao professor Miguel Reale. Vol. 6. São Paulo: Revista dos Tribunais, 2007.

Inadimplemento das obrigações. in: REALE JR., Miguel; MARTINSCOSTA, Judith (coords.), estudos em homenagem ao professor Miguel Reale, vol. 7. São Paulo: Revista dos Tribunais, 2007.

FERREIRA DA SILVA, Luís Renato. Do dolo. in: NANNI, Giovanni Ettore; LOTUFO, Renan (coords.) Teoria Geral do Direito Civil. São Paulo: Atlas, 2008.

FERRER CORREIA, Antonio de Arruda. Erro e interpretação na teoria do negócio jurídico. Coimbra: Arménio Amado, 1939.

FERRIEL, Jeffrey; NAVIN, Michael. Understanding contracts. Nova Iorque: Lexis Nexis, 2004.

FLEISCHER, Holger; KÖRBER, Torsten. Due Diligence und Gewährleistung beim Unternehmenskauf. Betriebs-Berater 2001.

FLUME, Werner. Eigenschaftsirrtum und Kauf. Münster: Regensberg, 1948.

FRANÇA, Erasmo Valladão Azevedo e Novaes. Empresa, empresário e estabelecimento. A nova disciplina das sociedades. Revista do Advogado, 2003, n. 71, p. 15-25.

A sociedade em comum. São Paulo: Malheiros, 2013.

Conflito de Interesses nas Assembleias de S.A. (e outros escritos sobre conflito de interesses). $2^{\text {a }}$ ed. rev. e aum. São Paulo: Malheiros, 2014. 
FRANCIOSI, Laura M. Trattative e due diligence: tra culpa in contrahendo e contratto. in: quaderni di responsabilitá civile e previdenza, vol. 17. Milão: Giuffrè, 2009.

FRANCO, Vera Helena de Mello. Lições de direito securitário: seguros terrestres privados. São Paulo: Maltese, 1993.

FREYRIA, Charles. Réflexions sur la garantie conventionnelle dans les actes de cession de droits sociaux. La Semaine Juridique Entreprise et Affaires, n. 20, 1992, p. 146.

FRITZEN, Roland. Unternehmenskauf, Due Diligence und Garantien nach der Schuldrechtsreform. Munique: Martin Meidenbauer, 2004.

FROME, Robert L. Representations and warranties in agreements. New York law journal, vol. 192, n. 122, 27.12.1984, p. 1.

FURMSTON, Michael. Cheshire, Fifoot and Furmston's Law of contract. Oxford: Oxford University Press, 2017.

GALGANO, Francesco. Diritto civile e commerciale. Vol. 2, tomo 1. Pádua: CEDAM, 1990 .

Tratatto di diritto civile. Volume secondo. $3^{\mathrm{a}}$ ed. atual. (atualizadora Nadia Zorzi Galgano). Pádua: CEDAM: Wolters Kluwer, 2015.

GALIA-BEAUCHESNE, Anne. Les clauses de garantie du passif dans les cessions d'actions et des parts sociales. Revue des Sociétés, 1980.

GARNER, Bryan A. Indemnify and hold harmless; save harmless. 15 Green Bag 2d 17.

GAUL, Björn. Schuldrechtsmodernisierung und Unternehmenskauf. Zeitschrift für das gesamte Handels- und Wirtschaftsrecht, 2002, n. 166, p. 35-71.

GAZMURI, Iñigo de la Maza. Los límites del deber precontractual de información. Pamplona: Thomson Reuters, 2010.

GELTMAN, Elizabeth Glass. Shifting the environmental risk: a guide to drafting contracts and structuring transactions. Chicago: ABA Publishing, 1999.

GERGEN, Mark P. Negligent misrepresentation as contract. California Law Review, vol. $101,2013$. 
GHESTIN, Jacques. Droit civil: les obligations, le contrat. Paris: LGDJ, 1980.

GIAMMARINARO, Corrada. Il problema della qualificazione del mutuo di scopo. in: Tipicità e atipicità nei contratti. Quaderni di giurisprudenza commerciale, vol. 53. Milão: Giuffrè.

GILSON, Ronald J. Value creation by business lawyers: legal skills and asset pricing. Yale Law Journal, vol. 94, 1984.

GODOY FERNANDES, André de. Brazil. in: CAMPBELL, Dennis (org.) Mergers and acquisitions in North America, Latin America, Asia and the Pacific: selected issues and jurisdictions. Special issue, volume B. Alphen aan den Rijn: Wolters Kluwer, 2011.

GOLDBERG, Richard A. A guide to mergers \& acquisitions. Nova Iorque: Practising Law Institute, 2007.

GOLDBERG, Victor P. Protecting reliance. Columbia Law Review, vol. 114, n. 4, mai./2014.

GOMES, Orlando. Introdução ao direito civil. $19^{\mathrm{a}}$ ed. rev. atual. e aum. Atualizado por Edvaldo Brito e Reginalda Paranhos de Brito. Rio de Janeiro: Forense \& Gen, 2008.

Obrigações. $17^{\mathrm{a}}$ ed. rev. atual. e aum. por BRITO, Edvaldo. Rio de Janeiro: Forense, 2008.

GONÇALVES NETO, Alfredo de Assis. Direito de empresa: comentários aos artigos 966 a 1.195 do Código Civil. São Paulo: Revista dos Tribunais, 2007.

GRASSI, Ugo. I vizi della cosa venduta nella dottrina dell'errore: il problema dell'inesatto adempimento. Nápoles: Edizioni Scientifiche Italiane, 1996.

GRECO, Paolo. Le società di "comodo" e il negozio indiretto. Rivista del Diritto Commerciale e del Diritto Generale delle Obbligazioni, 1932, vol. XXX, p. 757-808.

GRECO, Paolo; COTTINO, Gastone. Della vendita art. 1470-1547. in: SCIALOJA, Antonio; BRANCA, Giuseppe (orgs.), Commentario del codice civile. Libro quarto: delle obbligazioni. $2^{\text {a }}$ ed. Bologna: Zanichelli, 1981.

GRIGOLEIT, Hans Christoph. Vorvertragliche Informationshaftung: Vorsatzdogma, Rechtsfolgen, Schranken. Munique: C. H. Beck’sche Verlagsbuchhandlung, 1997. 
GRONSTEDT, Sebastian; JÖRGENS, Stefan. Die Gewährleistungshaftung bei Unternehmensverkäufen nach dem neuen Schuldrecht. Zeitschrift für Wirtschaftsrecht 2002.

HAAS, Steven M. Contracting around fraud under Delaware Law. Delaware Law Review, vol. 10, 2008.

HADDING, Walther. Verfügungen über die Mitgliedschaftsrechte. in: BAUR, Jürgen et al. (orgs.). Festschrift für Ernst Steindorff zum 70. Geburtstag am 13. März 1990. Berlim: Walter de Gruyter, 1990.

HAICAL, Gustavo. Cessão de crédito: existência, validade e eficácia. São Paulo: Saraiva, 2013.

HANKE, Kerstin; SOCHER, Oliver. Fachbegriffe aus M\&A und Corporate Finance: dis Gestaltung des Unternehmenskaufvertrags. Neue juristische Wochenschrift, 2010, p. 1576.

HARRISON, Christopher S. Make the deal: negotiating mergers and acquisitions. Nova Jérsei: Bloomberg Press, 2016.

HARRISON, Jeffrey L. Rethinking mistake and nondisclosure in contract law. University of Florida Legal Studies, Research Paper No. 2009-15.

HARTUNG, Manfred. Wissenszurechnung beim Unternehmenskauf. Neue Zeitschrift für Gesellschaftsrecht, 1999, p. 524-531.

HASSETT, Dan; CIRILLO, Greg. Conducting due diligence in business acquisitions involving personal information. The practical lawyer, vol. 48, mar./2002.

HAUSMANN, Christian; TORRE, Philippe. Cessions d'entreprises: les garanties de passif. Négociations et rédaction des conventions de garantie. Cahors: Édtions EFE, 1996.

HEMINWAY, Joan MacLeod; HAMILTON, Angela Humphreys. Buying assets in Tennessee: an annotated model Tennessee asset purchase agreement. The Tennessee Journal of Business Law, vol. 4, 2003

; GENTLE, Terry W. Buying stock in Tennessee: an annotated model Tennessee stock purchase agreement. The Tennessee Journal of Business Law, vol. 5, 2004 
HERMANNS, Marc. Garantien beim Unternehemens- und Anteilskaufvertrag Gestaltungsmöglichkeiten und Formulierungsvorschläge. Zeitschrift für Wirtschaftsrecht, n. 16,2002 , p. 696-700.

HESS, Gerhard; FABRITIUS, Andreas. Unternehmenskauf. in: HOPT, Klaus J (org.). Vertrags- und Formularbuch zum Handels-, Gesellschafts-, Bank- und Transportrecht. Munique: C. H. Beck'sche Verlagsbuchhandlung, 1995.

HIDDEMAN, Hans-Joachim. Leistungsstörungen beim Unternehmenskauf aus der Sicht der Rechtsprechung. Zeitschrift für Unternehmens- und Gesellschaftsrecht 3, 442.

HILGARD, Mark. Berechnung des Schadens bei Verletzung von Garantien eines Unternehmenskaufvertrages. Zeitschrift für Wirtschaftsrecht, n. 41, 2005, p. 1813-821.

; KRAAYVANGER, Jan. Unternehmenskauf - Rechtsfolgen eines selbstständigen Garantieversprechens nach der Reform. Monatsschrift für deutsches Recht, 2002, p. 678-683.

HOFFER, Stephanie R. Misrepresentation: the restatement`s second mistake. University of Illinois Law Review, 2014, vol. 1.

HOMMELHOFF, Peter. Zur Abgrenzung von Unternehmenskauf und Anteilserwerb. Zeitschrift für Unternehmens- und Gesellschaftsrecht 3.

HÜBNER, Rudolf Matthias. Schadensersatz wegen Täuschung beim Unternehmenskauf. Betriebsberater, n. 25, 2010, p. 1483.

HUET, Jérôme; DECOCQ, Georges; GRIMALDI, Cyril; LÉCUYER, Hervé. Traité de droit civil: les principaux contrats speciaux. $3^{\mathrm{a}}$ ed. Paris: L.G.D.J., 2012.

HUNTER, Howard O. Modern law of contracts. Vol. 1. West Publishing, 2012.

INTERNATIONAL BAR ASSOCIATION. Negotiated M\&A Guide - Brazil. Corporate and M\&A Law Committee, TEIXEIRA, Maria P. Q. Brandão (coord.), 2017. Disponível em https://www.ibanet.org/Document/Default.aspx?DocumentUid=ACA29A74-235F40E3-A24C-134ACE1E0362.

IORIO, Giovanni. Struttura e funzioni delle clausole di garanzia nella vendita di partecipazioni sociali. Milão: Giuffrè, 2006. 
JAGERSBERGER, Barbara. Die Haftung des Verkäufers beim Unternehemens- und Anteilskauf. Baden-Baden: Nomos Verlag, 2006.

JAKOBS, Michael; THIEL, Sven-Markus. Managementerklärungen bei Unternehmenskäufen - Risiken und Absicherung aus Sicht der Geschäftsführung. Betriebs-Berater, 2016, p. 1987-1991.

JOHNSON JR., Alex M. An economic analysis of the duty to disclose information: lessons learned from the caveat emptor doctrine. San Diego Law Review, vol. 45, 2008.

JORDAN, Anne S. Effective remedies: drafting warranties, indemnities, and limitations of liability clauses in technology licenses. The licensing journal, mar./2016.

KARAMPATZOS, Antonios G. Der Umfang der Aufklärungspflicht des Verkäufers beim Unternehmenskauf - Insbesondere die so genannte "Non-Reliance"-Klausel. Neue Zeitschrift für Gesellschaftsrecht, 2012, p. 852-859.

KÄSTLE, Florian; OBERBRACHT, Dirk. Unternehmenskauf - Share Purchase Agreement. Munique: Verlag C. H. Beck, 2005.

KLING, Lou R.; NUGENT, Eileen T. Negotiated acquisitions of companies, subsidiaries, and divisions. Nova Iorque: Law Jounral Press, 1992.

; GOLDMAN, Michael. Summary of acquisition agreements.

University of Miami law review, vol. 51, 1997.

KNOTT, Hermann; MIELKE, Werner. Unternehmenskauf. $3^{\text {a }}$ ed. Colônia: RWS Verlag, 2008 .

KOLLER, Arnold. Grundfragen einer Typuslehre im Gesellschaftrecht. Friburgo: Universitätsverlag Freiburg Schweiz, 1967.

KOLLER, Ingo. Die Haftung beim Verkauf von Verträgen. Juristische Rundschau, 1982, Caderno 9, p. 353.

KÖSTER, Christian. Die Haftung des Unternehmensverkäufers für falsche Abschlussangaben nach neuem Schuldrecht. Frankfurt am Main: Peter Lang, 2005.

KRAIEM, Ruben. Leaving money on the table: contract practice in a low-trust environment. Columbia Journal of Transnational Law, vol. 42, 2004. 
KRONMAN, Anthony T. Mistake, disclosure information and the law of contracts. The Journal of Legal Studies, 1978.

KWESTEL, Sidney. Express warranty as contractual - the need for a clear approach. Mercer Law Review, 2002, n. 53, p. 557-580.

LANDIM, Jayme. Vícios da vontade: erro. Rio de Janeiro: José Konfino editor, 1960.

LARENZ, Karl. Lehrbuch des Schuldrechts. Band II, Halbband 1. Besonderer Teil. 13 ${ }^{\mathrm{a}}$ ed. Munique, C.H. Beck, 1986.

Allgemeiner Teil des bürgerlichen Rechts. $9^{a}$ ed. Munique: Verlag C. H. Beck, 2004.

; CANARIS, Claus-Wilhelm. Methodenlehre der Rechtswissenschaft. $3^{\mathrm{a}}$ ed. Berlim; Heidelberg; Nova York; Barcelona; Budapeste; Hong kong; Londres; Milão; Paris; Tokyo: Springer Verlag, 1995.

LARISCH, Tobias. Gewährleistungshaftung beim Unternehmens- und Beteiligungskauf. Colônia: Verlag Dr. Otto Schmidt, 2004.

LE CANNU, Paul; DONDERO, Bruno. Droit des sociétés. $4^{\mathrm{a}}$ ed. Montchrestien, 2011.

LEÃES, Luiz Gastão Paes de Barros. Sociedade por cotas - cota social - penhorabilidade comentário do Prof. Luiz Gastão Paes de Barros Leães. Revista de direito mercantil, industrial, econômico e financeiro, ano XI, Nova Série, n. 5, 1972.

LÉOBON, Thierry. La partie déclarative des conventions de garantie de passif. La Semaine Juridique Entreprise et Affaires, n. 16, 2010, p. 1391.

LEVENEUR, Laurent. Distinction des vices cachés et des manquements à l'obligation de délivrance. La Semaine Juridique Edition Générale, n. 51, 1994, p. 607.

LEVIN, Edward J. Best is not always best when it comes to knowledge. Probate and property, vol. 30, n. 1, 2016.

LEVINE, Mark L. Including representations and warranties in contracts. New York Law Journal, 20.1.1989, p. 1. 
LEVMORE, Saul. Securities and secrets: insider trading and the law of contracts. Virginia Law Review, vol. 68, 1982.

LIMA, Otto de Sousa. Teoria dos vícios redibitórios. São Paulo: Revista dos Tribunais, 1965.

LIMA MARQUES, Cláudia. Contratos no código de defesa do consumidor: o novo regime das relações contratuais. $8^{a}$ ed. rev. atual. e ampl. São Paulo: Revista dos Tribunais, 2016.

LIPSHAW, Jeffrey M. Of fine lines, blunt instruments and half-truths: business acquisition agreements and the right to lie. Delaware Journal of Corporate Law, vol. 32, 2007.

LOBO, Paulo Luiz Netto. Comentários ao Código Civil. Vol. 6. Parte especial: das várias espécies de contrato: arts. 481 a 564. São Paulo: Saraiva, 2003.

LOPES, João Batista. Desconsideração da personalidade jurídica no novo Código Civil. Revista dos tribunais, n. 818, a. 92, dez./2003.

LUMINOSO, Angelo. Corso di diritto civile: la compravendita. $4^{\text {a }}$ ed. Turim: Giappichelli, 2014.

LUTTER, Marcus. Theorie der Mitgliedschaft. Archiv für die civilistische Praxis, vol. 180, ano 1980 .

Due Diligence des Erwerbers beim Kauf einer Beteiligung. Zeitschrift für Wirtschaftsrecht 1997.

MAGALHÃES, Ana Alvarenga Moreira. O erro no negócio jurídico: autonomia da vontade, boa-fé objetiva e teoria da confiança. São Paulo: Atlas, 2011.

MALAURIE, Philippe; LAURENT, Aynès. Cours de droit civil. Tome VI: les obligations. Paris: éditions cujas, 1995.

; _ _ GAUTIER, Pierre-Yves. Droit civil: droit des contrats spéciaux. 9ª ed. Paris: LGDJ, 2017.

MARINO, Francisco Paulo de Crescenzo. Interpretação do Negócio Jurídico. São Paulo: Saraiva, 2011. 
MARROCCO, Andrae J. Negotiating critical representations and warranties in franchise mergers and acquisitions - part I. Franchise law journal, vol. 36, n. 1, 2016.

MARTINS, João Marcos de Brito. O contrato de seguro. Rio de Janeiro: Forense Universitária, 2003.

MARTINS, Maria Inês de Oliveira. O seguro de vida enquanto tipo contratual legal. Coimbra: Coimbra Editora, 2010.

MARTINS-COSTA, Fernanda Mynarski. Condição suspensiva: função, estrutura e regime jurídico. São Paulo: Almedina, 2017.

MARTINS-COSTA, Judith. Comentários ao novo código civil. Vol. V, tomo I: do direito das obrigações. Do adimplemento e da extinção das obrigações (arts. 304 a 388). $2^{\mathrm{a}}$ ed. Rio de Janeiro: Forense, 2006.

. Comentários ao novo código civil. Vol. V, tomo II: do inadimplemento das obrigações (arts. 389 a 420). $2^{a}$ ed. Rio de Janeiro: Forense, 2009.

. Os contratos de leasing financeiro, a qualificação jurídica da parcela denominada valor residual garantido - VRG e a sua dupla função: complementação do preço e garantia. Revista de direito bancário e do mercado de capitais, vol. 49, jul.-2010.

. Os regimes do dolo no direito civil brasileiro: dolo antecedente, vício informativo por omissão e por comissão, dolo acidental e dever de indenizar. Revista dos tribunais, vol. 923, set./2012.

. Contrato de Construção. Contrato-Aliança. Interpretação Contratual. Cláusulas de Exclusão e de Limitação do Dever de Indenizar (parecer). Revista de Direito Civil Contemporâneo, ano 1, vol. 1, out-dez/2014.

Autoridade e utilidade da doutrina: a construção dos modelos doutrinários. in: MARTINS-COSTA, Judith (org.), Modelos de Direito Privado. São Paulo: Marcial Pons, 2014.

A boa-fé no direito privado: critérios para a sua aplicação. São Paulo: Marcial Pons, 2015. 
; ZANETTI, Cristiano de Sousa. Responsabilidade contratual: prazo prescricional de dez anos. Revista dos Tribunais, vol. 979, mai./2017.

MARTORANO, Federico. La tutela del compratore per i vizi della cosa. Nápoles: Editore Jovene, 1959.

MASTROPAOLO, Fulvio. I contratti autonomi di garanzia. Turim: Giappichelli, 1989.

MCKENDRICK, Ewan. Contract: in general. in: BURROWS, Andrew (ed.). Principles of the English Law of obligations. Oxford: Oxford University Press, 2015

MCMEEL, Gerard. The construction of contracts: interpretation, implication and rectification. $2^{\mathrm{a}}$ ed. Oxford: Oxford University Press, 2011.

MEDICUS, Dieter. Bürgerliches Recht. 17ª ed. Munique: Carl Heymanns Verlag, 1996.

MELLERT, Christofer Rudolf. Selbständige Garantien beim Unternehmenskauf Auslegungs- und Abstimmungsprobleme. Betriebs-Berater, 2011, p. 1667-1674.

MELLO, Marcos Bernardes de. Teoria do fato jurídico. Plano da validade. $13^{a}$ ed. São Paulo: Saraiva, 2013.

. Teoria do fato jurídico. Plano da validade. $7^{a}$ ed. São Paulo: Saraiva, 2006.

MENDES-MEDEIROS, Mariana. Cláusulas de declarações e garantias nos contratos internacionais de aquisição de empresas ou ativos. Dissertação (Mestrado em Direito) Faculdade de Direito, Universidade de São Paulo, São Paulo, 2006.

MICHELON JR., Cláudio Fortunato. Direito Restituitório. in: REALE, Miguel; MARTINS-COSTA, Judith (coords.), estudos em homenagem ao professor Miguel Reale. Vol. 8. São Paulo: Revista dos Tribunais, 2007.

MILLER, Robert T. The economics of deal risk: allocating risk through MAC clauses in business combination. William and Mary law review, vol. 50, 2007.

MILLER JR., Edwin L. Mergers and acquisitions: a step-by-step legal and practical guide. Nova Jérsei: John Wiley \& Sons, 2008. 
MIRMINA, Steven A. A comparative survey of culpa in contrahendo, focusing on its origins in Roman, German and French Law, as well as its application in American Law. Connecticut Journal of International Law, vol. 8, 1992.

MIZIOLEK, Aleksandra; ANGELAKOS, Dimitrios. Contract drafting: sandbagging: from poker to the world of mergers and acquisitions. Michigan Bar Journal, 2013, vol. 92, p. 30-34.

MOREIRA ALVES, José Carlos. A parte geral do projeto de código civil brasileiro. $2^{\mathrm{a}}$ ed. São Paulo: Saraiva, 2003.

MOTA PINTO, Carlos Alberto da. Cessão da posição contratual. Reimpressão. Coimbra: Almedina, 2003.

MOTA PINTO, Paulo. Interesse contratual negativo e interesse contratual positivo. Vol. II. Coimbra: Coimbra Editora, 2008.

MOUSSERON, Pierre. Les conventions de garantie dans les cessions de droits sociaux. Levallois-Perret: Nouvelles Éditions Fiduciaires - nef'université, 1992.

. L'obligation de renseignement dans les cessions de contrôle. La Semaine Juridique Entreprise et Affaires, n. 22, 1994, p. 362.

MÜLLER, Klaus. Unternehmenskauf, Garantie und Schuldrechtsreform - ein Sturm im Wasserglas? Neue juristische Wochenschrift, 2002, p. 1026.

Einfluss der due diligence auf die Gewährleistungsrechte des Käufers beim Unternehmenskauf. Neue juristische Wochenschrift, 2004, p. 2196.

MUNHOZ, Eduardo Secchi. Desconsideração da personalidade jurídica e grupos de sociedades. Revista de direito mercantil, industrial, econômico e financeiro, n. 134, a. XLIII, abr.-jun./2004.

NASCIMENTO, Sérgio dos Santos. Cessão da posição contratual. Dissertação (Mestrado em Direito) - Faculdade de Direito, Universidade de São Paulo, São Paulo, 2015.

NORONHA, Fernando. Direito das obrigações. $3^{\text {a }}$ ed. rev. e atual. São Paulo: Saraiva, 2010. 
NOTTÉ, Gérard. Les clauses dites "de garantie de passif” dans les cessions de droits sociaux. La Semaine Juridique (Edition Génerale), n. 22, 1985, n. 3193.

OLIVEIRA, Marcia Cicarelli Barbosa de. O interesse segurável. Dissertação (Mestrado em Direito) - Faculdade de Direito, Universidade de São Paulo, São Paulo, 2011.

O'SULLIVAN, Dominic; ELLIOTT, Steven; ZAKRZEWSKI, Rafal. The law of rescission. 2a ed. Oxford: Oxford University Press, 2014.

OTT, Walter. Die Problematik einer Typologie im Gesellschaftsrecht, dargestellt am Beispiel des schweizerischen Aktienrechts. Berna: Verlag Stämpfli \& Cie AG, 1972.

PAILLUSSEAU, Jean. Le bénéficiaire de la garantie de passif dans la cession de controle. La Semaine Juridique - Édition Générale, n. 6, 2002 ; CAUSSAIN, Jean-Jacques; LAZARSKY, Henri; PEYRAMAURE, Philippe. Cession d'entreprise. $4^{\mathrm{a}}$ ed. Paris: Dalloz, 1999.

PALANDT. Beck'sche Kurzkommentare Bürgerliches Gesetzbuch mit Nebengesetzen. $75^{\mathrm{a}}$ ed. Munique: C.H. Beck, 2016.

PARTIGAN, John; LOWRY, Carolyn; HAN, Pierce. Key findings from 2017 survey of M\&A indemnification deal terms. Insights, vol. 31, n. 12, dez./2017.

PAYNE, Bill. Representations, reliance and remedies: the legacy of Hendricks v. Callahan. Bench \& Bar of Minnesota - Official Publication of the Minnesota State Bar Association, 2005, vol. 62, n. 8 .

PEDERSOLI, Alessandro. Le garanzie fiscali, previdenziali ed ecologiche. in: Acquisizioni di società e di pacchetti azionari di riferimento, a cura di BONELLI, Franco e DE ANDRÈ, Mauro (orgs.) Milão: Giuffrè, 1990.

PEDREIRA, José Luiz Bulhões; LAMY FILHO, Alfredo. Ação como participação societária. in: PEDREIRA, José Luiz Bulhões; LAMY FILHO, Alfredo (coords.) Direito das companhias. Vol. 1. Rio de Janeiro: Forense \& Gen, 2009.

PEREIRA, Guilherme Döring Cunha. Alienação do poder de controle acionário. São Paulo: Saraiva, 1995. 
PEREIRA, Regis Fichtner. A responsabilidade civil pré-contratual: teoria geral e responsabilidade pela ruptura das negociações contratuais. Rio de Janeiro: Renovar, 2001.

PERILLO, Joseph. M. Calamari and Perillo on contracts. $5^{\text {a }}$ ed. Saint Paul: West Publishing, 2003.

PETTARIN, Guido Germano. Acquisizione, fusione e scissione di società. Milão: Giuffrè, 1992.

PETITPIERRE, Anne. La cession de contrôle, mode de cessino de l'entreprise. Genebra: Georg \& Cie. S.A., 1977.

PICOT, Gerhard. Unternehmenskauf und Restrukturierung. $3^{\mathrm{a}}$ ed. Munique: C.H. Beck, 2004.

PISTORELLI, Roberto. Le garanzie "analitiche" sulle voci della situazione patrimoniale di riferimento. in: Acquisizioni di società e di pacchetti azionari di riferimento, a cura di BONELLI, Franco e DE ANDRÈ, Mauro (orgs.) Milão: Giuffrè, 1990.

PIZA, Paulo Luiz de Toledo. Contrato de resseguro: tipologia, formação e direito internacional. São Paulo: IBDS, 2002.

PLC What's Market Wrap-up for the Week Ending September 14, 2012. Disponível em: https://us.practicallaw.com/7-521-3696. Acesso em 19.2.2018.

PONTAVICE, Emmanuel du. Note Cass. Com. 3 avril 1979. Revue des Sociétés, 1980, p. 723.

PONTES, Evandro Fernandes de. Representations \& warranties no direito brasileiro. São Paulo: Almedina, 2014.

PONTES DE MIRANDA, Francisco Cavalcanti. Tratado de direito privado. Tomo III. Atualizado por Marcos Bernardes de Mello e Marcos Ehrhardt Jr. São Paulo: Revista dos Tribunais, 2012.

Tratado de direito privado. Parte geral. Tomo IV. Atualizado por Marcos Bernardes de Mello e Marcos Ehrhardt Jr. São Paulo: Revista dos Tribunais, 2013. . Tratado de direito privado. Tomo V. Atualizado por Marcos Bernardes de Mello e Marcos Ehrhardt Jr. São Paulo: Revista dos Tribunais, 2013. 
. Tratado de direito privado. Tomo XXIII. Atualizado por Nelson Nery Jr. e Rosa Maria de Andrade Nery. São Paulo: Revista dos Tribunais, 2012. . Tratado de direito privado. Tomo XXXVIII. Atualizado por Claudia Lima Marques e Bruno Miragem São Paulo: Revista dos Tribunais, 2012. . Tratado de direito privado. Tomo XXXIX. Atualizado por Cláudia Lima Marques. São Paulo: Revista dos Tribunais, 2012.

POUSTIS, Jean; MONNOT, Jean-Louis. La garantie dans les cessions de droits sociaux (panorama de jurisprudence). La Semaine Juridique Entreprise et Affaires, n. 17, 1985, p. 14464.

; L La garantie dans les cessions de droits sociaux (étude d'actualité). La Semaine Juridique Entreprise et Affaires, n. 17, 1989, p. 15479.

PRATA, Ana. Cláusulas de exclusão e limitação da responsabilidade contratual. Coimbra: Almedina, 2005.

RADÉ, Christophe. L'autonomie de l'action en garantie des vices cachés. La semaine juridique édition générale, n. 12, 1997.

RÁO, Vicente. Ato jurídico. $4^{\mathrm{a}}$ ed. an., rev. e atual. Ovídio Rocha Barros Sandoval (atualizador) São Paulo: Revista dos Tribunais, 1999.

REINICKE, Dietrich; TIEDTKE, Klaus. Kaufrecht. 6ª ed. Berlim: Luchterhand, 1997.

RENNA, Luca. Compravendita di partecipazioni sociali. Dalla lettera di intenti al closing. Bologna: Zanichelli, 2015.

REQUIÃO, Rubens. Abuso de direito e fraude através da personalidade jurídica. Revista dos Tribunais, n. 410, a. 58, dez./1969, p. 12-25.

Curso de direito comercial. Vol. 1. 30ª ed. rev. e atual. São Paulo: Saraiva, 2011.

RIBEIRO, Amadeu Carvalhaes. Direito de seguros: resseguro, seguro direto e distribuição de serviços. São Paulo: Atlas, 2006. 
RICHARD, Jacques. Le choix du bénéficiaire de la garantie de passif. La Semaine Juridique Entreprise et Affaires, n. 5, 1991, p. 19.

RIPERT, Georges; ROBLOT, René. Traité de droit commercial. Tomo 1, vol. 2: les sociétés commerciales. $18^{\mathrm{a}}$ ed. Paris: LGDJ, 2002.

RITTMEISTER, Maximilian. Gewährleistung beim Unternehmenskauf. Frankfurt am Main: Peter Lang, 2005.

RIZZARDO, Arnaldo. Leasing: arrendamento mercantil no direito brasileiro. $5^{\mathrm{a}}$ ed. rev. atual e ampl. São Paulo: Editora Revista dos Tribunais, 2010.

ROCA, M.-C. Sociétés Anonymes - Cession de contrôle. Cession d'actions. Achat pour le cessionaire de la majorité des actions. Contrat de cession. Dol. Annulation. Dommages et intérêts (non). Comentarios à decisão Versailles, 13e Ch., 17 juin 1987. La Semaine Juridique Entreprise et Affaires, n. 4, 1988, p. 15109.

RODRIGUES, Silvio. Dos vícios do consentimento. São Paulo: Saraiva, 1979.

Direito civil. Vol. 3. Dos contratos e das declarações unilaterais de vontade. $30^{\mathrm{a}}$ ed. São Paulo: Saraiva, 2002.

RODRIGUES JÚNIOR, Otávio Luiz. Compra e venda, troca e contrato estimatório: arts. 481 a 537. in: AZEVEDO, Álvaro Villaça (coord.), código civil comentado. Vol. VI. São Paulo: atlas, 2008.

ROLLI, Rita. Cessioni di partecipazioni societarie e tutela del compratore: aliud pro alio datum? Contratto e impresa, 1994, n. 1, p. 183-238.

ROSENBAUM, Judith A. Transactional drafting: teaching tips. Tennessee Journal of Business Law, n. 14, Transactions, p. 591-602.

ROSENVALD, Nelson; FARIAS, Cristiano Chaves de. Curso de direito civil. Vol. 2: obrigações. $9^{\text {a }}$ ed, rev. atual e ampl. São Paulo: Atlas, 2015.

RUBINO-SAMMARTANO, Mauro. Garanzie nella compravendita di pacchetti azionari e di imprese. Milão: Giuffrè, 2006.

SALATINO, Gregorio. 'Representations and warranties' in sale and purchase agreements: the Italian perspective. Global Trade and Customs Law, 2016, vol. 11, n. 10, p. 440-446. 
SALOMÃO FILHO, Calixto. A sociedade unipessoal. São Paulo: Malheiros, 1995.

SANSEVERINO, Paulo de Tarso Vieira. Princípio da reparação integral: indenização no código civil. São Paulo: Saraiva, 2011.

SAPONE, Natalino. La responsabilità precontrattuale. Milão: Giuffrè, 2008.

SCALZILLI, João Pedro; SPINELLI, Luis Felipe. Sociedade em conta de participação. São Paulo: Quartier Latin, 2014.

SCHEPPELE, Kim Lane. Legal secrets: equality and efficiency in the common law. Chicago: The University of Chicago Press, 1988.

SCHIFFER, Jack; MAYER, Carolin. Sorgfaltspflichten des Verkäufers und des Käufers beim Unternehmenskauf: die neue Rechtsprechung. Betriebs-Berater, 2016, p. 2627-2632.

SCHMIDT, Karsten. Gesellschaftsrecht. $4^{\mathrm{a}}$ ed. atual. e aum. Colônia, Berlin, Bonn, Munique: Carl Heymanns Verlag, 2002.

SCHRÖCKER, Stefan. Unternehmenskauf und Anteilskauf nach der Schuldrechtsreform. Zeitschrift für Unternehmens- und Gesellschaftsrecht 2005.

SCHWAB, Dieter; LÖHNIG, Martin. Einführung in das Zivilrecht. $18^{a}$ ed. Heidelberg: C. F. Müller, 2010.

SCOTT, Robert E.; KRAUS, Jody S. Contract law and theory. $5^{\mathrm{a}}$ ed. Durham: Carolina Academic Press, 2013.

SERFILIPPI, Claude S. A New York lawyer in London: representations and warranties in acquisition agreements - what's the big deal? Artigo publicado no site Lexology, disponível em https://www.lexology.com/library/detail.aspx?g=1d954834-a35d-4470bfa2-bfee233afe41. Acesso em 23 de maio de 2018.

SERPA LOPES, Miguel Maria de. Curso de direito civil. Vol. II: obrigações em geral. $6^{\mathrm{a}}$ ed. rev. e atual. Rio de Janeiro: Freitas Bastos, 1995.

Curso de direito civil. Vol. III. $6^{a}$ ed. rev. e atual. Rio de Janeiro: Freitas Bastos, 1996. 
SILVA, De Plácido e. Vocabulário Jurídico. $31^{\mathrm{a}}$ ed. Atualizado por Nagib Slaibi Filho e Priscila Pereira Vasques Gomes. Rio de Janeiro: Forense, 2014.

SILVA, Eva Sónia Moreira da. Da responsabilidade pré-contratual por violação dos deveres de informação. Coimbra: Almedina, 2006.

As relações entre a responsabilidade pré-contratual por informações e os vícios da vontade (erro e dolo): o caso da indução negligente em erro. Coimbra: Almedina, 2010.

SILVA PEREIRA, Caio Mário da. Instituições de Direitos Civil. Vol. I: introdução ao direito civil, teoria geral do direito civil. $30^{\mathrm{a}}$ ed. rev. e atual. Rio de Janeiro: Forense e Gen, 2017.

Instituições de Direitos Civil. Vol. II: teoria geral das obrigações. 29a ed. rev. e atual. Rio de Janeiro: Forense e Gen, 2017.

Instituições de direito civil. Vol. III: contratos, declaração unilateral de vontade, responsabilidade civil. $21^{\mathrm{a}}$ ed. rev. e atual por Caitlin Mulholland. Rio de Janeiro: 2017.

SINCLAIR, Neil. Sinclair on warranties and indemnities on share and asset sales. $9^{\mathrm{a}}$ ed. Londres: Sweet \& Maxwell, 2014.

SINDE MONTEIRO, Jorge Ferreira. Responsabilidade por conselhos, recomendações ou informações. Coimbra: Almedina, 1989.

SOERGEL, Bürgerliches Gesetzbuch mit Einführungsgesetz und Nebengesetzen. band 3 . Schuldrecht II (§§ 433-515). Stuttgart, Berlin, Colônia: Verlag Kohlhammer, 1991.

SOUZA, Augusto Cesar Barbosa de. Brazil. in: MARTINIUS, Philip (org.), M\&A protecting the purchaser. AIJA Series Book. Zuidpoolsingel: Kluwer Law International, 2004.

STANNARD, John E.; CAPPER, David. Termination for breach of contract. Oxford: Oxford University Press, 2014.

STARCK, Boris; ROLAND, Henri; BOYER, Laurent. Droit Civil. Obligations 2. Contrat. $3^{a}$ ed. paris: Liitec Librairie de la Cour de Cassation, 1988. 
STARK, Tina L. Drafting contracts: how and why lawyers do what they do. Nova Iorque: Aspen Publishers, 2007.

STAUDINGER, Julius von. Kommentar zum Bürgerlichen Gesetzbuch mit Einführungsgesetz und Nebengesetzen. Buch 2: Recht der Schuldverhältnisse §§433-480. Berlim: De Gruyter, 2014.

STENGEL, Arndt; SCHOLDERER, Frank. Aufklärungspflichten beim Beteiligungs- und Unternehmenskauf. Neue juristische Wochenschrift, 1994, p. 158 e ss.

STONE, Richard; DEVENNEY, James. The modern law of contract. 12 $2^{\mathrm{a}}$ ed. Abingdon: Routledge, 2017.

SZTAJN, Rachel. Atipicidade de Sociedades no Direito Brasileiro. São Paulo: PKR Gráfica e Editora, 1987.

TARTAGLIA, Ezio. Acquisto di quote societarie e pacchetti azionari. Clausole di tutela dell'acquirente nel processo di M\&A. Santarcangelo di Romagna: Maggioli, 2014.

TEPEDINO, Gustavo; BARBOZA, Heloisa Helena; MORAES, Maria Celina Bodin de. Código Civil Interpretado conforme a constituição da república. Vol. I. $2^{\mathrm{a}}$ ed. rev. e atual. Rio de Janeiro: Renovar, 2007.

. Código Civil Interpretado conforme a constituição da república. Vol. II. Rio de Janeiro: Renovar, 2006.

TERRÉ, François; SIMLER, Philippe; LEQUETTE, Yves. Droit civil: les obligations. $6^{\mathrm{a}}$ ed. Paris: Dalloz, 1996.

TINA, Andrea. Il contratto di acquisizione di partecipazioni societarie. Milão: Giuffrè, 2007.

TRABUCCHI, Alberto. Istituzioni di diritto civile. 44ª ed. Pádua: CEDAM, 2009.

TRÉBULLE, François Guy. Cession de droits sociaux: mise en oeuvre d'une convention de garantie de passif environnemental. La semaine juridiqe entreprise et affaires, n. 9, 3 de março de 2005.

TREITEL, Günter. The law of contract. 11 ${ }^{\mathrm{a}}$ ed. Londres: Sweet \& Maxwell, 2003. 
TRIEBEL, Volker; HÖLZLE, Gerrit. Schuldrechtsreform und Unternehmenskaufverträge. Betriebs-Berater 2002, 521.

TRIMARCHI, Pietro. Istituzioni di diritto privato. 9ª ed. Milão: Giuffrè, 1991.

TZIRULNIK, Ernesto; CAVALCANTI, Flávio de Queiroz B.; PIMENTEL, Ayrton. O contrato de seguro. $2^{\text {a }}$ ed. rev. atual e ampl. São Paulo: Editora Revista dos Tribunais, 2003.

VALSERRA, Fabrizio. La vendita di quote o di azioni non è vendita di beni sociali. in: Il diritto fallimentare e delle società commerciali, vol. 27, n. 2, 1952.

VANZELLA, Rafael Domingos Faiardo. Numerus clausus dos direitos reais e autonomia nos contratos de disposição. Tese (Doutorado em Direito) - Faculdade de Direito, Universidade de São Paulo, São Paulo, 2009.

VASCONCELOS, Miguel Pestana de. Direito das garantias. $2^{\mathrm{a}}$ ed. Coimbra: Almedina, 2013.

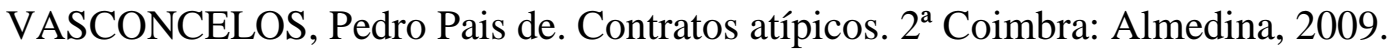

VERÇOSA, Haroldo Malheiros Duclerc. Curso de direito comercial. Vol. 2. $2^{\mathrm{a}}$ ed. rev. e atual. São Paulo: Malheiros, 2010.

VIEHWEG, Theodor. Tópica e Jurisprudência. Trad. de Tércio Sampaio Ferraz Jr. Brasília: Departamento de Imprensa Nacional, 1979.

VON BISMARCK, Nilufer. Corporate acquisitions and merger in the United Kingdom. Zuidpoolsingel: Wolters Kluwer, 2013.

VOSS, Stefan Friedrich. Warranties in Unternehmenskaufverträgen: Struktur und Wirkungsweise anglo-amerikanischer Gewährleistungskataloge in Unternehmenskaufverträgen, die deutschem Recht unterliegen. Tübingen: MVK Medien Verlag Köhler, 2002

WALD, Arnoldo. Dolo acidental do vendedor e violação das garantias prestadas. Revista dos Tribunais, 2014, n. 949, p. 95-103.

WÄCHTER, Gerhard H. Schadensrechtliche Probleme beim Unternehmenskauf: Naturalherstellung und Bilanzgarantien. Neue juristische Wochenschrift, 2013, p. 1270. 
WEIGL, Gerald. Gewährleistungsausschluss und Ansprüche aus c.i.c. Deutsche Notarzeitschrift, 2007, p. 712-716.

WESENDONCK, Tula. Desconsideração da personalidade jurídica: uma comparação do regime adotado no direito civil e no direito tributário. Revista dos tribunais, n. 915, a. 101, jan./2015.

WEST, Glenn D.; LEWIS JR., W. Benton. Contracting to avoid extra-contractual liability can your contractual deal ever really be the "entire" deal? The business lawyer, vol. 64 (agosto-2009).

; DURAN, Sarah G. Reassessing the "consequences" of consequential damage waivers in acquisition agreements. The business lawyer, vol. 63, mai./2008.

.; SHAH, Kim M. Debunking the myth of the sandbagging buyer: when sellers ask buyers to agree to anti-sandbagging clauses, who is sandbagging whom? The $M \& A$ lawyer, vol.11, n. 1, 2007.

WESTERMANN, Harm-Peter. Münchener Kommentar zum Bürgerlichen Gesetzbuch. Band 3: Schuldrecht Besonderer Teil I §§433-534. $7^{\mathrm{a}}$ ed. Munique: C.H. Beck, 2016.

. Das neue Kaufrecht. Neue juristische Wochenschrift, 2002, p. 241.

. Due Diligence beim Unternehmenskauf. Zeitschrift für das gesamte Handelsund Wirtschaftsrecht, n. 169, 2005, p. 248-273.

WHITE, James; SUMMERS, Robert. Uniform commercial code. $6^{\text {a }}$ ed. Saint Paul: West Publishing, 2010

WHITEHEAD, Charles K. Sandbagging: default rules and acquisition agreements. Delaware journal of corporate law, 2011, vol. 36, p. 1081-1115.

WIEDEMANN, Herbert. Die Übertragung und Vererbung von Mitgliedschaftsrechten bei Handelsgesellschaften. Munique: C. H. Beck'sche Verlagsbuchhandlung, 1965.

Die Haftung des Verkäufers von Gesellschaftsanteilen für Mängel des Unternehmens. in: DIETZ, Rolf; HÜBNER, Heinz (orgs.), Festchrift für Hans Carl Nipperdey zum 70. Geburtstag 21. Januar 1965 - Band I. Munique e Berlim: C. H. Beck'sche Verlagsbuchhandlung, 1965, p. 815-836. 
. Gesellschaftsrecht. Vol. I: Grundlagen. Munique: C. H. Beck, 1980

. Gesellschaftsrecht. Vol. II: Recht der Personengesellschaften. Munique: C.

H. Beck, 2004

WILLISTON, Samuel. A treatise on the law of contracts. vol. 11. $4^{\mathrm{a}}$ ed atualizada por Richard Lord. Danvers: West Group, 1999

YOUNGBLOOD JR., D. Hull; FLOCOS, Peter N. Drafting and enforcing complex indemnification provisions. The practical lawyer, ago./2010.

ZUCKERMAN, Tod; MOTZER, William; LEONARD, Alfred; SOLOMON, Hayden. Representing buyers, sellers and lenders in transferring contaminated property: a primer for real estate practitioners. Part I. Real estate, probate and trust journal, vol. 35, n. 2, summer 2000. 


\section{JURISPRUDÊNCIA PESQUISADA}

ALEMANHA

BGH DB, 1980, 679

BGH NJW, 1969, 184

BGH NJW, 1976, 236

BGH NJW 1977, 1536

BGH NJW 1979, 160

BGH NJW, 1980, 2408

BGH, NJW 1990, 1658

BGH, NJW 1995, 1547

BGH NJW, 1998, 302

BGH NJW 1999, 1404

BGH NJW 2002, 2774

BGH NJW-RR 1996, 429

BGH NJW-RR 2002, 308

BGH WM, 1969, 67

BGH WM 1970, 819

BGH WM 1980, 1006

BGH ZIP 1980, 549

BGHZ 13, 179

BGHZ 16, 54

BGHZ 34, 32 
BGHZ 63, 369

BGHZ 65, 246

BGHZ 78, 216

BGHZ 109, 327, 332

BGHZ 132, 30, 36

BGHZ 65, 246

OLG Hamburg WM 1994, 1378

OLG Munique, Decisão de 26.7.2006, 7 U 2128/06

BRASIL

STJ, REsp 161.351/SC, Rel. Min. Waldemar Zveiter, j. 20.8.1998

STJ, REsp 215.832/PR, Rel. Min. Sálvio de Figueiredo Teixeira, j. 6.3.2003

STJ, EREsp n. 213.828/RS, Rel. Min. Edson Vidigal, j. 7.5.2003

STJ, REsp 1.033.241/RS, Rel. Min. Aldir Passarinho Junior, j. 22.10.2008

STJ, REsp 616.069/MA, Rel. Min. João Otávio de Noronha, j. 26.02.2008

STJ, REsp 1.121.243/PR, Rel. Min. Aldir Passarinho Junior, j. 25.08.2009

STJ, REsp 744311/MT, Rel. Min. Luis Felipe Salomão, j. 19.8.2010

STJ, AgRg no REsp 1.101.196/MG, Rel. Min. Massami Uyeda, j. 16.11.2010

STJ, REsp 903.771/SE, Rel. Min. Paulo de Tarso Sanseverino, j. 12.4.2011

STJ, REsp 1.222.423/SP, Rel. Min. Luis Felipe Salomão, j. 15.09.2011

STJ, REsp 1.276.311/RS, Rel. Min. Luis Felipe Salomão, j. 20.09.2011

STJ, REsp 1.150.711/MG, Rel. Min. Luis Felipe Salomão, j. 06.12.2011 
STJ, Ag no REsp 1.057.248/PR, Rel. Min. Sidnei Beneti, j. 26.04.2011

STJ, Ag no AREsp 14.637/RS, Rel. Min. Maria Isabel Gallotti, j. 27.09.2011

STJ, AgRg no Ag 1.401.863/PR, Rel. Min. Antonio Carlos Ferreira, j. 12.11.2013

STJ, AgRg no AREsp 426.951/PR, Rel. Min. Luis Felipe Salomão, j. 03.12.2013

STJ, REsp 1.326.445/PR, Rel. Min. Nancy Andrighi, j. 04.02.2014

STJ, REsp 1.159.317/SP, Rel. Min. Ricardo Villas Bôas Cueva, j. 11.03.2014

STJ, AgRg no AREsp 477.387/DF, Rel. Min. Raul Araújo, j. 21.10.2014

STJ, EDcl no AgRg no REsp 1.436.833/RS, Rel. Min. Sidnei Beneti, rel. p/ acórdão Min. Paulo de Tarso Sanseverino, j. 02.12.2014

STJ, AgRg no REsp 1.485.344/SP, Rel. Min. Marco Aurelio Bellizze, j. 05.02.15

STJ, AgRg no REsp 1.516.891/RS, Rel. Min. Humberto Martins, j. 28.04.2015

STJ, AgRg no Ag 1.327.784/ES, Rel. Min. Maria Isabel Gallotti, j. 27.08.2013

STJ, AgRg no AREsp 431.493/PR, Rel. Min. Sidnei Beneti, j. 27.3.2014

STJ, AgRg no REsp 1.317.745/SP, Rel. Min. Paulo de Tarso Sanseverino, j. 06.05.2014

STJ, AgRg no AREsp 507.061/PE, Rel. Min. Sidnei Beneti, j. 5.8.2014

STJ, AgRg no REsp 1.411.828/RJ, Rel. Min. Nancy Andrighi, j. 07.08.2014

STJ, REsp 1.296.849/MG, Rel. Mina. Maria Isabel Gallotti, j. 14.2.2017

TJDFT, Embargos Infringentes na apelação cível n. 42.630-97, Rel. Desa. Vera Lúcia Andrighi, j. 4.3.1998

TJDFT, apelação cível n. 20060910157468, Des. Rel. Humberto Adjuto Ulhôa, j. 1.6.2009

TJDFT na apelação n. 0120673-43.2006.8.07.0001, Rel. Desa. Nídia Corrêa Lima, j. 12.5.2010

TJMG, apelação cível n. 1.0024.02.884407-4/001, Des. Rel. Antônio Bispo, j. 11.4.2013

TJPR, apelação n. 65244-0, Rel. Des. Accácio Cambi, j. 2.9.1998 
TJPR, apelação n. 163145-6, Rel. Des. Jurandyr Souza Junior, j. 23.5.2001

TJPR, apelação n. 145468-6, Rel. Des. Celso Rotoli de Macedo, j. 22.10.2003

TJPR, apelação n. 481728-9, Rel. Des. Ruy Francisco Thomaz, j. 8.7.2008

TJPR, apelação n. 740451-3, Rel. Des. Jucimar Novochadlo, j. 16.2.2011

TJPR, apelação n. 1307727-1, Rel. Des. Roberto Portugal Bacellar, j. 11.8.2015

TJPR, apelação n. 1439144-1, Rel. Des. Victor Martim Batschke, j. 15.3.2016

TJRJ, apelação cível n. 0076149-06.1998.8.19.0001, Des. Rel. Mauro Fonseca Pinto Nogueira, j. 3.10.2000

TJRJ, apelação n. 0421912-05.2008.8.19.0001, Rel. Desa. Nanci Mahfuz, j. 30.6.2011

TJRJ, apelação n. 0094454-18.2010.8.19.0001, Rel. Des. Juarez Fernandes Folhez, j. 13.5.2015

TJRJ, apelação n. 0083459-69.2012.8.19.0002, Rel. Des. André Ribeiro, j. 7.3.2017

TJRS, apelação n. 500400502, Rel. Des. Arnaldo Rizzardo, j. 13.9.1989

TJRS, Apelação n. 70022049811, Rel. Des. Paulo Antônio Kretzmann, j. 27.3.2008

TJRS apelação n. 0281253-65.2013.8.21.700, Rel. Des. Jorge Luiz Lopes do Canto, j. 30.10 .2013

TJRS, apelação n. 70061122438, Rel. Desa. Isabel Dias Almeida, j. 27.8.2014

TJRS, apelação n. 0310950-29.2016.8.21.70000, Rel. Des. Alex Gonzaga Custodio, j. 26.10.2017

TJSC, apelação n. 1988.092116-3, Rel. Des. Newton Janke, j. 21.11.2002

TJSC, apelação n. 2005.026559-1, Rel. Des. Carlos Adilson Silva, j. 29.9.2009

TJSC, apelação n. 2007.041682-6, Rel. Des. Altamiro de Oliveira, j. 13.12.2011

TJSC, apelação n. 2013.033641-7, Rel. Des. Guilherme Nunes Born, j. 20.3.2014 
TJSP, agravo de instrumento n. 9093373-40.1997.8.26.0000, Rel. Des. Cunha Cintra, j. 5.2.1999

TJSP, agravo de instrumento n. 9112921-80.1999.8.26.0000, Rel. Des. Jacobina Rabello, j. 9.5.2002

TJSP, agravo de instrumento 9084320-30.2000.8.26.0000, Rel. Des. Antonio Maria, j. 25.4.2006

TJSP, agravo de instrumento n. 9098263-17.2000.8.26.0000, Rel. Des. Magno Araújo, j. 11.5.2006

TJSP, agravo de instrumento n. 9166110-60.2005.8.26.0000, Rel. Desa. Cristina Zucchi, j. 14.2.2007

TJSP, apelação n. 994.03.101754-7, Rel. Des. Sebastião Carlos Garcia, j. 15.4.2010

TJSP, apelação n. 9095804-71.2002.8.26.0000, Rel. Des. Sebastião Carlos Garcia, j. 15.9.2011

TJSP, apelação n. 0114695-80.2008.8.26.0003-00, Rel. Des. Elcio Trujillo, j. 26.10.2011

TJSP, apelação n. 0265801-26.2007.8.26.0100, Rel. Des. Enio Zuliani, j. 10.4.2012

TJSP, apelação n. 0015939-21.2009.8.26.0223, Rel. Des. Maia da Cunha, j. 31.7.2012

TJSP, apelação n. 0341976-02.2009.8.26.0000, Rel. Des. Ribeiro da Silva, j. 5.9.2012

TJSP, apelação n. 0005976-32.2003.8.26.0309, Rel. Des. Ricardo Negrão, j. 16.10.2012

TJSP, apelação n. 0007092-28.2006.8.26.0581, Rel. Des. Francisco Loureiro, j. 30.10.2012

TJSP, apelação cível n.0000111-94.2009.8.26.0025, Rel. Des. Helio Faria, j. 30.1.2013

TJSP, apelação n. 0000108-24.1998.8.26.0091, Rel. Des. Teixeira Leite, j. 12.3.2013

TJSP, apelação n. 0279546-14.2009.8.26.0000, Rel. Des. Fábio Quadros, j. 16.5.2013

TJSP, apelação n. 0009169-58.2008.8.26.0510, Rel. Des. Miguel Brandi, j. 11.9.2013

TJSP, apelação n. 9103353-25.2008.8.26.0000, Rel. Des. José Joaquim dos Santos, j. 26.11.2013 
TJSP, apelação n. 0106819-35.2012.8.26.0100, Rel. Des. Mario Chiuvite Junior, j. 9.4.2014

TJSP, apelação n. 0185809-45.2009.8.26.0100, Rel. Des. Fortes Barbosa, j. 11.9.2014 TJSP, apelação n. 0013989-08.2012.8.26.0114, Rel. Des. Francisco Loureiro, j. 4.11.2014 TJSP, apelação n. 1000413-90.2014.8.26.0006, Rel. Des. Maia da Cunha, j. 4.11.2014 TJSP, apelação n. 1001884-69.2014.8.26.0224, Rel. Des. Tasso Duarte de Melo, j. 11.2.2015

TJSP, apelação n. 1000310-46.2014.8.26.0568 Rel. Des. Thiago de Siqueira, j. 25.2.2015 TJSP, apelação n. 9000018-10.2010.8.26.0003, Rel. Des. Fortes Barbosa, j. 8.4.2015 TJSP, apelação n. 0010774-27.2010.8.26.0362, Rel. Des. Francisco Loureiro, j. 9.4.2015 TJSP, apelação n. 0100281-14.2007.8.26.0003, Rel. Des. Piva Rodrigues, j. 14.4.2015 TJSP, apelação n. 0035752-36.2010.8.26.0114, Rel. Des. Francisco Loureiro, j. 6.5.2015 TJSP, apelação n. 0028127.-04.2010.8.26.0161, Rel. Des. José Aparício Coelho Prado Neto, j. 22.5.2015

TJSP, apelação n. 0003116-89.2009.8.26.0360, Rel. Des. Fortes Barbosa, j. 29.7.2015 TJSP, apelação n. 0005025-55.2010.8.26.0224, Rel. Des. Pereira Calças, j. 29.7.2015 TJSP, apelação n. 1008341-73.2014.8.26.0562, Rel. Des. Pereira Calças, j. 30.9.2015 TJSP, apelação n. 0018750-35.2009.8.26.0099, Rel. Des. Ricardo Negrão, j. 6.4.2016 TJSP, apelação n. 1011488-72.2013.8.26.0100, Rel. Des. Enio Zuliani, j. 14.6.2016 TJSP, apelação n. 0010622-35.2010.8.26.0020, Rel. Des. Francisco Loureiro, j. 22.6.2016 TJSP, apelação n. 0040958-31.2010.8.26.0114, Rel. Des. Fabio Tabosa, j. 27.6.2016 TJSP, apelação cível n. 0020052-53.2013.8.26.0554, Rel. Des. Hamid Bdine, j. 22.2.2017 TJSP, apelação n. 1066058-37.2015.8.26.0100, Rel. Des. Hamid Bdine, j. 15.3.2017 TJSP, apelação n. 1015045-26.2015.8.26.0576, Rel. Des. Teixeira Leite, j. 29.3.2017 
TJSP, apelação n. 1004049-78.2016.8.26.0011, Rel. Des. Cesar Ciampolini, j. 4.10.2017

\section{ESTADOS UNIDOS}

Ainger v. Mich. Gen. Corp., 476 F. Supp. 1209, 1225 (S.D.N.Y. 1979)

American Transtech Inc. v. U.S. Trust Corp., 933 F. Supp. 1193 (S.D.N.Y. 1996)

Bahre v. Pearl, 595 A.2d 1027, 16 U.C.C. Rep. Serv. 2d 780 (Me. 1991)

Blasingame v. American Materials, Inc., 654 S.W.2d 659, 35 U.C.C. Rep. Serv., 1610 (Tenn. 1983)

Cambron v. Moyer, 519, N.W.2d 381, 25 U.C.C. Rep. Serv. 2d 218 (Iowa 1994)

CBS v. Ziff-Davis Publishing g Co., 553 N.E.2d 997, 1001 (N.Y. 1990)

Consult Urban Renewal Dev. Corp. v. T.R. Arnold \& Assoc., Inc., CIV A 06-1684 WJM, 2007 WL 1175742 (D.N.J. Apr. 19, 2007)

Crofton ventures Ltd. Partnership v. G\&H Partnership, 116 F. Supp. 2d 633 (D. Md. 2000)

DCV Holdings, Inc. v. ConAgra, Inc. 889 A.2d 954 (Del. 2005)

Edwin Bender \& Sons v. Ericson Livestock Commission Co., 421 N.W.2d 766 (Neb. 1988)

Gloucester Holding Corp. v. US Tape \& Sticky Products, LLC, 832 A2d 116 (Del. Ch. 2003)

Great Lakes Chemical Corp. v. Pharmacia Corp. 788 A.2d, 544 (Del. Ch. 2001)

Grupo Condumex, SA v. SPX Corporation unpublished opinion and order of the US District Court for the ND of Ohio, issued September 19, 2008 (Docket No. 3:99CV7316) (aplicando a lei do estado de Michigan)

Gusmao v GMT Group, Inc., 06 Civ. 5113 (GEL) (S.D.N.Y. Aug. 1, 2008) 
Hecht v. Components Int'1, Inc., 867 N.Y.S.2d 889, 895-96 (Sup. Ct. 2008)

Hoffer v. Callister, 47 P.3d 1261 (Idaho 2002)

IBP, Inc. v. Tyson Foods, Inc. 789 A.2d 14 (Del. Ch. 2001)

In re Marriage of Ginsberg, 750 N.W.2d 520, 522 (Iowa 2008)

Interim Healthcare, Inc. v. Spherion Corporation 884 A.2d 513 (Del. Super. Ct. 2005)

Jackson v. Russell, 498 N.E.2d 22 (Ind. Ct. App. 1986)

Jennison v. Jennison, 346 Pa. Super. 47, 99 A.2d 302, 41 U.C.C. Rep. Serv. 585 (1985)

Kazerouni v. De Satnick, 279 Cal. Rptr. 74, 75-76 (Cal. Ct. App. 1991)

Lightning Litho, Inc. v. Danka Indus., Inc., 776 N.E.2d 1238, 1241-1242 (Ind. Ct. App. 2002)

Majkowski v. American Imaging Management, LLC, 913 A.2d 572, 588-89 (Del. Ch. 2006)

Ferd S. Meyer and Hoke T. Maroon v. Seabord Finance Company, 309 F.2d 741 (5th Circ. 1962)

Newman v. Kendall 103 Vt 421 (Vt. 1931)

Paniaguas v. Aldon Companies, Inc., 2:04-CV-468-PRC, 2006 WL 2788585 (N.D. Ind. Sept. 26, 2006)

Pegasus Management Co., Inc. v. Lyssa, Inc., 995 F. Supp. 29 (D. Mass. 1998)

Queen Villas Homeowners Association v. TCB Property Management, 56 Cal. Rptr. 3d 528, 534 (Cal. Ct. App. 2007)

Reno v. Bull, 124 N.E. 144, 146 (N.Y. 1919)

Rhode Island Hosp. v. Collins, 117 R.I. 535, 368 A.2d 1225, 21 U.C.C. Rep. Serv. 619 (1977)

Rocky Mountain Helicopters, Inc. v. Air Freight, Inc., 773, P.2d 911 (Wyo. 1989)

SEC vs. Texas Gulf Sulfur Co., 401 F.2d 833 (2d Cir. 1968) 
Shippen v. Bowen, 122 U.S. 575, 581, 7 S. Ct. 1283, 30 L. Ed. 1171 (1887)

Smith v. Tennessee Furniture Industries, Inc., 212, Tenn. 291, 369 S.W.2d 721 (Tenn. 1963)

Specialized Tours, Inc. v. Hagen 392 N.W.2d 520 (Minn. 1986)

SpinCycle, Inc. v. Kalender, 186 F. Supp. 2d 585, 588-89 (D. Md. 2002)

Stevenson v. B.B. Kirkland Seed Co., 180 S.E. 197, 200 (S.C. 1935)

Telephia, Inc. v. Cuppy, 411 F. Supp. 2d 1178, 1188 (N.D. Cal. 2006)

United Ind. Ins. Agencies Inc. v. Bank of Honolulu, 6 Hawaii App. 222, 718 P.2d 1097, 1 U.C.C. Rep. Serv. 2d 866 (1986)

\section{FRANÇA}

Cass. com. 12 décembre 1972, pourvoi n. 71-11080

Cass. Com. 20 février 1979, Gaz. Pal. 1979-1, I pan. 246

Cass. Com. 3 avril 1979, Revue des Sociétés, 1980, p. 723

Cass. com. 25 janvier 1983, pourvoi n. 81-13085

Cass. com. 21 mars 1983, Bull. Joly 1983, § 213, p. 510

Cass. Civ. 3eme, 25 janvier 1989, Bull. III, n. 20

Cass. Com. 19 déc. 1989, pourvoi n. 88-15335

Cass. com. 23 janvier 1990, pourvoi n. 87-17521

Cass. Civ. 27 mars 1991, Bull. III, n. 107

Cass. Com. 1er octobre 1991, pourvoi 89-13967

Cass. Civ. 23 octobre 1991, Bull. III, n. 249

Cass. com. 5 juillet 1994, Bull. Joly 1994, p. 1222 
Cass. Com. 17 octobre 1995, pourvoi 93-20523

Cass. Com. 12 décembre 1995, pourvoi n. 91-21304

Cass. Com. 18 février 1997, pourvoi n. 95-12617

Cass. Com. 21 oct. 1997, pourvoi n. 95-18077

Cass. Com. 7 oct. 1997, pourvoi n. 95-18119

Cass. Com. 3 février 2015, pourvoi n. 13-12483

Montpellier, 24 oct. 1981, JCP (E) 1991.112, obs. A. Viandier et J.-J. Caussain, n. 12

\section{INGLATERRA}

Anderson \& Sons Ltd. v. Rhodes (Liverpool) Ltd. [1967] 2 All E.R. 850

Bunge Corp v. Tradax Export SA [1981] 1 W. L. R. 711

Central London Property Trust Ltd. v. High Trees House Ltd. [1947] KB 130

Derry v. Peek (1889) 14 App Cas 337

Dick Bentley Productions Ltd. v. Harold Smith (Motors) Ltd. [1965] 1 WLR 623

Esso Petroleum Co Ltd. v. Mardon [1976] Q. B. 801

Eurocopy v. Teesdale [1992] BCLC 1067, CA

Hedley Byrne \& Co Ltd. v. Heller \& Partners Ltd. [1964] A. C. 465

Hongkong Fir Shipping Co Ltd. v. Kawasaki Kisen Kaisha Ltd. [1962] 2 Q. B. 26

Infiniteland Ltd. v. Artisan Contracting Ltd. [2004] EWHC 955 (Ch)

Jacobs v. Batavia [1924] 1 Ch 287

Jorden v. Money [1854] 5 HL Cas 185

Lombard North Central plc v. Butterworth [1987] Q. B. 527 
Oscar Chess Ltd. v. Williams [1957] 1 WLR 370

United Scientific Holdings v. Burnley BC [1978] A. C. 904

Walford v. Miles [1992] 2 A.C. 128 [1992] 1 All E.R. 453 (HL)

\section{ITÁLIA}

App. Milano, 13 aprile 1951

App. Roma, 21 luglio 1933

Cass. 28 agosto 1952, n. 2784

Cass., 10 febbraio 1967, n. 338 (62)

Cass. 10 febbraio 1987, n. 721

Cass. 29 agosto 1991 n. 9227

Cass. 19 luglio 2007, n. 16031

Cass. 26 luglio 2014, n. 16963 